PATRÍCIA DE LUCA VITALLI

\title{
ANÁLISE DOS ASPECTOS JURÍDICOS CORRELATOS À ZONA DE AMORTECIMENTO DE UNIDADES DE CONSERVAÇÃO: ESTUDO DE CASO DA ESTAÇÃO ECOLÓGICA DE ASSIS (SP)
}

\author{
Dissertação apresentada à Escola de \\ Engenharia de São Carlos da Universidade \\ de São Paulo, como parte dos requisitos para \\ a obtenção do Título de Mestre em Ciências \\ da Engenharia Ambiental. \\ Orientador: Dra. Giselda Durigan
}

São Carlos

2007 



\section{DEDICATÓRIA}

Dedico esta pesquisa aos meus pais Célia e Wilson que mesmo não compreendendo muitas vezes o que eu faço sempre me deram amor e apoio incondicionais. 


\section{AGRADECIMENTOS}

À Doutora Giselda Durigan (Gi), agradeço a oportunidade, apoio e a iniciativa de aceitar o desafio proposto pela ciência ambiental (exercício da interdisciplinaridade) ao orientar uma profissional de área tão diferente. Minha admiração e carinho enquanto pesquisadora e pessoa que muito me ensinou neste tempo em que caminhamos junto;

Ao CNPq, pela concessão da bolsa de estudo, viabilizando a conclusão desta pesquisa;

Ao Instituto Florestal subordinado a Secretaria do Meio Ambiente do Estado de São Paulo, em permitir e proporcionar a realização deste estudo e aos profissionais que trabalham na unidade de Assis pela amizade, acolhida e auxílio que muito contribuíram para a construção dessa dissertação: Honda, Josi, Vivi, Wilson, Marisa, Fátima, Neide, Max, Adriano, Karine, Silvana, Melo, Osmar;

Ao DEPRN que concedeu a autorização para a realização da pesquisa;

Aos órgãos institucionais que concederam as entrevistas: DEPRN (Supervisor Regional Edson Ambrósio); Polícia Militar Ambiental (Sargento Antônio Cruz Gonçalves); Prefeitura Municipal de Assis, nas pessoas de Nilsa Ferreira da Silva (Chefe do Parque de Reciclagem e Compostagem de Lixo), Sonia Rodrigues Spera (Assessora responsável pela elaboração do Plano Diretor Municipal) e a Moisés Jubran (Chefe de Gabinete da Secretária de Indústria e Comércio responsável pelo Distrito Industrial);

Ao Ministério Público Estadual na pessoa do Promotor Dr. Carlos Henrique A. Rinard, que mesmo não concedendo a entrevista respondeu as questões por e-mail;

A Maria José Brito Zakia (ZeZé) pela co-orientação prestada durante toda a pesquisa e pelos apontamentos preciosos que nortearam todo o estudo;

Aos professores da banca do exame da qualificação, Zezé e Victor Ranieri pelas 
recomendações fundamentais para a condução e conclusão do trabalho;

Ao Prof. Dr. Marcelo pelas valiosas contribuições para a concretização da pesquisa;

Ao Coordenador do Programa Prof. Dr. Marcelo Pereira de Souza, e a todos os funcionários da unidade em especial a Claudete secretária do Programa;

Em especial ao Julio, pelo amor, carinho, companheirismo, apoio e que me ensinou a andar de mãos dadas durante esta empreitada;

Aos meus queridos e grandes amigos que estiveram presente durante este trajeto: Clarinha, Cremis, Dani, Eriquinha, Fernanda, Gil, Juliana, Juliano, Larinha, Luiza, Luis, Maria Luiza, Marcelo, Regiane, Tata,Vivi, Yuri e Cleo pelas trocas e discussões que enriqueceram esta pesquisa e pelos momentos de alegria que serão inesquecíveis e marcarão para sempre a minha vida. 
"A injustiça que se faz a um é uma ameaça que se faz a todos".

Charles Louis de Secondat, Barão de Montesquieu (filósofo francês).

"Se as cidades forem destruídas e os campos forem conservados, as cidades ressurgirão. Se queimarem os campos e conservarem as cidades estas não sobreviverão”.

Benjamim Franklin 


\section{RESUMO}

VITALLI, P.D.L. (2007). Análise dos aspectos jurídicos correlatos à Zona de Amortecimento de unidades de conservação: estudo de caso da Estação Ecológica de Assis (SP). Dissertação (Mestrado) - Escola de Engenharia de São Carlos, Universidade de São Paulo, São Carlos, 2007. As figuras das Zonas de Entorno e de Amortecimento de unidades de conservação foram criadas em lei como áreas submetidas a limitações administrativas, nas quais devem ser impedidas ou regulamentadas atividades que ofereçam ameaça aos recursos naturais dos ecossistemas protegidos. A eficácia desses instrumentos jurídicos, porém, é discutível e foi objeto do presente estudo, tratando de um estudo de caso, na Estação Ecológica de Assis, situada no sudoeste do Estado de São Paulo, enquadrada como Unidade de Proteção Integral, pertencente ao Instituto Florestal, órgão este subordinado à Secretaria de Estado Meio Ambiente. O estudo foi realizado com os seguintes objetivos: 1) proceder análise da legislação que trata do assunto, para tornar clara a natureza jurídica da Zona de Entorno e Zona de Amortecimento de unidades de conservação; 2) identificar as atividades humanas impactantes já existentes na Zona de Entorno da Estação Ecológica de Assis, hierarquizá-las segundo o nível de ameaça que oferecem e apontar possíveis soluções; 3) avaliar a eficácia da norma que estabelece o procedimento licenciatório em, efetivamente, impedir que sejam instaladas novas obras ou atividades impactantes na Zona de Entorno da EEcA. O levantamento das ameaças baseou-se em diagnóstico pré-existente, desenvolvido quando da elaboração do Plano de Desenvolvimento Sustentável para o Entorno da EEcA. No presente estudo, foi desenvolvido um protocolo de avaliação dos diferentes tipos de atividades impactantes, visando hierarquizá-las quanto ao nível de ameaça e possibilidade de solução, como ferramenta para dar suporte à ação dos gestores da unidade. Para as ameaças mais importantes (expansão urbana, aterro sanitário, expansão agrícola, animais exóticos e depósito de entulho) foram analisados os instrumentos jurídicos correlatos e verificou-se que, na maioria dos casos, a falha está, apenas, na aplicação das leis. Analisou-se, ainda, especificamente, a eficácia da Resolução CONAMA 13/90, que dispõe sobre a obrigatoriedade de que os gestores das unidades de conservação sejam ouvidos nos processos de licenciamento ambiental dentro da Zona de Entorno de unidades de conservação de Proteção Integral. Foram analisados 155 processos de licenciamento de obras inseridas na Zona de Entorno da EEcA. Concluiu-se que os pedidos mais freqüentes tratam de corte de árvores isoladas (35,5\%) e intervenção em Área de Preservação Permanente (31\%), ambos relacionados com a expansão agrícola, sendo que os gestores da unidade foram ouvidos em apenas $8 \%$ desses processos. A lei não é clara quanto à especificação do que venha a ser 'atividade potencialmente impactante para efeito da Resolução CONAMA 13/90 e este é o pressuposto para que o órgão gestor tenha de ser ouvido nos processos. Esta indicação deveria ser feita pelo órgão gestor, mas, no caso da Estação Ecológica de Assis é inexistente, ficando a decisão por conta do órgão licenciador. Conclui-se que, no caso da $\mathrm{EEcA}$, os instrumentos jurídicos vigentes não têm sido suficientes para conter os impactos oriundos da vizinhança sobre os recursos naturais da unidade de conservação. A Zona de Entorno, para funcionar, de fato, como um anteparo às atividades que ofereçam ameaça aos ecossistemas naturais e ao desenvolvimento sustentável, depende de providências que transcendem a esfera jurídica, passando pela conscientização das comunidades do entorno e, sobretudo, pela consolidação da sua existência perante os órgãos que atuam no licenciamento e fiscalização ambiental ou na tomada de decisões sobre o ordenamento territorial do município.

Palavras-chave: Áreas especialmente protegidas. Licenciamento ambiental. Resolução CONAMA 13/90. SNUC. Zona tampão. 


\begin{abstract}
VITALLI, P.D.L. (2007). Legal aspects regarding the buffer zone of protected áreas: case study of Assis Ecological Station (São Paulo State, Brazil). MsC (Dissertation) - Escola de Engenharia de São Carlos, Universidade de São Paulo, São Carlos, 2007.

Buffer Zones of the natural reserves have been considered as the most powerful instrument to prevent environmental impacts to the ecosystems coming from the neighboring areas. Their efficacy, however, is controvertible and that was the subject of the present case study, concerning to Assis Ecological Station, an integrally protected reserve from the Forestry Institute (Environment Secretary of São Paulo State). The aims of the study were: 1) to analyze the existing juridical tools concerning to the buffer zone of natural reserves; 2) to diagnose the anthropic activities already existing in the buffer zone of Assis Ecological Station, and to hierarchize them according to their threat level and possibility of solution; 2) to analyze the legal instruments dealing with these threats, searching for possible gaps and conflicts; 3 ) to evaluate the efficacy of Resolution CONAMA 13/90 in preventing new impactant activities to be installed in the buffer zone of Assis Ecological Station. Impactant activities already existing, which had been previously diagnosed by the Sustainable Development Plan for Assis Ecological Station Buffer Zone, were hierarchized according to their threat level and possibility of solution by means of management actions. To the five more important threats (urban expansion, landfill, agriculture expansion, animal invaders and refuse material disposal), the correlated legislation was analyzed. For most cases the existing lows are just not executed. To verify the efficacy of Resolution CONAMA 13/90, a total of 155 lawsuits were analyzed. The most frequent impact to the natural resources has been related to the conversion of pastures into agriculture $(35.5 \%$ cutting trees requested and $31 \%$ concerning the riparian zone reforestation, which is obliged). Against the law, only $8 \%$ of the lawsuits were submitted to the managers of the protected area and, from those which were submitted, in most cases, the opinion of the managers did not change the final sentence. The law is not clear in classifying a required undertaking as "potentially impactant or not" and that is supposed to be the prime condition to be mandatory the manager's opinion. We consider that the existing juridical instruments stating the buffer zone have not been sufficient to prevent environmental impacts to the natural resources of the protected areas. Prevention depends on environmental education of the neighboring communities, and also reinforcement of the buffer zone existence before environmental licensing and inspection agents or decision makers working on territorial ordainment in the municipalities.
\end{abstract}

Keywords: Buffer zone. Environmental legislation. Environmental licensing. Natural reserves. 


\section{LISTA DE SIGLAS}

ABNT - Associação Brasileira de Normas Técnicas

ADI - Ação Direta de Inconstitucionalidade

APP - Área de Preservação Permanente

APA - Área de Proteção Ambiental

CC - Código Civil

CF - Constituição Federal

CETESB - Companhia de Tecnologia e Saneamento Ambiental

CNPq - Conselho Nacional de Desenvolvimento Científico e Tecnológico

COMDEMA - Conselho Municipal de Defesa do Meio Ambiente

CONAMA - Conselho Nacional do Meio Ambiente

CONSEMA - Conselho Estadual do Meio Ambiente

CTN - Código Tributário Nacional

DEPRN - Departamento de Proteção dos Recursos Naturais

DRPE/IF - Divisão de Reservas e Parques Estaduais do Instituto Florestal

EEcA - Estação Ecológica de Assis

FAO - Food and Agriculture Organization of the United Nation

FEA - Floresta Estadual de Assis

IBAMA - Instituto Brasileiro do Meio Ambiente e dos Recursos Naturais Renováveis

IF - Instituto Florestal

IUCN - União Internacional para a Conservação da Natureza

MP - Ministério Público

MMA - Ministério do Meio Ambiente

SMA - Secretaria de Meio Ambiente

SNUC - Sistema Nacional de Unidades de Conservação

STF - Supremo Tribunal Federal

UC - Unidade de Conservação

UHE - Usina Hidroelétrica

UNESCO - United Nations Educational, Scientific and Cultural Organization

WWF - World Wildlife Fund 


\section{SUMÁRIO}

RESUMO

ABSTRACT

INTRODUÇÃ

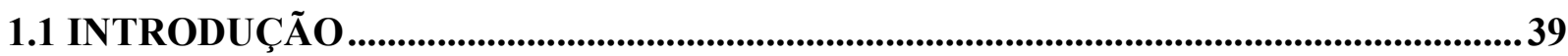

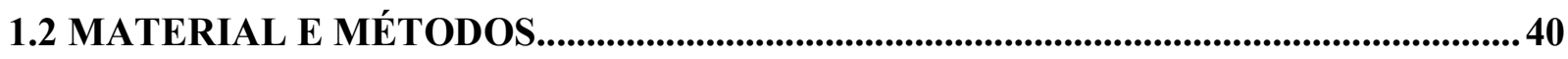

1.2.1 LOCAL DE ESTUDO ..............................................................................................................40

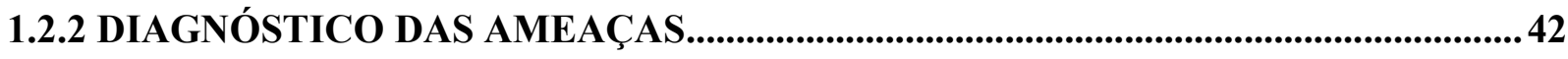

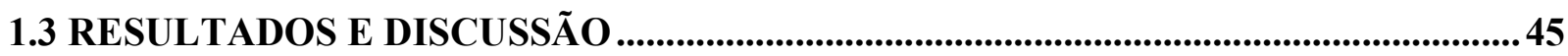

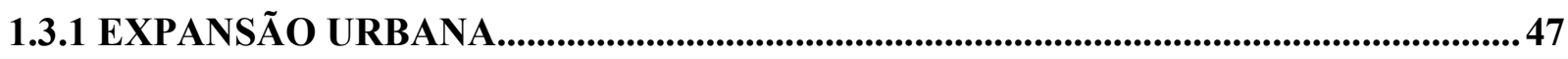

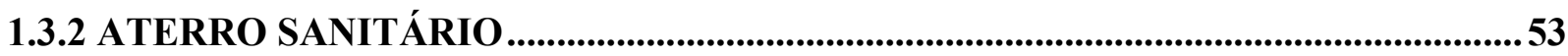

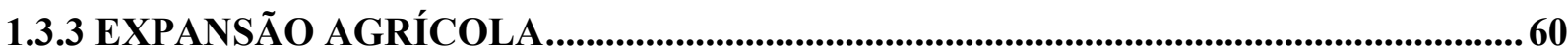

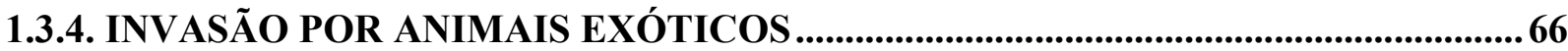

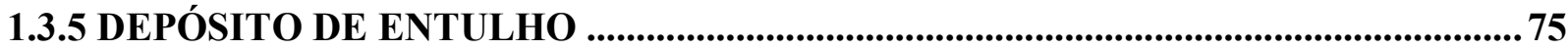

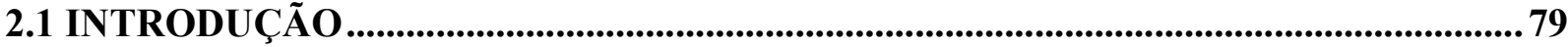

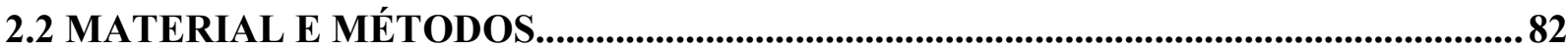

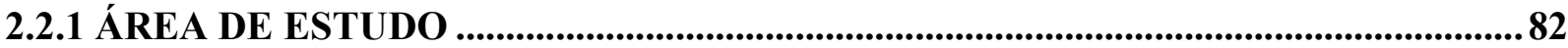

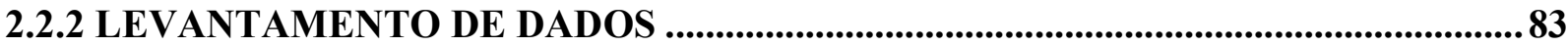

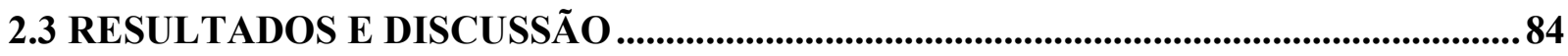

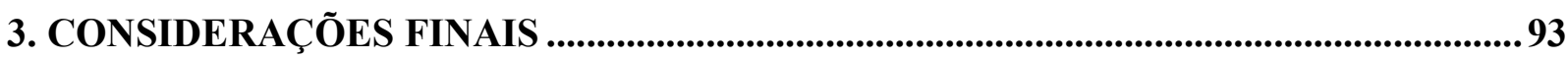

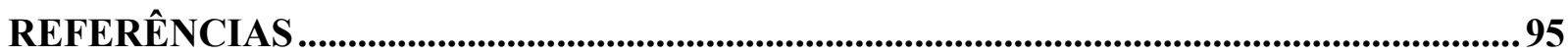

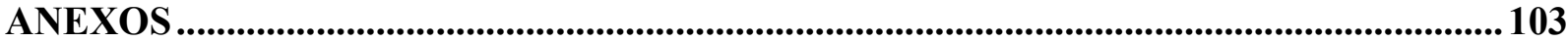





\section{INTRODUÇÃO}

A grande pressão que as atividades humanas extrativistas exercem sobre os hábitats representa uma grave ameaça à preservação e conservação das espécies. As perturbações humanas em série têm sido responsáveis pela destruição de diversos biomas, levando à destruição da paisagem e, com isso, acarretando o desequilíbrio entre as espécies (BEALE; MONAGHAN, 2004). Diversos autores têm estudado a perda da diversidade biológica (BOWMAN, 1998; FORESTER; MACHLIS, 1996; PRIMACK; RODRIGUES, 2001; SAUNDERS; HOBBS; MARGULES, 1991; WILSON, 1997), que é um dos resultados mais desastrosos da destruição dos ambientes naturais.

Segundo Dias (2001), biodiversidade é conceituada pela Convenção sobre Diversidade Biológica (Decreto Legislativo 2-94/Artigo $2^{\circ}$ - BRASIL, 1994) como sendo:

a variabilidade de organismos vivos de todas as origens, compreendendo, dentre outros, os ecossistemas terrestres, marinhos e outros ecossistemas aquáticos e os complexos ecológicos de que fazem parte; compreendendo ainda a diversidade dentro de espécies e de ecossistemas .

O Sistema Nacional de Unidades de Conservação incorporou o conceito definido pela Convenção em seu artigo. $2^{\circ}$, inciso III, da Lei nº. 9.985/00 (PINTO; WINDT; SIQUEIRA, 2001).

Ocorre que os distúrbios antrópicos são causados pelo maior consumo dos recursos naturais em face ao crescimento populacional desenfreado. Neste sentido, Wilson (1997) relaciona o crescimento explosivo das populações humanas com o desgaste ambiental empreendido de forma acelerada, especialmente nos países tropicais.

O ambiente natural fornece recursos economicamente valiosos, tais como: alimentos, medicamentos, recursos in natura, matérias-primas e fontes de energia. Além disso, os sistemas 
biológicos prestam serviços ambientais importantes para o ser humano (BOWMAN, 1998; DIAS, 2001).

Uma das maneiras de amenizar os riscos potenciais causados pelas atividades humanas, que ameaçam a conservação da biodiversidade, tem sido a criação das áreas protegidas. Essas áreas têm a finalidade de preservar partes representativas dos ecossistemas, sua biodiversidade e processos ecológicos.

O embrião do conceito de unidade de conservação surgiu em 1872 nos Estados Unidos, com a criação do Parque Nacional de Yellowstone. Nessa ocasião, as áreas protegidas desempenhavam exclusivamente a função de proteção dos monumentos naturais e das belezas cênicas existentes na natureza (BRITO, 2003).

A importação de um modelo concebido em outro contexto ambiental, social, econômico e político tem sido alvo de muitas críticas. Para Diegues (2004), a criação de parques e reservas tem sido uma das principais estratégias para a conservação da natureza, sendo uma das políticas conservacionistas mais utilizadas pelos países do terceiro mundo. Por isso, o modelo conservacionista deve ser desenhado em função das peculiaridades de cada país, ainda que seja conveniente a existência de organismos internacionais que integrem as iniciativas dos diferentes países e possibilitem o estabelecimento de estratégias mundiais para a conservação.

As primeiras Convenções Internacionais relacionadas à temática ambiental não tiveram como preocupação a conservação da diversidade biológica, mas sim a proteção das belezas cênicas naturais. Nessa linha de pensamento, foi estabelecida a Convenção para a Preservação da Fauna e Flora em seu Estado Natural, realizada em Londres (1933), que estabeleceu novas disposições para os Parques Nacionais (BRITO, 2003).

O Brasil participou dessa Convenção e, inserido na filosofia conservacionista pregada mundialmente, instituiu o Código Florestal Brasileiro - Decreto Federal nº . 23.793/34 (BRASIL, 
1934). Pouco tempo depois deu início à criação de unidades de conservação, sendo os primeiros Parques Nacionais brasileiros: Itatiaia, em 1937, Serra dos Órgãos e Iguaçu em 1939. Desde então foi criado um grande número de unidades de conservação no país e fortaleceram-se as políticas voltadas à criação e gestão de unidades de conservação.

A proteção legal das unidades de conservação no Brasil avançou com o Novo Código Florestal - Lei $\mathrm{n}^{\mathrm{o}} .4771$, de 1965 (BRASIL, 1965), nos arts. $5^{\circ}$ e $6^{\circ}$, que posteriormente foram revogados pelo art. 60 da Lei nº. 9.985/00 - SNUC (PINTO; WINDT; SIQUEIRA, 2001).

Apesar dos avanços na legislação e da gradativa expansão do sistema Nacional de Unidades de Conservação, crescia no Brasil, da mesma forma como em outras partes do mundo, a percepção de que atividades desenvolvidas ao redor das áreas protegidas poderiam colocar em risco os ecossistemas, sendo necessárias medidas adicionais visando à sua efetiva conservação. Desde 1986, a União Internacional para a Conservação da Natureza (UICN) tem se posicionado de forma crítica contra o tratamento das unidades de conservação como "ilhas" (DIEGUES, 2004).

A partir da constatação de que a criação de áreas protegidas não bastava para a preservação e conservação do hábitat, avançou-se para o consenso de que seria preciso tomar providências para minimizar os impactos negativos que o ambiente externo exerce sobre as áreas protegidas. Fortaleceu-se, entre os conservacionistas e tomadores de decisão, a idéia de que as áreas protegidas deveriam ter um filtro que impedisse que as atividades antrópicas externas prejudicassem os ecossistemas naturais dentro de seus limites. O filtro seria uma das práticas conservacionistas a ser incorporadas pelas unidades de conservação.

Um exemplo dessa prática conservacionista é o adotado na Suíça. Nesse país as reservas são pequenas e as populações animais e vegetais encontram-se isoladas. Tais reservas são vulneráveis aos distúrbios naturais e decorrentes da ação humana (agricultura, silvicultura e 
crescimento urbano). Como observado por Götmark, Söderlundh e Thorell (2000), a forma encontrada de melhorar o tamanho ou reduzir a vulnerabilidade dessas reservas foi criar, ao seu redor, zonas tampão, onde o uso da terra é regulado para proteger a área nuclear. Analisando aspectos relativos a unidades de conservação na Suíça, esses autores observam que zonas tampão são parte de uma estratégia para o zoneamento das reservas da biosfera, onde os alvos principais são a proteção da biodiversidade e a participação das populações locais no uso sustentável da Terra. Segundo a United Nations Educational, Scientific and Cultural Organization (UNESCO, 1996), poucos estudos testaram sua utilidade para outras categorias de unidades de conservação já existentes. Por isso, a estratégia adotada na Suíça tem sido a adição de novas reservas nas proximidades de reservas já existentes, com resultado melhor do que as zonas tampão. Para os mesmos autores, um componente importante das zonas tampão é o proprietário privado, aquele que pode ser afetado pela regulamentação do uso da terra. Naquele país, portanto, utilizam-se duas alternativas de proteção para a zona tampão: (1) compra das terras pelo Estado, e (2) compensação econômica aos proprietários de terra privados que aplicam medidas conservacionistas.

A função principal desempenhada pelas zonas tampão é ampliar a presença, ao redor das unidades de conservação, de hábitats favoráveis à vida silvestre, assegurando, com isso, a manutenção de populações maiores que aquelas possíveis dentro das áreas protegidas.

Para Ishihata (1999), a finalidade principal da zona tampão é conter os efeitos de borda decorrentes da fragmentação do ecossistema. Segundo Bensusan (2001), as Zonas de Amortecimento têm como objetivo minorar as conseqüências negativas do efeito de borda e transformá-las em bordas "suaves". Para a autora, espera-se encontrar nas bordas "suaves" alta densidade e riqueza de espécies de plantas, mamíferos, aves e invertebrados, além de altos níveis de produção de flores e frutos, densidade de polinizadores e dispersores de sementes. 
Os hábitats fragmentados ou ilhas de hábitats diferenciados podem ser produzidos por diversos processos naturais, sendo fundamental diferenciar as áreas isoladas naturalmente dos fragmentos produzidos pela ação antrópica (CONSTANTINO et al., 2003).

Brito (2003); Dias (2001); Primack e Rodrigues (2001) e Soulé (1991) propõem que o monitoramento da biodiversidade nas áreas protegidas incorpore os principais fatores impactantes decorrentes das intervenções humanas, tais como: perda e fragmentação dos hábitats; introdução de espécies e doenças exóticas ou transgênicas; exploração excessiva de espécies de plantas e animais; uso de híbridos e monoculturas na agroindústria e silvicultura; contaminação do solo, água e atmosfera e mudanças climáticas globais.

Além dos impactos previsíveis de alterações do uso do solo, de eventuais indústrias poluentes, de possíveis incêndios, os próprios efeitos das modificações ambientais decorrentes do isolamento são impactos importantes sobre os ecossistemas das áreas protegidas (HAILA, 1999; ISHIHATA, 1999).

Saunders, Hobbs e Margules (1991), em ampla revisão sobre esses impactos, relacionaram como principais os seguintes efeitos de borda: aumento da velocidade do vento, redução da umidade relativa, aumento da incidência de luz, alterações no fluxo de água, aumento da radiação, ocasionando nas bordas temperaturas mais altas durante o dia e mais baixas à noite, tanto na superfície quanto na camada superficial do solo e a maior incidência de geadas.

Vio (2001), ao apontar os vários problemas que determinam a necessidade das Zonas de Amortecimento, destaca: i) “contenção do efeito de borda promovido pela interferência antrópica no sistema natural de Proteção Integral; ii) atenuar os impactos ambientais promovidos pelas práticas rurais antiambientais, principalmente o uso de agrotóxicos e de fogo; iii) a necessidade de ampliar o espaço físico das unidades em função da redução de hábitat (...)”.

Há, atualmente, um consenso global de que unidades de conservação não podem ser 
operadas como ilhas, devendo ser estabelecidas estratégias de manejo em escalas maiores, com a criação de zonas tampão (Morsello, 2001).

\section{A evolução da legislação relativa à zona tampão no Brasil}

O Decreto Federal $n^{\circ}$. 84.017/79, que instituiu o Regulamento dos Parques Nacionais Brasileiros, poderia ter sido o primeiro instrumento jurídico a tratar da zona tampão, mas foi omisso quanto ao assunto em sua proposta de zoneamento, que inclui apenas as terras que compõem a unidade de conservação. Esse Decreto seguiu a proposta de zoneamento feita pela IUCN em sua $11^{\text {a }}$ Assembléia Geral em 1972, que não previa zona tampão (BRITO, 2003).

O conceito de zona tampão surge no Brasil com o Decreto Federal $n^{\circ} .99 .274 / 90$, em seu artigo 27, que se refere a "áreas circundantes das unidades de conservação...", que deverão sofrer restrições de uso. Este Decreto regulamentou a Lei $n^{0}$. 6.902/81 e a Lei $n^{0}$. 6.938/81, que dispõem, respectivamente, sobre a Criação de Estações Ecológicas e Áreas de Proteção Ambiental e sobre a Política Nacional do Meio Ambiente e demais providências.

A redação do Decreto Federal supramencionado estabelece que:

Art. $7^{\mathbf{0}}, \mathbf{X}$ - Compete ao CONAMA:

estabelecer normas gerais relativas às Unidades de Conservação e às atividades que podem ser desenvolvidas em suas áreas circundantes.

Art. 27 - Nas áreas circundantes das Unidades de Conservação, num raio de $10 \mathrm{~km}$ (dez quilômetros), qualquer atividade que possa afetar a biota ficará subordinada às normas editadas pelo CONAMA.

Tanto o art. $7^{\circ}, \mathrm{X}$ quanto o art. 27 utilizam o termo "Unidades de Conservação" de modo abrangente, pois não especificam, em si mesmos, as categorias de UCs nas quais serão aplicadas as normas transcritas. O artigo 27, porém, está inserido no capítulo que trata de Estações 
Ecológicas, dando margem à interpretação de que só se aplicaria a esta categoria de manejo.

A Resolução CONAMA 13/90, em seu caput, estabeleceu normas relacionadas ao licenciamento de obras no entorno das unidades de conservação, objetivando a proteção dos ecossistemas, como segue:

Art. $1^{0}$ - O Órgão responsável por cada Unidade de Conservação, juntamente com os órgãos licenciadores e de meio ambiente, definirá as atividades que possam afetar a biota da Unidade de Conservação.

Art. $\mathbf{2}^{\mathbf{0}}$ - Nas áreas circundantes das Unidades de Conservação, num raio de dez quilômetros, qualquer atividade que possa afetar a biota, deverá ser obrigatoriamente licenciada pelo órgão ambiental competente.

Parágrafo Único - O licenciamento a que se refere o caput deste artigo só será concedido mediante autorização do órgão responsável pela administração da Unidade de Conservação.

A Resolução CONAMA nº. 10/93 vem reforçar a vigência da Resolução CONAMA

13/90, ao estabelecer parâmetros básicos para análise dos estágios de sucessão da Mata Atlântica, ao definir:

Art. $\mathbf{6}^{\mathbf{0}}, \mathbf{I V}$ - Entorno de Unidades de Conservação - área de cobertura vegetal contígua aos limites de Unidade de Conservação, que for proposta em seu respectivo Plano de Manejo, Zoneamento Ecológico/Econômico ou Plano Diretor de acordo com as categorias de manejo. Inexistindo estes instrumentos legais ou deles não constando a área de entorno, o licenciamento se dará sem prejuizo da aplicação do disposto no artigo $2^{\circ}$ da Resolução/CONAMA $n^{\circ}$. $13 / 90$.

Novas normas tratando dessa área destinada a mitigar os impactos sobre as unidades de conservação foram estabelecidas pela Lei $n^{\circ}$. 9.985/00, que instituiu o Sistema Nacional de Unidades de Conservação (SNUC), que define:

Art. $\mathbf{2}^{\mathbf{0}}$, inciso XVI - zoneamento: definição de setores ou zonas em uma unidade de conservação com objetivos de manejo e normas especificos, com o propósito de proporcionar os meios e as condições para que todos os objetivos da unidade possam ser alcançados de forma harmônica e eficaz;

Art.2 ${ }^{\circ}$, inciso XVIII - Zona de Amortecimento: o entorno de uma unidade de conservação, onde as atividades humanas estão sujeitas a normas e restrições especificas, com o propósito de minimizar os impactos negativos sobre a 
unidade.

Art. 25 - As unidades de conservação, exceto Área de Proteção Ambiental e Reserva Particular do Patrimônio Natural, devem possuir uma zona de amortecimento e, quando conveniente, corredores ecológicos.

$\S 1^{\circ} O$ órgão responsável pela administração da unidade estabelecerá normas especificas regulamentando a ocupação e o uso dos recursos da zona de amortecimento e dos corredores ecológicos de uma unidade de conservação.

$\S 2^{\circ}$ Os limites da zona de amortecimento e dos corredores ecológicos e as respectivas normas de que trata o $\S 1^{\circ}$ poderão ser definidas no ato de criação da unidade ou posteriormente.

Art. 27 - As unidades de conservação devem dispor de um Plano de Manejo. $\S 1^{\circ}$ O Plano de Manejo deve abranger a área da unidade de conservação, sua zona de amortecimento e os corredores ecológicos, incluindo medidas com o fim de promover sua integração à vida econômica e social das comunidades vizinhas.

Com base no SNUC, portanto, depreende-se que as dimensões da Zona de Amortecimento de uma unidade de conservação devem ser estabelecidas no ato de sua criação ou quando da elaboração de seu Plano de Manejo.

O SNUC, no entanto, não trata das normas de licenciamento ambiental no interior da Zona de Amortecimento, objeto da Resolução CONAMA 13/90, deixando margem à interpretação de que esta norma deixou de vigorar. Mas, ao estabelecer que "nesta Zona as atividades humanas estarão sujeitas a normas e restrições específicas”, fica implícito que tais restrições carecem de regulamentação. Uma vez que a lei que instituiu o SNUC não estabelece sanções para o descumprimento das normas relativas à Zona de Amortecimento, não há respaldo jurídico para fazer valerem essas normas a não ser aqueles contidos na Resolução 13/90, no artigo 27 do Decreto Federal nº 99.274/90 e na Lei no. 9.985 (Crimes Ambientais).

Posteriormente, o Decreto Federal $n^{\circ} .3 .942 / 01$ revogou o art. $7^{\circ}$ do Decreto Federal $n^{\circ}$. 99.274/90, retirando, do CONAMA, a competência de "estabelecer normas gerais relativas às unidades de conservação e às atividades que podem ser desenvolvidas em suas áreas circundantes". Mas, o art.27 continua em vigor e, portanto, pelo menos para a categoria Estação 
Ecológica, a Resolução CONAMA nº $.13 / 90$ continua em vigência.

Milaré (2007) discorda desse posicionamento. Para o autor, o art.25 da Lei $n^{\circ} .9 .985 / 00$ revogou a Resolução CONAMA 13/90, que, em seu entender, dispunha sobre o mesmo objeto. Esse autor ressalta que: "os limites da zona de amortecimento e as normas específicas regulando os usos nela admitidos serão estabelecidos no ato de criação da unidade ou posteriormente". Portanto, para Milaré (2007), não existe mais motivo para se falar na Zona de Amortecimento de dez quilômetros no entorno da unidade, de acordo com o que dispunha a Resolução CONAMA 13/90, sendo válida a delimitação e as normas que vierem a ser estabelecidas no Plano de Manejo. Neste caso, a regulamentação das atividades no entorno das UCs deixaria de ter respaldo em lei.

A nosso ver, porém, com base nas disposições contidas e ainda vigentes nos dois instrumentos jurídicos (Resolução CONAMA e SNUC) e em normas complementares, toda atividade potencialmente impactante no raio de $10 \mathrm{~km}$ no entorno de uma Estação Ecológica deverá ser objeto de licenciamento e, no processo, deve ser ouvido o órgão gestor da unidade. Esta é, também, a interpretação de Oliva (2003), que considera que a Zona de Amortecimento (SNUC) é um refinamento da Zona de Entorno (CONAMA 13/90) e pode agregar critérios e diretrizes fundamentais para o licenciamento ambiental e também para a proteção e manejo desse território no entorno da unidade.

Vigora, ainda, o Art. $1^{\circ}$ da Resolução CONAMA 13/90, que determina que cabe ao órgão gestor, juntamente com os órgãos licenciadores e de meio ambiente, definir quais são as atividades que podem afetar a biota dos ecossistemas protegidos.

Tais atividades, portanto, para que possam ser evitadas, devem ser claramente indicadas quando da elaboração das normas da Zona de Amortecimento, no Plano de Manejo.

Resta uma lacuna na legislação nos casos em que a Zona de Amortecimento estabelecida 
no Plano de Manejo ultrapassar os 10 km de que trata a Resolução CONAMA 13/90.

A Zona de Entorno $(10 \mathrm{~km})$ é, ainda, protegida pela Lei $\mathrm{n}^{\circ} .9 .605 / 98$ (Lei de Crimes Ambientais), que dispõe sobre as sanções penais e administrativas derivadas de condutas e atividades lesivas ao meio ambiente, que considera crime ambiental:

Art. 40. Causar dano direto ou indireto às Unidades de Conservação e às áreas de que trata o art. 27 do Decreto $n^{\circ}$. 99.274, de 6 de junho de 1990, independentemente de sua localização:

Pena - reclusão, de um a cinco anos.

Assim, uma vez indicadas pelo órgão gestor e apontadas nas normas da Zona de Amortecimento estabelecidas pelo Plano de Manejo, as atividades que venham a ser indicadas como potencialmente impactantes para os ecossistemas das unidades de conservação passarão a ser crime ambiental, se desenvolvidas dentro da área delimitada como Zona de Amortecimento, sem o devido licenciamento.

Esta particularidade da lei, no entanto, não é de conhecimento dos gestores de UCs e não tem sido levada a conhecimento dos proprietários de terras contidas nas zonas tampão de unidades de conservação e não tem sido aplicada pelos órgãos licenciadores, que raramente cumprem o disposto na Resolução CONAMA 13/90, que determina que em todos os pedidos de licenciamento ambiental nessas áreas o órgão gestor deve ser ouvido (VITALLI, 2007). Desta forma, a lei resulta inócua.

\section{A natureza jurídica da zona tampão}

A existência de normas incidindo sobre as propriedades particulares inseridas na zona tampão de Unidades de Conservação invariavelmente desperta questionamentos quanto à sua 
natureza jurídica e suas interfaces com outros dispositivos legais.

A intervenção do Estado na propriedade privada foi estudada por alguns juristas, tais como: Gasparini (2002); Meirelles (1992); Bastos (1994) e Di Pietro (2006). O Estado intervém na propriedade privada com a finalidade de proporcionar qualidade de vida a toda a coletividade e para assegurar a conservação do ecossistema, acabando por impor aos particulares certas limitações ao exercício do direito de propriedade.

De acordo com Meirelles (1992), "os Estados sociais-liberais, ao mesmo tempo em que reconhecem e asseguram a propriedade privada e a livre empresa, condicionam o uso dessa mesma propriedade e o exercício das atividades econômicas ao bem-estar social - CF, art.170"1. Complementa o mesmo autor que, para usufruir e gozar dos bens e riquezas particulares, o Poder Público impõe normas e limites e, quando o interesse público o exige, intervém na propriedade privada e na ordem econômica, por meio de atos de império tendentes a atender as exigências coletivas e a reprimir a conduta anti-social da iniciativa particular.

Essa intervenção, entretanto, não se realiza arbitrariamente, por critérios pessoais das autoridades. É normatizada pela Constituição e regulamentada por leis federais que disciplinam as medidas interventivas e estabelecem o modo e forma de sua execução, sempre condicionada ao atendimento do interesse público e ao respeito dos direitos individuais assegurados pela mesma Constituição (MEIRELLES, 1992).

Alguns dos atos de intervenção Estatal na propriedade privada são: desapropriação, servidão administrativa, requisição administrativa, tombamento e limitação administrativa (BASTOS, 1994).

\footnotetext{
${ }^{1}$ Dispõe o art. 170, caput: A ordem econômica, fundada na valorização do trabalho humano e na livre iniciativa, tem por fim assegurar a todos existência digna, conforme os ditames da justiça social, observados os seguintes princípios.
} 
Dentre as modalidades citadas de intervenção do Estado, destaca-se a limitação administrativa, que é uma das formas pela qual: "o Estado, no uso de sua soberania interna, intervém na propriedade e nas atividades particulares" (MEIRELLES, 1992).

Reitera ainda o autor que "limitação administrativa é toda imposição geral, gratuita, unilateral e de ordem pública, condicionadora do exercício de direitos ou de atividades particulares às exigências do bem-estar social”.

Corrobora a idéia Di Pietro (2006), para quem:

as limitações podem, portanto, ser definidas como medidas de caráter geral, previstas em lei, com fundamento no poder de polícia do Estado, gerando para os proprietários obrigações positivas ou negativas, com o fim de condicionar o exercício do direito de propriedade ao bem-estar social.

Para o presente estudo, a modalidade de intervenção pertinente é a limitação administrativa. A Zona de Amortecimento (SNUC) e a Zona de Entorno (Resolução CONAMA 13/90 - BRASIL, 1990b) podem ser classificadas como uma limitação administrativa, pois ambas condicionam o exercício do direito de propriedade ao cumprimento da função ambiental da propriedade, ou seja, pela obrigatoriedade do proprietário rural zelar pela proteção e conservação ambiental em prol do bem-estar da coletividade.

Orlando (1997) segue a mesma linha de raciocínio ao afirmar que o uso do entorno de cada unidade de conservação deve ser controlado, impondo-se limitações administrativas ao exercício do direito de propriedade ao particular.

\section{A zona tampão mediante outros institutos jurídicos}

A existência da Zona de Amortecimento ou de Entorno e sua efetiva implantação como uma zona de uso restrito às atividades humanas, com finalidade de funcionar como anteparo às 
ações possivelmente impactantes (fogo, erosão, invasão de plantas exóticas e espécies animais, dentre outros) sobre unidades de conservação, desencadeia questionamentos sobre competências e hierarquia no campo jurídico, analisadas a seguir.

Se, por um lado, cabe ao governo federal, legislar sobre a conservação dos recursos naturais sob um ponto de vista amplo, as unidades de conservação situam-se nos municípios e esta circunstância faz com que sua existência exija tratamento jurídico local, especialmente no tocante ao ordenamento territorial.

Para que as leis, quando forem aplicadas, não ensejem dúvidas e não acarretem conflitos, a Constituição Federal tratou de definir a competência de cada ente federativo para legislar sobre determinado assunto. A Constituição Federal previu dois tipos de competência para legislar, com referência a cada um dos membros da Federação: a União tem competência privativa e concorrente; os Estados e o Distrito Federal têm competência concorrente e suplementar e os Municípios têm competência para legislar sobre assuntos de interesse local e para suplementar a legislação federal e estadual (MACHADO, 2007).

Barroso (1992) constata que:

a tutela dos interesses ambientais enfatiza certas peculiaridades do federalismo brasileiro, por envolver o exercício de competências político-administrativas comuns e competências legislativas concorrentes entre a União, os Estados e os Municípios. Os balizamentos constitucionais da esfera de atuação de cada entidade nem sempre são objetivamente aferíveis, e caberá ao Judiciário dirimir os conflitos, que se afiguram inevitáveis.

$\mathrm{Na}$ questão ambiental compete à União, aos Estados e ao Distrito Federal legislarem concorrentemente sobre: florestas, caça, pesca, fauna, conservação da natureza, defesa do solo e dos recursos naturais, proteção do meio ambiente e controle da poluição (Constituição Federal, 
Art. $24, \mathrm{VI})^{2}$.

Cabe ressaltar, também, que os municípios possuem competência suplementar para promoverem o ordenamento territorial, por meio de planejamento e controle do uso do solo, parcelamento e a ocupação do solo urbano (art. 30, VIII) ${ }^{3}$.

Em tese, não há necessariamente uma separação material entre economia e ecologia. Ocorre que a base do desenvolvimento das relações produtivas está na natureza e a natureza só pode ser compreendida como integrante das relações humanas e, por conseqüência, também das relações econômicas (DERANI, 1997). Complementa a autora que esta união indissolúvel tem de se fazer sentir no ordenamento jurídico. Interesses econômicos e conservação de recursos naturais são tidos como valores constitucionais relevantes, sendo que o primeiro é disciplinado pelo art. $3^{\circ}$, inciso II (BRASIL, 1988 ${ }^{4}$ ), como a “defesa do meio ambiente” é disciplinada pelo art. 170, inciso $\mathrm{VI}^{5}$ e art.225 (BRASIL, 1988).

Tal conflito de interesses foi descrito na ementa publicada pelo Supremo Tribunal Federal (STF), tratando da supressão de vegetação natural em Áreas de Preservação Permanente, nos casos em que a ação fosse de utilidade pública. Esta ementa trata de uma Ação Direta de Inconstitucionalidade questionando o artigo $1^{\circ}$ da Medida Provisória $n^{\circ} .2 .166-67$, de 24 de agosto de 2001 (BRASIL, 2001b), na parte em que alterou o artigo $4^{\circ}$, caput e $\S \S 1^{\circ}$ a $7^{\circ}$, da Lei

\footnotetext{
${ }^{2}$ Art. 24. Compete à União, aos Estados e ao Distrito Federal legislar concorrentemente sobre: VI - florestas, caça, pesca, fauna, conservação da natureza, defesa do solo e dos recursos naturais, proteção do meio ambiente e controle da poluição;

${ }^{3}$ Art. 30. Compete aos Municípios: VIII - promover no que couber, adequado ordenamento territorial, mediante planejamento e controle do uso, do parcelamento e da ocupação do solo urbano.

${ }^{4}$ Art. $3^{\circ}$. Constituem objetivos fundamentais da República Federativa do Brasil: II - garantir o desenvolvimento nacional.

5 Art. 170, VI - defesa do meio ambiente, inclusive mediante tratamento diferenciado conforme o impacto ambiental dos produtos e serviços e de seus processos de elaboração e prestação.
} 
nº. 4.771, de 15 de setembro de 1965 (Código Florestal - BRASIL, 1965) ${ }^{6}$.

A fundamentação utilizada pelo STF no julgamento é de que a atividade econômica não pode ser exercida em desarmonia com os princípios destinados a tornar efetiva a proteção ao meio ambiente. A conservação da natureza e o desenvolvimento econômico só serão realmente efetivos se o conceito de desenvolvimento sustentável for realmente empregado no exercício da atividade econômica. Apesar de apresentar argumentos protecionistas, o STF proferiu decisão desfavorável à questão ambiental, configurando-se assim, um exemplo concreto de conflito entre interesses econômicos e interesses conservacionistas, em que se priorizaram os primeiros, decisão que pode repetir-se facilmente na zona tampão de unidades de conservação. $\mathrm{O}$ desafio está em conciliar as atividades econômicas em consonância com as premissas estipuladas pelo desenvolvimento sustentável.

O conceito de desenvolvimento sustentável fortaleceu-se por meio da publicação do Brundtland Report em 1987 (GONÇALVES; DUARTE, 2006), este relatório auxiliou na propagação da definição de desenvolvimento sustentável, ao ressaltar que: "é aquele que atende às necessidades do presente, sem comprometer o atendimento às necessidades das gerações futuras". Tal conceito foi incorporado em nosso ordenamento pela Constituição (art.225, caputBRASIL, 1988) ${ }^{7}$.

Unidades de conservação, muitas vezes, avizinham-se de núcleos urbanos e sofrem pressões constantes oriundas da própria urbe e, também, estão permanentemente sob a ameaça de que a cidade avance rumo aos limites da área protegida.

\footnotetext{
${ }^{6}$ Art. $4^{\text {o }}$, caput, A supressão de vegetação em área de preservação permanente somente poderá ser autorizada em caso de utilidade pública ou de interesse social, devidamente caracterizados e motivados em procedimento administrativo próprio, quando inexistir alternativa técnica e locacional ao empreendimento proposto

${ }^{7} \mathrm{O}$ art. 225, caput, da Constituição Federal estabelece: Todos têm direito ao meio ambiente ecologicamente equilibrado, bem de uso comum do povo e essencial à sadia qualidade de vida, impondo-se ao Poder Público e à coletividade o dever de defendê-lo e preservá-lo para as presentes e futuras gerações.
} 
Metade da população mundial vive em cidades, com expectativa de aumento para $60 \%$ em 2030 (ACKERMAN, 2006), levando à inevitável expansão urbana. Em decorrência disso, as populações pressionam as áreas protegidas com o intuito de a ocuparem para fins de moradia ou para extraírem dessas áreas recursos para sua subsistência.

A colisão de interesses referente à expansão urbana manifesta-se pela medição de forças de dois documentos técnicos de ordenamento do uso do solo pertencentes a diferentes níveis hierárquicos: O Plano Diretor do município e o Plano de manejo da unidade de conservação. O Plano Diretor Municipal (Constituição Federal, art.182 - BRASIL, 1988 ${ }^{8}$ ) trata do planejamento territorial municipal com o propósito de proporcionar aos munícipes o bem-estar social (qualidade de vida) e alcançar a sustentabilidade no ambiente urbano construído como preconiza o Estatuto da Cidade (Lei no.10.257, de 10 de julho de 2001 - BRASIL, 2001a9 $)$.

Por outro lado, conforme conceitua o SNUC (artigos. $2^{\circ}$, inc.XVII e $27, \S 1^{\circ}, \S 2^{\circ}, \S 3^{\circ}-$ PINTO; WINDT; SIQUEIRA, 2001), o Plano de Manejo é o documento técnico mediante o qual, com fundamento nos objetivos gerais de uma unidade de conservação, se estabelece o seu zoneamento e as normas que devem presidir o uso e o manejo dos recursos naturais, inclusive a implantação das estruturas físicas e necessárias à gestão da unidade.

Como garantir o direito ao meio ambiente ecologicamente equilibrado (Constituição Federal, art. 225 - BRASIL, 1988), assegurando, com isso, a integridade da unidade de conservação a salvo dos interesses especulativos imobiliários? Este questionamento será

\footnotetext{
${ }^{8}$ Diz o art. 182, caput, da Constituição Federal: A política de desenvolvimento urbano, executada pelo Poder Público municipal, conforme diretrizes gerais fixadas em lei, tem por objetivo ordenar o pleno desenvolvimento das funções sociais da cidade e garantir o bem-estar de seus habitantes.

${ }^{9}$ Estabelece a Lei $n^{\circ}$. 10.257/01 em seu art. $1^{\circ}$ e Parágrafo único que: Na execução da política urbana, de que tratam os arts. 182 e 183 da Constituição Federal, será aplicado o previsto nesta Lei. Parágrafo único. Para todos os efeitos esta Lei, denominada Estatuto da Cidade, estabelece normas de ordem pública e interesse social que regulam o uso da propriedade urbana em prol do bem coletivo, da segurança e do bem-estar dos cidadãos, bem como do equilíbrio ambiental.
} 
elucidado no decorrer da presente pesquisa.

O reconhecimento jurídico da existência da Zona de Amortecimento, em que os proprietários se vêem mediante a possibilidade de ter limitada sua liberdade de decidir sobre o manejo da propriedade para o bem do ecossistema protegido pela unidade de conservação, vislumbra-se para essa situação a possibilidade de um conflito entre o direito coletivo ao meio ambiente ecologicamente equilibrado e o direito (individual) de propriedade.

A questão que se coloca, no caso, é se cabe aos gestores da unidade de conservação impor limitações ao exercício do direito de propriedade, quando as propriedades encontram-se situadas na Zona de Amortecimento.

Machado (2007), ao discorrer sobre direito de propriedade, zonas de amortecimento e corredores ecológicos, afirmou que o Poder Público, por meio do Plano de Manejo, pode restringir o uso da propriedade pública. Porém, ressaltou que as zonas de amortecimento e os corredores ecológicos, normalmente, não são de domínio público. Em sendo de domínio privado, são protegidos pela Constituição Federal de 1988, que assegura o direito de propriedade (artigo. $5^{\circ}$, inciso XXII - BRASIL, $1988^{10}$ ), mas afirma que a propriedade terá de atender, obrigatoriamente, à sua função social (artigo. $5^{\circ}$, inciso XXIII - BRASIL, 1988 ${ }^{16}$ ).

Na opinião de Santos (2003), o direito de propriedade pode ser limitado nas zonas de amortecimento e nos corredores ecológicos, desde que "não inviabilize a propriedade, sob pena de acarretar apossamento administrativo, com o conseqüente dever de indenizar o proprietário, por parte do Poder Público".

Compartilha do mesmo pensamento Milaré (2007), que assevera que a zona de

\footnotetext{
${ }^{10}$ Determina a Constituição Federal, no art. $5^{\circ}$ que: Todos são iguais perante a lei, sem distinção de qualquer natureza, garantindo-se aos brasileiros e aos estrangeiros residentes no País a inviolabilidade do direito à vida, à liberdade, à igualdade, à segurança e à propriedade, nos termos seguintes: XXII - é garantido o direito de propriedade. Art. $5^{\circ}$, XXIII - a propriedade atenderá a sua função social.
} 
amortecimento não é elemento da unidade de conservação, mas por força da nova Lei, fica sujeita a uma espécie de zoneamento obrigatório, pelo qual certas atividades econômicas são permitidas e regradas. Ressalta o autor, que se tratando de propriedade privada, não cabe, como regra geral, indenização, pois o imóvel apenas sofrerá certas restrições e uma regulamentação da atividade, e, obviamente, de modo não tão restritivo como ocorre dentro das unidades de conservação. Todavia, as limitações não podem inviabilizar o direito de propriedade e seu exercício, sob pena de ocasionar apossamento administrativo com o conseqüente dever de indenizar por parte do Poder Público.

Ao limitar-se o pleno exercício do direito de propriedade pelas normas estabelecidas no Plano de Manejo, os gestores da unidade de conservação estarão exercendo um poder que não possuem, ou seja, o poder de polícia. Segundo Di Pietro (2006, p.128):

Poder de polícia é a atividade do Estado consistente em limitar o exercício dos direitos individuais em benefício do interesse público. Esse interesse público diz respeito aos mais diversificados setores da sociedade, tais como segurança, moral, saúde, meio ambiente, defesa do consumidor, patrimônio cultural e propriedade.

O conceito legal de poder de polícia origina-se do artigo. 78 do Código Tributário Nacional $(\mathrm{CTN})^{11}$.

Para Figueiredo e Leuzinger (2001), a criação de espaços territoriais especialmente protegidos (art.225, III, Constituição Federal - BRASIL, $1988^{12}$ ), quando em áreas particulares, acarreta restrições ao exercício do direito de propriedade, que nem sempre são indenizáveis,

\footnotetext{
11 Art. 78, CTN: Considera-se poder de polícia a atividade da administração pública que limitando ou disciplinando direito, interesse ou liberdade, regula a prática de ato ou abstenção de fato, em razão de interesse público concernente à segurança, à higiene, à ordem, aos costumes, à disciplina da produção e do mercado, ao exercício de atividades econômicas dependentes de concessão ou autorização do Poder Público, à tranqüilidade pública ou ao respeito à propriedade e aos direitos individuais ou coletivos.

12 Art. 225, III - definir em todas as unidades da federação, espaços territoriais e seus componentes a serem especialmente protegidos, sendo a alteração e a supressão permitidas somente através de lei, vedada qualquer utilização que comprometa a integridade dos atributos que justifiquem sua proteção.
} 
tendo em vista decorrerem, tais limitações, em grande parte, do cumprimento da função social da propriedade, em que se inclui a função ambiental.

Nem sempre as restrições ao direito de propriedade são passíveis de indenização. Porém, a lei que trata sobre a Política Agrícola - Lei no . 8.171/91 (BRASIL, 1991) prevê, no art.103, que o Poder Público concederá incentivos especiais ao proprietário que preservar e conservar a cobertura florestal de sua propriedade ${ }^{13}$.

O SNUC dispõe sobre 12 tipos de unidades de conservação. No entanto, somente dois tipos não estão obrigados a ter Zonas de Amortecimento (art.25 da Lei 9.985/00 - PINTO; WINDT; SIQUEIRA, 2001): Área de Proteção Ambiental (APA) e Reserva Particular do Patrimônio Nacional (RPPN).

Portanto, a Estação Ecológica, a Reserva Biológica, o Parque Nacional, o Monumento Natural, o Refúgio de Vida Silvestre, a Área de Relevante Interesse Ecológico, a Floresta Nacional, a Reserva Extrativista, a Reserva da Fauna e a Reserva de Desenvolvimento Sustentável não podem realizar totalmente seus objetivos se não houver uma separação gradativa entre o meio ambiente antropicamente trabalhado e o meio ambiente natural (MACHADO, 2007).

Complementa o autor que há atividades e obras que não têm justificativa de estar na vizinhança de uma unidade de conservação, tais como: aeroportos, estações rodoviárias ou ferroviárias, distritos industriais, aplicação de agrotóxicos por meio de aviões ou helicópteros,

\footnotetext{
13 Diz a Lei nº. 8.171/91 em seu art. 103. O Poder Público, através dos órgãos competentes, concederá incentivos especiais ao proprietário rural que: I - preservar e conservar a cobertura florestal nativa existente na propriedade; II recuperar com espécies nativas ou ecologicamente adaptadas as áreas já devastadas de sua propriedade; III - sofrer limitação ou restrição no uso de recursos naturais existentes na sua propriedade, para fins de proteção dos ecossistemas, mediante ato do órgão competente, federal ou estadual.
} 
experimentos agrícolas ou pecuários com a introdução de organismos geneticamente modificados e áreas de exercícios militares.

Pondera Machado (2007) que os usos agrícolas ou pecuários já anteriormente existentes na área de entorno da unidade de conservação, que se tornará Zona de Amortecimento, não podem ser impedidos, sob pena de a medida constituir uma desapropriação indireta.

As normas de gestão da Zona de Amortecimento que venham a ser estabelecidas no Plano de Manejo devem buscar "a integração à vida econômica e social das comunidades vizinhas" $\left(\operatorname{art} .27, \S 1^{\circ}\right.$, do SNUC - PINTO; WINDT; SIQUEIRA, 2001 ${ }^{14}$ ). Quanto ao direito de propriedade, diversos autores têm estudado o tema, tais como: Derani, 2002; Figueiredo, 2004; Machado, 2007.

Destaca-se a acepção jurídica sobre o assunto, a apontada por Derani (2002, p.58), para quem:

Propriedade traduz uma relação sobre a qual recai uma proteção jurídica. Não é a propriedade um direito. Direito é a sua proteção. Assim, direito de propriedade é o direito à proteção da relação de um sujeito sobre um objeto. Somente aquela relação que preenche requisitos determinados pelo direito é passível de ser protegida.

O Novo Código Civil Brasileiro, (BRASIL, 2002a) manteve, no artigo $1.228^{15}$ o conceito, além de inserir a preocupação ambiental ao propor, no $\S 1^{\circ}$, que o exercício do direito de propriedade deve estar condicionado à preservação da flora, da fauna, das belezas naturais, do equilíbrio ecológico, assim como deve ser evitada a poluição do ar e das águas.

\footnotetext{
14 Art. 27. As unidades de conservação devem dispor de um Plano de Manejo. $\S 1^{\circ}$ O Plano de Manejo deve abranger a área da unidade de conservação, sua zona de amortecimento e os corredores ecológicos, incluindo medidas com o fim de promover sua integração à vida econômica e social das comunidades vizinhas.

${ }^{15}$ Art. 1228 - O proprietário tem a faculdade de usar, gozar e dispor da coisa e o direito de reavê-la do poder de quem quer que injustamente a possua ou detenha. $\S 1^{\circ}$ - O direito de propriedade deve ser exercido em consonância com as suas finalidades econômicas e sociais e de modo que sejam preservados, de conformidade com o estabelecido em lei especial, a flora, a fauna, as belezas naturais, o equilíbrio ecológico e o patrimônio histórico e artístico, bem como evitada a poluição do ar e das águas.
} 
A natureza jurídica da função social da propriedade é preceito de ordem pública, não dependendo de mero ato de vontade das partes para ser anulado (NERY JUNIOR; NERY, 2002). Portanto, o parágrafo transcrito determina claramente ao proprietário o exercício de seu direito, em consonância com o cumprimento da função social e ambiental da propriedade.

Em síntese, Figueiredo (2004) discorre dialeticamente sobre a conectividade envolvendo o Direito Ambiental e o direito de propriedade, este último regulamentado também pelo Direito Civil, pelo Administrativo e pelo Econômico. Portanto, as demais áreas jurídicas formam o sustentáculo legal ao princípio relativo à função social da propriedade em sua esfera ambiental.

\section{A zona tampão: da teoria à prática}

Com base na análise de todo o arcabouço jurídico sobre o assunto e na realidade da gestão, foram relacionados (Quadro 1) os principais temas que dizem respeito à efetiva implantação da Zona de Amortecimento de UCs, com aos respectivas responsabilidades de gestores e proprietários, diferenciando estes caso suas terras sejam ou não incluídas na ZA. Desta forma, considera-se que a existência desta zona possa trazer, efetivamente, benefícios à conservação, com ônus mínimo e benefícios eventuais aos proprietários vizinhos das áreas protegidas. 


\begin{tabular}{|c|c|c|c|c|c|c|}
\hline & 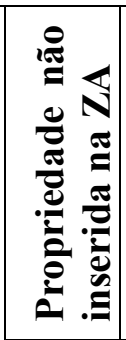 & 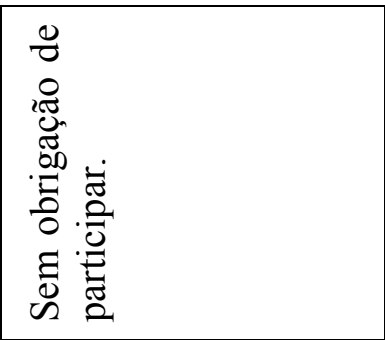 & 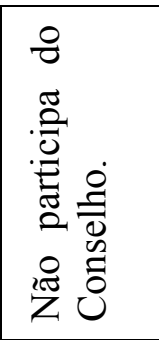 & 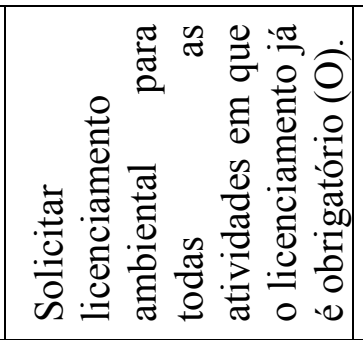 & 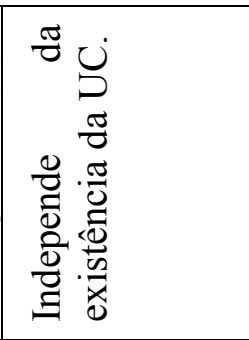 & 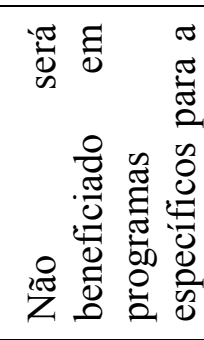 \\
\hline & 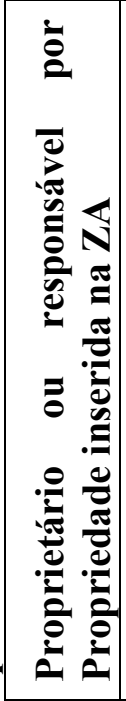 & 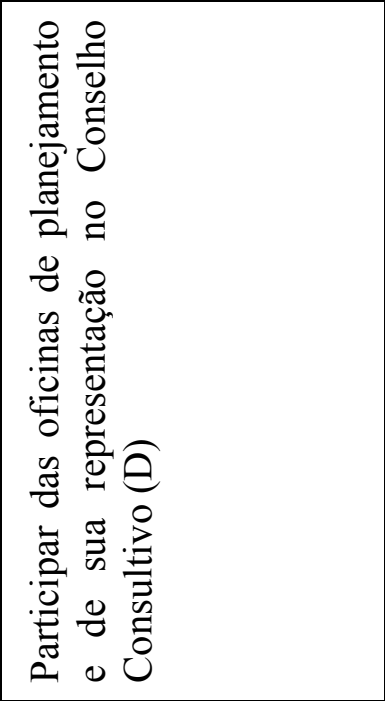 & 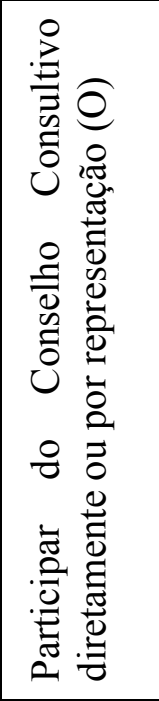 & 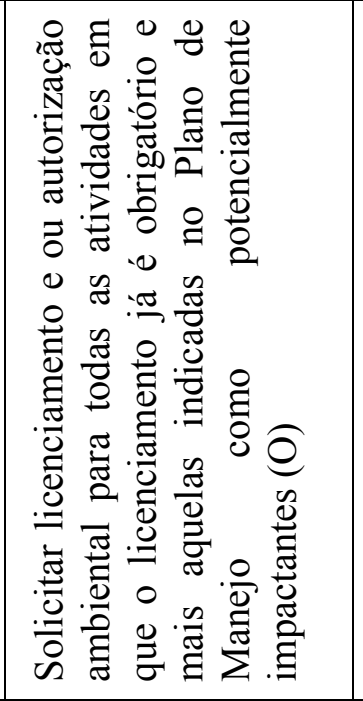 & & 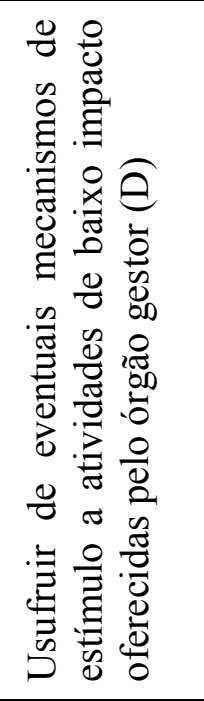 \\
\hline$\approx$ & 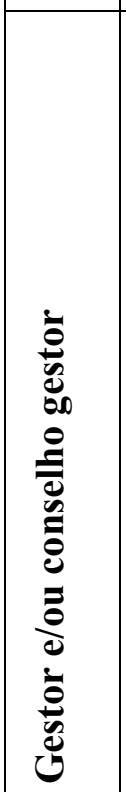 & 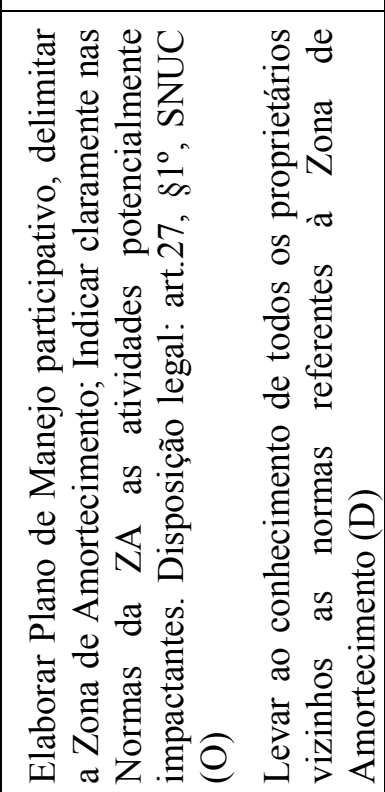 & 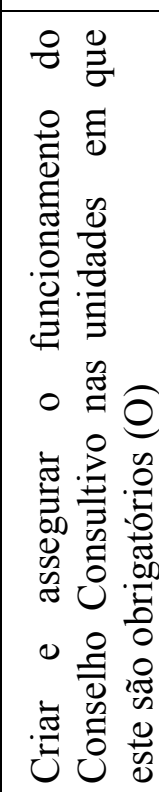 & 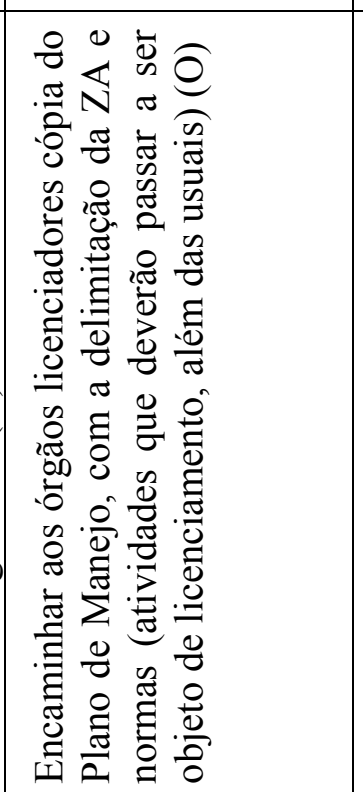 & 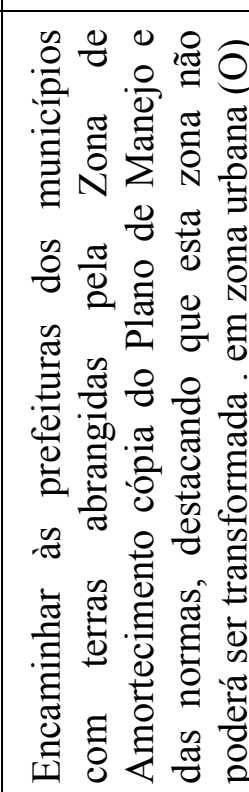 & 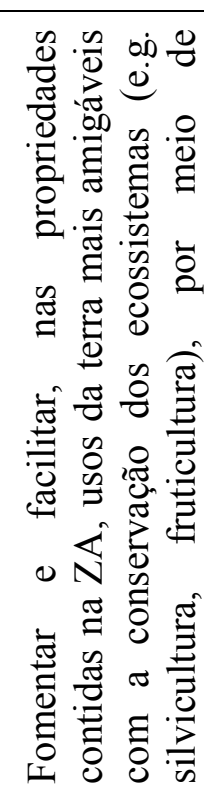 \\
\hline & 餝 & 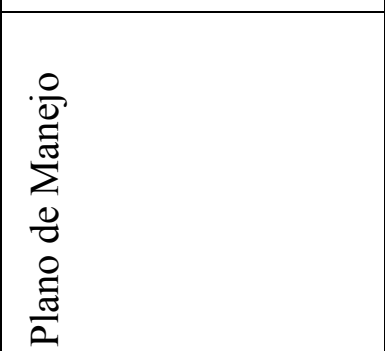 & 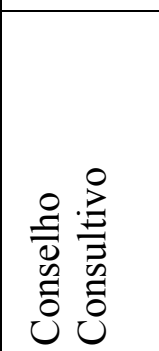 & 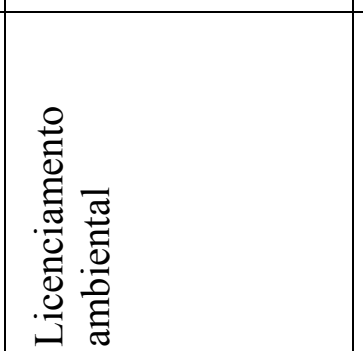 & 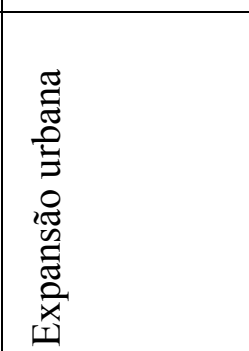 & 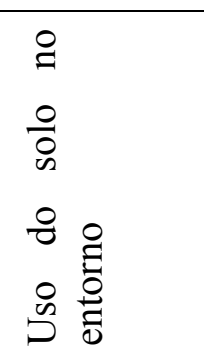 \\
\hline
\end{tabular}




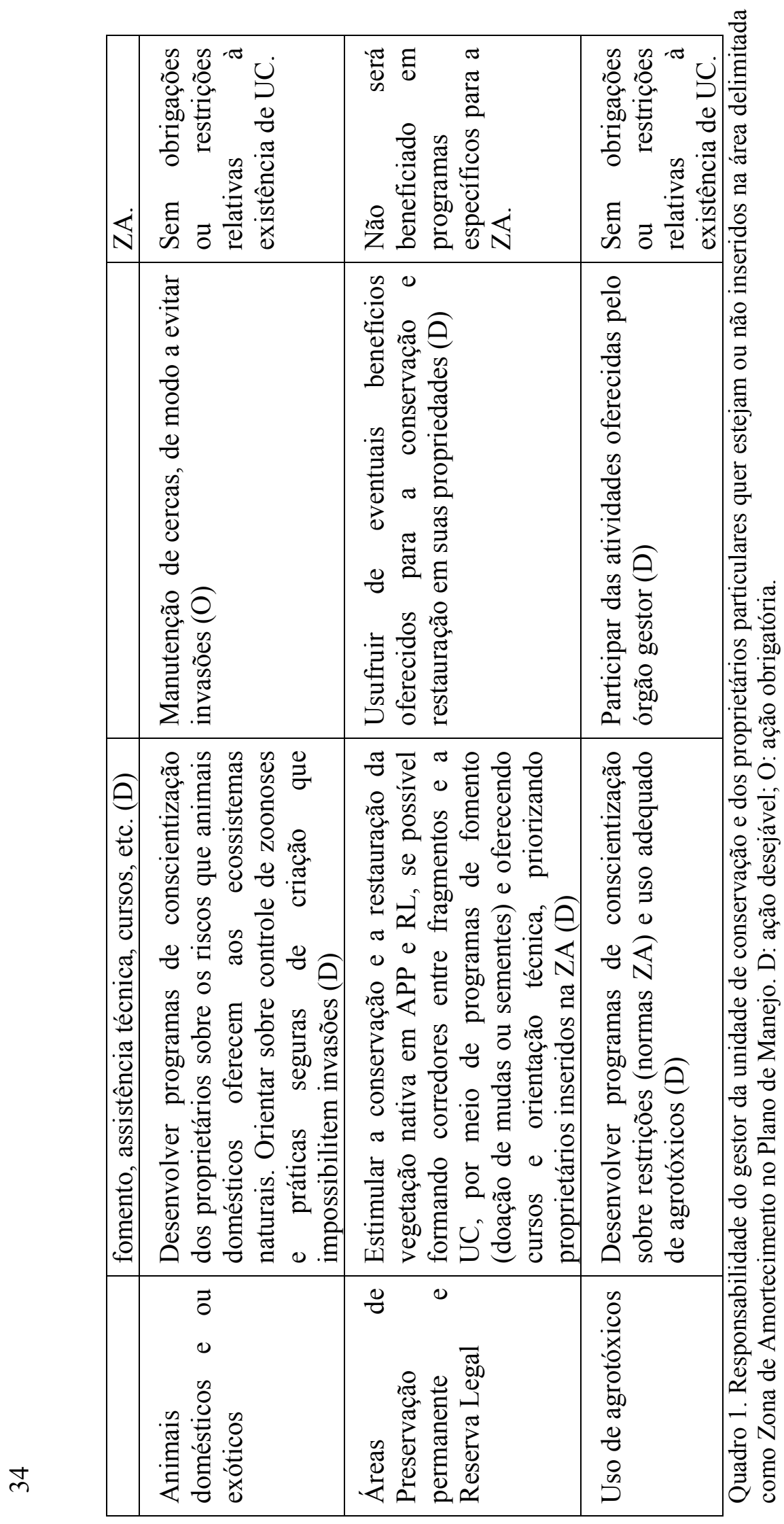


Verifica-se que cabe ao gestor, em um primeiro momento, estabelecer normas claras sobre atividades que não devem ser desenvolvidas na Zona de Amortecimento, de preferência durante as oficinas de elaboração do Plano de Manejo. Em um segundo momento, cabe ao gestor dar conhecimento aos órgãos licenciadores, fiscalizadores e da Administração Municipal, sobre a delimitação e as normas contidas no Plano de Manejo referentes à zona de Amortecimento. Em um terceiro momento, cabe ao gestor criar e assegurar o funcionamento do Conselho Consultivo, que será de grande valia no cumprimento ao disposto no Plano de Manejo.

Por último, e indefinidamente, caberá ao órgão gestor desenvolver atividades voltadas à conscientização, à assistência técnica e ao fomento, voltados às propriedades inseridas na ZA, para que venham a adequar-se à legislação ambiental, converter o uso da terra para alternativas mais amigáveis à conservação e utilizar práticas agropecuárias ambientalmente corretas.

Quanto aos proprietários inseridos na Zona de Amortecimento, caberá inteirar-se e cumprir as normas, participar das atividades do Conselho Consultivo diretamente ou por representação e usufruir de eventuais benefícios oferecidos pelo órgão gestor para estimular o uso ambientalmente correto das terras da vizinhança.

Castanho Filho e Schwenck Jr. (2005) discutem os problemas gerados pelas diferentes interpretações da lei, quanto às atividades que podem ser desenvolvidas ao redor de UCs. Esses autores, ainda que não se aprofundem nos aspectos jurídicos, direcionaram sua argumentação para a conveniência de que a silvicultura fosse incentivada na Zona de Amortecimento, por seus efeitos ambientais benéficos, sem que percam seu caráter produtivo e econômico.

Já Orlando (1997), ao tratar da zona tampão (Zona de Amortecimento e Zona de Entorno), considera que a sua exploração deve, o quanto possível, fazer uso das práticas 
tradicionais, estilos de vida localmente adaptados e manejo sustentável dos recursos naturais. A autora ressalta que é necessário um regulamento específico (além da norma geral) para cada unidade e sua Zona de Entorno, com descrição pormenorizada dos tipos de hábitat, em conjunto com a designação dos riscos que possam gerar problemas para os ecossistemas e as medidas de conservação cabíveis.

Complementa a autora que, conforme estabelecido na lei, caberá ao órgão gestor, juntamente com os órgãos licenciadores e do meio ambiente, definir as atividades potencialmente impactantes, que precisarão de licenciamento. Na opinião da mesma autora, essas atividades consideradas nocivas não deveriam de modo algum ser licenciadas.

Com base na análise do aparato jurídico vigente, considera-se que a Zona de Amortecimento (SNUC) e a Zona de Entorno (Resolução CONAMA 13/90) podem ser classificadas como uma limitação administrativa, pois ambas impõem restrições ao exercício do direito de propriedade, com vistas à proteção dos recursos naturais.

Todavia, a instituição de uma área com restrições de uso ao redor das unidades de conservação no Brasil, ainda que bem intencionada, não se reveste da clareza e objetividade esperadas das leis.

Na prática, cabe aos gestores das unidades de conservação, juntamente com os órgãos licenciadores, indicar quais atividades devem ser submetidas a licenciamento ambiental para que possam ser instaladas na Zona de Amortecimento da Unidade de Conservação. Entende-se que esta indicação deve ser feita no Plano de Manejo, mas o SNUC, que trata do assunto, é omisso quanto à necessidade de licenciamento ambiental na Zona de Amortecimento. Ademais, a Zona de Amortecimento determinada no Plano de Manejo não coincide com a Zona de Entorno estabelecida na Resolução CONAMA 13/90.

Na falta de clareza desses institutos jurídicos, o Plano Diretor surge como um instrumento 
eficiente e de extrema importância, dentro do ordenamento territorial dos municípios, ao atribuir às áreas ao redor das unidades de conservação o status de zonas especiais, voltadas a mitigar os impactos sobre os recursos naturais das unidades de conservação.

Desse modo, a efetiva proteção das unidades de conservação por meio da limitação ou restrição do uso das propriedades situadas ao seu redor depende, essencialmente, do entendimento entre o órgão gestor, os órgãos licenciadores e a administração municipal. E para que as normas estabelecidas não gerem conflitos, os proprietários da vizinhança devem ser envolvidos em todo o processo, de modo que tomem conhecimento das leis e compreendam as restrições de uso que lhes venham a ser impostas.

\section{OBJETIVOS DA PESQUISA}

Apesar da existência de normas jurídicas consolidadas, há controvérsias sobre a interpretação da legislação concernente às Zonas de Amortecimento e Entorno de Unidades de Conservação, que, na prática, dificultam a tomada de decisões por todos os atores sociais envolvidos na prática conservacionista, desde o proprietário das terras inseridas na zona tampão, passando pelo gestor da unidade, órgãos fiscalizadores, Poder Executivo e culminando com divergências na esfera jurídica.

Essas controvérsias motivaram o presente estudo, cujo objetivo geral foi analisá-las em busca de posicionamentos claros que permitam aos tomadores de decisão agir com segurança jurídica em questões relacionadas com a zona tampão de unidades de conservação. A pesquisa como um todo se baseia em um estudo de caso, realizado na Estação Ecológica de Assis (EEcA), unidade de conservação de Proteção Integral dos recursos naturais, administrada pelo Instituto Florestal do Estado de São Paulo. 
A pesquisa foi desenvolvida em duas etapas, tratando de um estudo de caso - a Estação Ecológica de Assis, unidade de conservação administrada pelo Instituto Florestal, órgão este subordinado a Secretaria do Meio Ambiente do Estado de São Paulo, enquadrada na categoria de manejo de Proteção Integral dos recursos naturais.

No capítulo 1, tratou-se das atividades impactantes já existentes ao redor da unidade de conservação. Efetuou-se o diagnóstico e hierarquização das ameaças aos recursos naturais da unidade de conservação e ao desenvolvimento sustentável, oriundas da zona tampão, analisandose os instrumentos jurídicos relacionados com a solução do problema em cada caso.

No capítulo 2, analisou-se a viabilidade de evitar a instalação de novas atividades impactantes dentro dos limites da Zona de Entorno da unidade, com base na aplicação da Resolução CONAMA 13/90 (BRASIL, 1990b), que trata do licenciamento ambiental nessas áreas. 


\section{CAPÍTULO 1 DIAGNÓSTICO DAS ATIVIDADES IMPACTANTES EXISTENTES NA ZONA DE ENTORNO DA ESTAÇÃO ECOLÓGICA DE ASSIS (SP) E ASPECTOS JURÍDICOS CORRELATOS}

\subsection{INTRODUÇÃO}

A preocupação com as ameaças aos recursos naturais da Estação Ecológica de Assis, em decorrência do uso das terras nas áreas que a circundam, motivou a iniciativa dos gestores da unidade em elaborar o Plano de Desenvolvimento Sustentável para o Entorno da Estação Ecológica (MAX et al., 2004a).

O referido Plano baseou-se no diagnóstico das ameaças provenientes do uso da terra ao redor da unidade, sob diversos aspectos. Os autores do estudo mencionado verificaram, por exemplo, a situação dos fragmentos naturais remanescentes e os riscos a que eles estavam expostos e constataram que: $42 \%$ destes encontram-se ameaçados pelo efeito de borda, $25 \%$ devido a falhas na prevenção de incêndios florestais, $11 \%$ pela invasão pelo gado e $11 \%$ pela contaminação por produtos agroquímicos.

Outros dados relevantes constatados sobre os fragmentos relacionam-se a não averbação de reserva legal em grande parte deles (67\%), além do que em $41 \%$ dos casos não são feitas práticas de conservação de solo nas áreas de agricultura ao seu redor, oferecendo risco de erosão e entrada de agrotóxicos nas áreas naturais.

Os autores do documento observaram ainda que $66 \%$ dos fragmentos estão situados nos pontos mais altos das propriedades, permanecendo separados das Áreas de Preservação Permanente da zona ripária (matas ciliares). Analisando os dados referentes ao sistema de produção, na zona tampão da Estação Ecológica de Assis, verificaram ainda que a pecuária e a 
agricultura ocupam 35\% da área e tais atividades são realizadas com baixo nível tecnológico, especialmente sem práticas de conservação do solo e sem recorrer aos avanços da genética e da mecanização agrícola.

Foram identificados, quando da elaboração daquele Plano, que existem problemas de natureza distinta, alguns pontuais e outros envolvendo praticamente toda a zona tampão da unidade de conservação, para os quais foram pensadas soluções técnicas, tais como: terraceamento, utilização de variedades melhoradas e recuperação de matas ciliares. Os autores daquele estudo, porém, não analisaram tais problemas do ponto de vista do nível de ameaça que oferecem aos ecossistemas da Estação Ecológica de Assis e nem, tampouco, restrições de natureza jurídica que possam limitar ou facilitar a ação dos gestores na busca de soluções possíveis visando à cessação dos impactos provenientes das atividades econômicas no entorno da unidade de conservação.

O presente capítulo teve como objetivos específicos: 1) elaborar o diagnóstico das ameaças que possam oferecer riscos à conservação dos ecossistemas naturais e ao desenvolvimento sustentável da região, a partir dos diferentes usos da terra na zona tampão (Zona de Entorno e Zona de Amortecimento) da Estação Ecológica de Assis, SP, e 2) efetuar a análise dessas ameaças e possíveis soluções, inclusive sob o ponto de vista jurídico.

\subsection{MATERIAL E MÉTODOS}

\subsubsection{Local de estudo}

A Estação Ecológica de Assis foi criada pelo Decreto Estadual nº 35.697, de 21 de setembro 1992 (SÃO PAULO, 1992), com área de 1.312,38 ha, a partir do desmembramento da área da então denominada Estação Experimental de Assis. Em 2002, a área foi ampliada pelo 
Decreto Estadual $n^{\circ}$. 47.097, de 18 de setembro de 2002 (SÃO PAULO, 2002), com a incorporação de antigos talhões de Eucalyptus e Pinus, passando a ocupar 1.760,64ha.

A Estação Ecológica de Assis situa-se entre as coordenadas geográficas $22^{\circ} 36^{\prime} 65^{\prime \prime}$ a $22^{\circ} 36^{\prime} 68^{\prime}$ 'S e $50^{\circ} 23^{\prime} 00^{\prime \prime}$ a $50^{\circ} 22^{\prime} 29^{\prime \prime} \mathrm{W}$, abrigando vegetação natural de cerrado lato sensu, predominando a fisionomia cerradão, e áreas menores de cerrado denso, cerrado típico, campo úmido, mata ciliar e mata de brejo (MAX et al., 2004b).

O objetivo principal pelo qual esta unidade de conservação foi criada era para a preservação do ecossistema de cerrado, com a sua biodiversidade e processos ecológicos. A ampliação agregou um novo objetivo - a proteção do manancial, uma vez que a área incorporada contém a principal nascente da Água do Cervo, que abastece a população urbana da cidade de Assis.

O primeiro Plano de Manejo da Estação Ecológica de Assis, elaborado em 1995, foi analisado e aprovado pelo Conselho Técnico do Instituto Florestal (DURIGAN et al., 1995). Trata-se de um documento interno, que não foi publicado. Naquela ocasião, o Plano de Manejo não era obrigatório e não existiam regras claras para sua elaboração. A equipe que elaborou aquele Plano seguiu o método recomendado por Pádua e Porto (1979), que segue o sistema proposto pela FAO (MOSELEY; THELEN; MILLER, 1976). Não era, então, prevista a delimitação da Zona de Amortecimento.

O Plano de Manejo da Estação Ecológica de Assis está em processo de revisão e atualização, estando em discussão, no momento, os limites da Zona de Amortecimento, que incluirá toda a área da Floresta Estadual de Assis e sua Zona de Amortecimento, e expandir-se-á além dela, até os divisores de águas das microbacias hidrográficas do entorno da unidade (Fig.1 do anexo A). 


\subsubsection{Diagnóstico das ameaças}

Os problemas ambientais e potenciais ameaças aos recursos naturais da Estação Ecológica de Assis foram previamente identificados pelo Plano de Desenvolvimento Sustentável para o entorno desta unidade de conservação (MAX et al., 2004a) e encontram-se mapeados e dispostos na Figura 2 do anexo A.

Cabe ressaltar que o conceito de ameaça utilizado neste estudo empresta-se da Convenção sobre Diversidade Biológica. A Convenção sobre Diversidade Biológica não exige que a ameaça seja "séria ou irreversível”, mas que a ameaça seja "sensível”, quanto à possível redução ou perda da diversidade biológica. Ameaça sensível é aquela revestida de perceptibilidade ou aquela considerável ou apreciável (MACHADO, 2007).

A partir desse alicerce inicial, as ameaças foram agrupadas segundo sua origem. Por exemplo, todos os problemas decorrentes de práticas agrícolas inadequadas, tais como: erosão, desmatamento, assoreamento, fragmentação etc. foram considerados uma única fonte de ameaça - expansão agrícola. Da mesma maneira foram agrupados os problemas ambientais decorrentes da expansão urbana.

As ameaças assim agrupadas foram estudadas em campo e avaliadas comparativamente segundo o seu grau de importância, quer seja pelo risco aos ecossistemas naturais, quer seja por ir contra as premissas do desenvolvimento sustentável.

A partir de visitas de campo, os problemas existentes, listados a seguir, foram submetidos à avaliação de importância para o presente estudo (Fig.3 do anexo A).

- presença de animais exóticos que invadem a unidade de conservação a partir das propriedades do entorno; 
- $\quad$ presença de uma linha de transmissão de energia que atravessa a zona tampão e margeia os limites da unidade;

- $\quad$ existência de um depósito de entulho (restos de construção civil e assemelhados);

- expansão da monocultura canavieira, substituindo áreas de pastagens;

- $\quad$ expansão urbana, com loteamentos sendo abertos em áreas cada vez mais próximas do perímetro da unidade;

- $\quad$ aterro sanitário próximo ao perímetro da unidade de conservação;

- $\quad$ duas rodovias que margeiam a unidade de conservação;

- $\quad$ condomínios de chácaras já instalados no interior da zona tampão;

- $\quad$ distrito Industrial (indústrias secas) no interior da zona tampão;

- $\quad$ pedreira desativada junto à divisa da unidade; $\mathrm{e}$

- $\quad$ linha férrea no interior da zona tampão.

Estabeleceram-se critérios para avaliação das ameaças elencadas, com base nos riscos oferecidos à saúde pública e aos recursos naturais, na urgência ou possibilidade de solução e na existência de possíveis conflitos jurídicos, que apontem para a necessidade de mudanças nos instrumentos legais que regem a questão.

Os critérios e indicadores utilizados na avaliação e a respectiva pontuação são explicados a seguir:

\section{Possibilidade de evitar ou resolver}

Partindo-se do princípio de que devem ser prioritários os conflitos que podem ser evitados mediante ações adequadas de manejo e gestão ou para os quais podem ser apontadas soluções, os 
problemas foram assim classificados:

3: Problemas iminentes que podem ser evitados;

2: Problemas existentes que podem ser removidos ou solucionados;

1: Problemas existentes cujo impacto pode ser minimizado;

0: Problemas existentes que não podem ser removidos ou solucionados.

\section{Número de pessoas afetadas ou envolvidas}

Os problemas foram hierarquizados, considerando-se que a importância do problema é proporcional ao número de pessoas por ele afetadas:

2: Grande número de pessoas diretamente afetadas ou envolvidas;

1: Pequeno número de pessoas diretamente afetadas ou envolvidas;

0: Não afeta seres humanos.

\section{Ameaça à saúde pública}

Atribuiu-se maior prioridade a focos de conflito que oferecem risco à saúde humana:

2: Risco elevado para grande número de pessoas;

1: Risco elevado para pequeno número de pessoas;

0: Baixo ou nenhum risco à saúde pública.

\section{Riscos para o ecossistema natural}

Maior prioridade foi dada aos problemas que colocam em risco a sobrevivência de espécies raras ou ameaçadas:

2: Oferece ameaça a espécies raras;

1: Oferece ameaça a espécies abundantes;

0: Não oferece ameaça direta à fauna silvestre ou à vegetação nativa. 


\section{Existência de conflito jurídico}

Considerando-se que devem ser prioritariamente analisados os conflitos que envolvem um maior número de institutos jurídicos e, portanto, precisam de maior esclarecimento:

2: Envolve mais de um instituto jurídico;

1: Envolve pelo menos um instituto jurídico;

0: Sem conflito jurídico aparente.

Para cada ameaça, efetuou-se o somatório da nota atribuída a cada um dos indicadores, multiplicada pelo peso atribuído ao respectivo indicador. A hierarquização das ameaças se fez com base no valor obtido neste somatório.

Dentre as atividades da zona tampão da Estação Ecológica de Assis, aquelas consideradas mais importantes foram analisadas, com base nos problemas a elas associados e nas leis sobre elas incidentes.

\subsection{RESULTADOS E DISCUSSÃO}

Os mais importantes conflitos de uso, dentro da zona tampão da Estação Ecológica de Assis, em ordem decrescente de importância para a orientação de ações de manejo e gestão, foram os seguintes: expansão urbana, aterro sanitário, expansão agrícola, invasão por animais exóticos e depósito de entulho (Tabela 1). 
Tabela 1 - Avaliação comparativa da importância das ameaças oriundas da zona tampão da Estação Ecológica de Assis, SP, para as decisões de manejo e gestão.

\begin{tabular}{|c|c|c|c|c|c|c|}
\hline \multirow[b]{2}{*}{ Ameaças } & \multicolumn{6}{|c|}{ Indicadores de importância } \\
\hline & $\begin{array}{c}\text { Possibilidade } \\
\text { de evitar ou } \\
\text { resolver }\end{array}$ & $\begin{array}{l}\text { Número } \\
\text { de } \\
\text { pessoas } \\
\text { afetadas }\end{array}$ & $\begin{array}{l}\text { Risco à } \\
\text { saúde } \\
\text { pública }\end{array}$ & $\begin{array}{l}\text { Risco para o } \\
\text { ecossistema }\end{array}$ & $\begin{array}{l}\text { Existência } \\
\text { de conflito } \\
\text { jurídico }\end{array}$ & $\begin{array}{l}\text { Nível de } \\
\text { prioridade }\end{array}$ \\
\hline $\begin{array}{l}\text { 1. Expansão } \\
\text { urbana }\end{array}$ & 3 & 2 & 2 & 1 & 2 & 24 \\
\hline $\begin{array}{l}\text { 2. Aterro } \\
\text { sanitário }\end{array}$ & 3 & 1 & 1 & 1 & 2 & 06 \\
\hline $\begin{array}{l}\text { 3. Expansão } \\
\text { agrícola }\end{array}$ & 3 & 1 & 1 & 1 & 2 & 06 \\
\hline $\begin{array}{l}\text { 4. Animais } \\
\text { exóticos }\end{array}$ & 2 & 1 & 1 & 2 & 1 & 04 \\
\hline $\begin{array}{l}\text { 5. Depósito de } \\
\text { entulho }\end{array}$ & 2 & 1 & 1 & 1 & 1 & 02 \\
\hline 6. Rodovias & 0 & 0 & 1 & 1 & 2 & 0 \\
\hline $\begin{array}{l}\text { 7. Condomínios } \\
\text { existentes }\end{array}$ & 0 & 1 & 1 & 0 & 2 & 0 \\
\hline $\begin{array}{l}\text { 8. Distrito } \\
\text { industrial (CDA) }\end{array}$ & 0 & 1 & 0 & 0 & 2 & 0 \\
\hline 9. Pedreira & 1 & 0 & 0 & 0 & 2 & 0 \\
\hline 10. Ferrovia & 0 & 0 & 0 & 1 & 1 & 0 \\
\hline 11. Linhão & 0 & 0 & 0 & 2 & 1 & 0 \\
\hline
\end{tabular}

As cinco ameaças avaliadas como de maior importância para este estudo, especialmente pelos aspectos jurídicos envolvidos, e as ferramentas que precisarão ser consideradas na busca de solução para minimizar ou eliminar cada uma delas, são apresentadas e discutidas a seguir. 
Cada uma das atividades que oferecem ameaça aos recursos naturais foi analisada, do ponto de vista jurídico, primeiro, quanto à exigência ou não de licenciamento e, segundo, quanto à possibilidade de remoção para outro local. O primeiro critério é essencial, pois, se a atividade depender de licenciamento para ter continuidade, o órgão gestor da unidade deverá ser ouvido antes da emissão da licença. Em conseqüência disso, o Instituto Florestal (IF) poderá emitir parecer que impeça a continuidade da ação. Porém, caso o órgão licenciador não siga as recomendações do órgão gestor da unidade, a recomendação resultará inócua.

\subsubsection{Expansão urbana}

A zona tampão da Estação Ecológica de Assis delimita-se com alguns núcleos de expansão urbana da cidade de Assis (Fig.4), todos situados na bacia hidrográfica que fornece água para abastecimento urbano. Um dos efeitos causados pela urbanização desordenada é a perda da biodiversidade, com reflexos na flora, fauna, perda de hábitat, fragmentação e homogenização (PAUCHARD et al., 2006). Segundo esse autor, a expansão urbana sem planejamento acarreta também a impermeabilização do solo, levando à diminuição do armazenamento de água no lençol freático, colocando assim em risco o abastecimento à população Acontece que a expansão urbana, na maioria das vezes, tem ocorrido em torno dos sistemas aquáticos, afetando com isso suas qualidades biológicas e físicas (PAUCHARD et al., 2006).

Desse modo, a urbanização implica ampliação da rede de esgotos, aumento da disposição de lixo e uma série de outras conseqüências indesejáveis para a qualidade da água em uma área de abastecimento de manancial (Figuras.5 e 6). Por isso, a possibilidade de expansão urbana para o interior da zona tampão oferece ameaça especialmente à população humana, mais até do que 
sobre os recursos naturais da unidade de conservação.

A urbanização desordenada vem sendo objeto de discussão em diferentes esferas. Diante do colapso ambiental existente cabe aos gestores municipais, necessariamente, considerar variáveis biológicas ao planejar e executar a política de desenvolvimento urbano (PAUCHARD et al., 2006).

Analisando-se a possibilidade de expansão urbana sobre a zona tampão de unidades de conservação, do ponto de vista jurídico, novamente a ferramenta inicial que deve ser considerada para sua contenção é a Lei $n^{\circ}$. 9.985/00 que instituiu o Sistema Nacional de Unidades de Conservação - SNUC ${ }^{16}$ (PINTO; WINDT; SIQUEIRA, 2001). Diz a Lei que a área de uma unidade de conservação do Grupo de Proteção Integral é considerada zona rural, para os efeitos legais (artigo. 49) ${ }^{17}$. Além disso, dispõe o parágrafo único do mesmo dispositivo que após a Zona de Amortecimento ser definida formalmente ela não poderá ser transformada em zona urbana.

A contenção da expansão da zona urbana sobre a área rural será efetiva a partir do devido ordenamento do uso territorial municipal. Este ordenamento pode inibir, além dos conflitos de interesse de uso decorrentes da expansão urbana, outros tais como o aterro sanitário e o depósito de entulho, no caso da Estação Ecológica de Assis. Portanto, as soluções para esses conflitos passam pela implementação adequada e eficiente de alguns instrumentos da política de

\footnotetext{
${ }^{16}$ Cabe ressaltar que no Estado de São Paulo não há previsão legal sobre o Sistema Estadual de Unidades de Conservação (SEUC). Diferentemente de outros Estados tais como: Ceará, Paraíba e Rio Grande do Sul que possuem o SEUC. Em 18 de outubro de 2006 a Comissão de Biodiversidade, Florestas e Áreas Protegidas realizou uma reunião para discutir o Projeto de Lei 289/06 que trataria do SEUC no Estado de São Paulo, porém os membros da Comissão entenderam que ela somente reproduziu a legislação federal, não dispondo sobre a gestão das unidades de conservação.

17 A formalidade exigida pelo art.49 da Lei $\mathrm{n}^{\text {o. }}$ 9.985/00 é a publicação do reconhecimento da Zona de Amortecimento no CONSEMA (Conselho Estadual do Meio Ambiente). Recomenda-se que o CONSEMA encaminhe uma carta para a Prefeitura, comunicando sobre a Deliberação de que reconheceu a existência da Zona de Amortecimento da unidade.
} 
desenvolvimento urbano municipal, tais como: Plano Diretor, Código de Obras, Lei Orgânica, Lei de Uso e Ocupação do Solo, Lei de Parcelamento do Solo Urbano - Lei n ${ }^{\circ}$ 6.766/79 (BRASIL, 1979b), Estatuto da Cidade - Lei nº. 10.257/01 (BRASIL, 2001a) Conselho de Desenvolvimento Urbano e COMDEMA (Conselho Municipal de Defesa do Meio Ambiente), além da atuação do Ministério Público e de outros atores institucionais que exercem os instrumentos de comando e controle no ordenamento jurídico e na esfera administrativa.

Com exceção da Lei de Uso e Ocupação do Solo, os demais instrumentos foram incorporados pelo Plano Diretor de Assis, que foi instituído pela Lei Complementar $\mathrm{n}^{\mathrm{o}}$. 10/06 (PREFEITURA MUNICIPAL DE ASSIS, 2006), a qual propôs uma série de ferramentas objetivando atingir o desenvolvimento sustentável do município. A elaboração do Plano Diretor para cidades com mais de vinte mil habitantes é previsto constitucionalmente pelo art. 182, caput, $\S 1^{\circ}, 2^{\circ}$ (BRASIL, $1988^{18}$ ). Porém, a aplicação desse instrumento não é tarefa fácil e a sua concretização depende de ações e decisões políticas, que na maioria das vezes colidem com interesses econômicos divergentes.

Procurando-se no Plano Diretor do município de Assis instrumentos que sirvam para inibir a expansão urbana sobre a Zona de Amortecimento da EEcA, encontram-se itens distintos. O Capítulo I trata da questão do desenvolvimento rural e dispõe sobre o macrozoneamento e o zoneamento (Título III). Neste Capítulo o Plano Diretor (PREFEITURA MUNICIPAL DE ASSIS, 2006) procurou atender às exigências da Lei Federal no . 10.257/01 (BRASIL, 2001a), que instituiu o Estatuto da Cidade, o qual estabelece diretrizes gerais da política urbana. Além disso, os artigos. 37, 38 e 39 dispõem sobre as normas de macrozoneamento e sobre as regras

\footnotetext{
${ }^{18}$ Art. $182, \S 1^{\circ} \mathrm{O}$ plano diretor, aprovado pela Câmara Municipal, obrigatório para cidades com mais de vinte mil habitantes, é o instrumento básico d apolítica de desenvolvimento e de expansão urbana. $\$ 2^{\circ}$ A propriedade urbana cumpre sua função social quando atende às exigências fundamentais de ordenação da cidade expressas no plano diretor.
} 
fundamentais de ordenação do território no município (PREFEITURA MUNICIPAL DE ASSIS, 2006).

Dentre as normas de macrozoneamento, merece destaque o artigo $39^{19}$ (PREFEITURA MUNICIPAL DE ASSIS, 2006), pois se houver efetivamente o seu cumprimento, a integridade da Zona de Amortecimento será preservada. Dispõe o artigo. 39, inciso III: a contenção da expansão da área urbana na região da Zona de Amortecimento da Estação Ecológica de Assis e em regiões que acarretem degradação sócio-ambiental (PREFEITURA MUNICIPAL DE ASSIS, 2006).

$\mathrm{O}$ art. $42^{20}$, caput do Capítulo II do Plano disciplina a composição da macrozona rural, dividindo-a em: áreas de uso agrícola, florestal, pecuário, áreas com outros usos, como chácaras de recreio, lazer, turismo, comércio e indústria e áreas cobertas por vegetação natural, Unidades de Conservação da natureza, Áreas de Preservação Permanente e Reserva Legal nas propriedades rurais (PREFEITURA MUNICIPAL DE ASSIS, 2006).

No art.42, $\S 1^{0^{21}}$ foi feita a subdivisão da macrozona rural e no inciso IV criou-se a zona agrosilvopastoril, que foi assim definida: demais áreas da zona rural, inclusive área da Floresta Estadual de Assis (FEA) e a Zona de Amortecimento da Estação Ecológica de Assis, destinadas à produção agrosilvopastoril. Na mesma linha de raciocínio, o inciso $\mathrm{V}$ instituiu a zona de conservação da natureza, que compreende todas as áreas com vegetação natural remanescente, incluída a Estação Ecológica de Assis, as Áreas de Preservação Permanente e as Reservas

\footnotetext{
${ }^{19}$ Art. 39, caput, - O macrozoneamento tem como objetivo o ordenamento territorial do município de forma a permitir.

${ }^{20}$ Art. 42. A Macrozona Rural é composta por áreas de uso agrícola, florestal ou pecuário, por áreas com outros usos como chácaras de recreio, lazer, turismo, comércio, e indústrias e áreas cobertas por vegetação natural, compreendendo unidades de conservação da natureza, áreas de preservação permanente e reservas legais das propriedades.

${ }^{21}$ Art. $42, \S 1^{\circ}$ - A Macrozona Rural divide-se em.
} 
Legais obrigatórias das propriedades rurais (PREFEITURA MUNICIPAL DE ASSIS, 2006).

Também tratando do assunto, o artigo. 43 determinou que a criação de novas áreas de expansão urbana dentro da Zona de Amortecimento da Estação Ecológica de Assis, dependerá de prévia anuência do órgão gestor da Unidade de Conservação e do Conselho de Desenvolvimento Urbano (PREFEITURA MUNICIPAL DE ASSIS, 2006).

Uma falha a ser apontada é que o artigo. 43 não fez nenhuma menção ao COMDEMA e se caberia a este conselho se posicionar sobre novas áreas de expansão urbana dentro da Zona de Amortecimento (PREFEITURA MUNICIPAL DE ASSIS, 2006). Além disso, o Plano Diretor da PREFEITURA MUNICIPAL DE ASSIS (2006) em seu artigo. 17, inciso XI ${ }^{22}$ não dispõe sobre as atribuições do órgão, ou seja, se poderá deliberar sobre as questões ou se somente possuirá poder consultivo. Para suprimir esta falha, a solução deverá ser a instituição de lei complementar, mencionando os objetivos do COMDEMA, sua composição e suas atribuições.

Outro dispositivo que restringe a expansão urbana sobre a Zona de Amortecimento, dentro do Plano Diretor, é o artigo $65, \S 1^{023}$, o qual disciplina as Áreas de Especial Interesse Ambiental e os diferentes níveis de restrição de uso do solo (PREFEITURA MUNICIPAL ASSIS, 2006).

De modo geral, os trechos citados do Plano Diretor do município de Assis demonstram que o Plano de Manejo e suas determinações foram respeitadas.

O Plano Diretor tem prioridade sobre outros planos existentes no Município ou que

\footnotetext{
${ }^{22}$ Art. 17 - São consideradas ações prioritárias que devem ser implementadas para garantir a preservação do meio ambiente ecologicamente equilibrado: XI - Assegurar o funcionamento do Conselho Municipal de Defesa do Meio Ambiente (COMDEMA).

${ }^{23}$ Art. 65 - As Áreas de Especial Interesse Ambiental apresentarão diferentes níveis de restrição do uso do solo e dos recursos naturais nela existentes, indo desde a proibição do uso até a permissão para manejo ou , nas áreas de domínio público, para uso recreativo, educativo ou turístico. $\S 1^{\circ}$ - Toda atividade ou ocupação que esteja contida na Zona de Amortecimento da Estação Ecológica de Assis será submetida à análise do órgão gestor daquela unidade de conservação.
} 
possam vir a ser instituídos. A acepção “diretor” tem dimensão jurídica considerável, pois é um plano criado pela lei para dirigir e para fazer com que os demais ordenamentos municipais, tais como: leis, decretos e portarias anteriores ou posteriores tenham de se ajustar ao Plano Diretor (MACHADO, 2007). O Plano Diretor é uma lei municipal, pois os planos urbanísticos importam inovação de grande profundidade no ordenamento jurídico, impondo obrigações e constrangimentos e gerando direitos que, no sistema brasileiro, somente se compreendem mediante lei (SILVA, 2006).

O Plano de Manejo possui a natureza jurídica de um documento de gestão técnicoadministrativa e foi instituído pelo art. $2^{\circ}$, inciso XVII e art.27, $\S 1^{\circ}, \S 2^{\circ}$ e $\S 3^{\circ}$ da Lei $n^{\circ} .9 .985 / 00$ (PINTO; WINDT; SIQUEIRA, 2001). Este documento é hierarquicamente inferior ao Plano Diretor do município, que é um instrumento técnico de planejamento urbano previsto constitucionalmente pelo art.182 (BRASIL, 1988). O Plano Diretor faz parte da política urbana a ser desempenhada pelo município, propondo o ordenamento do uso do solo municipal.

O primeiro documento serve para a unidade de conservação ordenar o uso do solo (estabelecendo o zoneamento na unidade) e propor o manejo que será realizado no ecossistema protegido e em sua zona tampão. O Plano Diretor deve obrigatoriamente tratar da zona urbana e rural dos municípios e pondera Machado (2007), se o Plano Diretor não dispuser sobre a área rural, este estará contaminado e poderá ser pedida a sua nulidade ${ }^{24}$.

Cabe ressaltar, também, que o município não deverá planejar visando somente a sua realidade política, social e econômica, mas haverá de ter em conta o ecossistema em que está inserido, especialmente a bacia e sub-bacia hidrográfica de que faz parte. Consistiria em uma

\footnotetext{
${ }^{24}$ O Estatuto da Cidade (Lei $\mathrm{n}^{\mathrm{o}}$. 10.257/01) dispõe: Art. 40. O plano diretor, aprovado por lei municipal, é o instrumento básico da política de desenvolvimento e expansão urbana. § $\mathbf{2}^{\mathbf{0}} \mathrm{O}$ plano diretor deverá englobar o território do Município como um todo.
} 
aberração jurídica e ecológica deixar o plano diretor municipal de se adaptar às diretrizes do plano de bacia hidrográfica (MACHADO, 2007).

Do ponto de vista jurídico, pode-se considerar que, especialmente pela inserção do tema no Plano Diretor do município, a expansão urbana sobre a Zona de Amortecimento da Estação Ecológica de Assis poderá ser evitada, dependendo, portanto, da fiscalização e aplicação das leis vigentes.

\subsubsection{Aterro sanitário}

Existem pesquisas ressaltando os problemas ambientais e de saúde pública decorrentes da existência de um aterro sanitário (POSSAMAI et al., 2007; SISINNO; MOREIRA, 1996), destacando-se: incômodo a vizinhança, poluição do ar e de compartimentos ambientais (águas superficiais, subterrâneas, solos e sedimentos), além da proliferação de vetores de doenças (Fig.7).

Segundo Hamada (1999), ao destacar o aspecto de poluição das águas, ressalta que: "nos lixões o chorume é um dos principais elementos impactantes, sendo originado na decomposição da matéria orgânica contida no lixo, associada aos líquidos percolados ali existentes”.

Outro fator que pode agravar a poluição ambiental é a permeabilidade do solo sob o aterro. Se o solo sob o aterro for permeável, há a possibilidade de o chorume atingir o lençol freático, causando a poluição desse recurso hídrico (POSSAMAI et al., 2007).

Dentre os vários aspectos ambientais que podem ser realçados, destaca-se às altas concentrações de metais pesados que podem ser encontrados em lixões, aterros controlados e sanitários. Alguns dos metais encontrados por estudos já desenvolvidos em aterros de lixo são: Cádmio, Cromo, Cobre, Ferro, Manganês, Chumbo e Zinco (OLIVEIRA; JUCÁ, 2004; 
SISINNO; MOREIRA, 1996) .

O aterro sanitário de Assis foi criado com a função de receber o excedente do material do Parque de Reciclagem e Compostagem de Lixo. Localiza-se na nascente da Água da Roça ou da Pontinha, às margens da Rodovia SP-333, e foi considerado o mais grave problema ambiental no entorno da Estação Ecológica de Assis, quando da elaboração do Plano de Desenvolvimento Sustentável para o Entorno da Estação Ecológica de Assis (MAX et al., 2004a).

Os riscos representados pelo aterro para a Estação dizem respeito à qualidade do manejo utilizado no local e à sua extensão, que poderão gerar problemas futuros à área de expansão prevista para a Estação Ecológica. O manejo inadequado do lixo depositado no aterro compromete a qualidade da água que abastece várias propriedades rurais, que, por estarem situadas a jusante do aterro, podem estar sendo contaminadas (MAX et al., 2004a).

Do ponto de vista ecológico, a existência do aterro pode acarretar ameaças ao equilíbrio das populações e aos processos ecológicos no local do aterro e para espécies que de deslocam dali para a Estação Ecológica. A existência do aterro, além de acarretar riscos ao meio ambiente, também representa risco potencial à saúde pública. Os moradores vizinhos ao local ficam expostos a vetores de doenças, insetos e animais peçonhentos. Os vetores de doenças são tanto os macrovetores (cachorros, gatos, ratos, urubus, pombos e outros), como os microvetores, tais como: moscas, mosquitos, bactérias, fungos e outros (SISINNO; MOREIRA, 1996).

Diante do exposto, surgem alguns questionamentos preliminares sobre o aterro: i) se a sua existência no local é compatível com os objetivos de uma Unidade de Conservação de Proteção Integral; ii) se existe fiscalização e garantia de que o aterro somente receba o excedente do Parque de Reciclagem e Compostagem de Lixo; iii) se o local realmente pode ser classificado como um Aterro Sanitário. 
Quanto à primeira pergunta, no caso deste aterro localizado na Zona de Amortecimento da EEcA, a resposta é não. Antes de uma área ser selecionada para servir de aterro sanitário, ela deverá obrigatoriamente seguir determinados critérios técnicos impostos pelas normas da Associação Brasileira de Normas Técnicas - ABNT (1992) e pela legislação Federal, Estadual ou Municipal. Dentre as imposições e limitações referentes às normas da ABNT, o primeiro critério técnico refere-se ao uso do solo. Assim, as áreas têm de ser alocadas onde o uso do solo seja rural ou industrial e fora de qualquer Unidade de Conservação (grifo nosso).

Referente à segunda pergunta a resposta também é negativa. Pela pesquisa realizada no acervo da biblioteca da Floresta Estadual de Assis, foram encontradas várias notícias de jornais locais do ano de 2002, que demonstraram a presença de materiais recicláveis dispostos indevidamente no aterro. Portanto, nessa ocasião o Parque de Reciclagem e Compostagem de Lixo não estava cumprindo sua função conforme fora originalmente designada.

As reportagens dos jornais locais destacaram também a morte de animais pertencentes a proprietários vizinhos ao aterro, os quais supostamente haviam morrido pela ingestão de materiais plásticos dispostos indevidamente no local. Outra reclamação feita pelos moradores quanto ao aterro referia-se ao sistema de transporte do lixo até o local, pois, segundo as reportagens, os proprietários vizinhos relataram que os caminhões responsáveis pelo transporte do lixo trafegavam pela estrada com a carga desprotegida e muitas vezes caíam de seu interior um grande volume de lixo no acostamento e na pista.

Como anteriormente descrito, nas etapas iniciais desta pesquisa foi realizado o estudo de campo com a visita aos locais dos principais pontos de ameaça aos recursos naturais da zona tampão da Estação Ecológica de Assis. No primeiro semestre de 2005, o aterro sanitário foi um dos locais visitados, sendo que nessa visita constatou-se uma grande quantidade de lixo exposto a céu aberto e uma quantidade significativa de materiais recicláveis. 
$\mathrm{Na}$ mesma ocasião foi visitado o Parque de Reciclagem e Compostagem de Lixo e entrevistada a funcionária da Prefeitura Municipal responsável pela limpeza pública. A entrevistada alegou problemas de operacionalização do aterro e que a falta de dados que possibilitassem o planejamento (volume de lixo e despesas) eram "heranças" da gestão anterior.

Para o último questionamento a resposta também é negativa. Um aterro para ser classificado como sanitário deve conter necessariamente algumas instalações básicas, tais como: unidades operacionais, células de lixo domiciliar, células de lixo hospitalar, caso o município não disponha de incinerador, impermeabilização de fundo (obrigatória) e superior (opcional), sistema de coleta e tratamento dos líquidos percolados (chorume), captação de gases, entre outros. Isso tudo forma um conjunto que protege solo, rios, lençóis freáticos e a atmosfera. Ademais, devem existir unidades de apoio consistentes, compreendendo: cerca e barreira vegetal, estradas de acesso e de serviço, balança rodoviária e sistema de controle de resíduos, guarita de entrada e prédio administrativo, oficina e borracharia (MONTEIRO et al., 2001).

Geralmente esses itens descritos não são cumpridos em sua totalidade pelos municípios, em razão do alto custo operacional que representam e o município de Assis não foge a esta regra. $\mathrm{Na}$ visita de campo realizada verificou-se a existência de guarita, porém não havia nenhum funcionário responsável por fiscalizar e controlar a entrada e permanência de pessoas ou de caminhões no local.

Em um aterro sanitário também é proibida a permanência de catadores de lixo. No entanto, na ocasião da visita havia vários catadores, que faziam coleta de materiais recicláveis sem serem perturbados.

O aterro de Assis deveria ser classificado como lixão, pois não possui o essencial que o classificaria como um aterro sanitário, isto é, coleta e tratamento do chorume, drenagem e queima do biogás, além da impermeabilização de fundo das valas. 
Mesmo descumprindo essas determinações, o aterro recebeu uma avaliação positiva quando do Inventário Estadual de Resíduos Sólidos Domiciliares, documento este elaborado pela Companhia de Tecnologia e Saneamento Ambiental (CETESB, 2006). Nesse documento são reproduzidas as condições em que se encontram os sistemas de disposição e tratamento de resíduos sólidos domiciliares em operação, partindo da obtenção de dados e elementos recolhidos e firmados em cada um dos 645 municípios estaduais paulistas.

A responsabilidade pelas informações relacionadas ao município de Assis fica a cargo da Agência CETESB de Marília. Conforme o Inventário elaborado pela CETESB, o município de Assis produz 36 toneladas de lixo por dia, dado este divergente da informação fornecida pela funcionária municipal (responsável pela limpeza pública), de que o lixo gerado por dia em Assis seria da ordem de 55 a 60 toneladas. Mesmo com todas as irregularidades descritas, este aterro sanitário foi classificado pelo Inventário como adequado, recebendo a letra $\mathbf{A}$ (grifo nosso).

De maneira positiva destacam-se as recomendações do Instituto Florestal, constantes no processo de licenciamento, para que o aterro não permaneça no local. Tais recomendações foram consideradas quando da elaboração do Plano Diretor do município. Com isso, o órgão gestor da unidade de conservação conseguiu demonstrar sua força em impedir a permanência dessa atividade impactante na Zona de Amortecimento da Estação Ecológica.

O primeiro dispositivo destacado que segue as recomendações do IF refere-se à criação das Áreas de Especial Interesse, que se encontram inseridas nas Macrozonas. De acordo com o art.59, caput $^{25}$, estas áreas compreendem as porções do território que exigem tratamento

\footnotetext{
25 Art. 59, caput. As Áreas de Especial Interesse encontram-se inseridas nas Macrozonas e compreendem as porções do território que exigem tratamento diferenciado por apresentarem determinadas especificidades, pois cumprem importantes funções no planejamento e no ordenamento do território classificando-se em: II - Área de Especial Interesse Ambiental.
} 
diferenciado, por apresentarem determinadas especificidades, pois cumprem importantes funções no planejamento e no ordenamento do território (PREFEITURA MUNICIPAL DE ASSIS, 2006) No entanto, para a presente pesquisa a Área relevante é a de Especial Interesse Ambiental, o qual está disposto pelo art.59, inciso II (PREFEITURA MUNICIPAL DE ASSIS, 2006).

O segundo dispositivo é o art. $64^{26}$ e incisos, que determinam os objetivos das Áreas de Especial Interesse Ambiental. Complementa o assunto o art.65 ${ }^{27}, \S 1^{\circ}$ e $\S 2^{\circ}$ (PREFEITURA MUNICIPAL DE ASSIS, 2006), que dispõe que:

$\S \mathbf{1}^{\mathbf{0}}$ - Toda atividade ou ocupação que esteja contida na Zona de Amortecimento da Estação Ecológica de Assis será submetida à análise do órgão gestor daquela unidade de conservação.

$\S \mathbf{2}^{\mathbf{0}}$ - O atual Aterro Sanitário Municipal, localizado no interior da Zona de Amortecimento da Estação Ecológica de Assis, terá o seu funcionamento encerrado assim que se esgotarem as possibilidades de sua utilização, implementando-se o processo de sua recuperação ambiental.

Portanto, o Plano Diretor - PREFEITURA MUNICIPAL DE ASSIS (2006)

finalizou a questão, considerando o aterro sanitário municipal atual e os anteriores já desativados como Áreas de Especial Interesse Ambiental (art.66, § $\left.1^{\mathbf{0}}\right)^{\mathbf{2 8}}$. Sabe-se de antemão que os problemas decorrentes da existência de um aterro em uma área não se esgotam com o seu encerramento. A recuperação do local demandará dos gestores municipais recursos financeiros de

\footnotetext{
${ }^{26}$ Art. 64 - As Áreas de Especial Interesse Ambiental são porções do território municipal destinadas a: I - proteger e recuperar os mananciais, nascentes e cursos d'água; II - preservar áreas com vegetação significativa e com paisagens naturais notáveis; III - preservar áreas de reflorestamento ou de fragmentos vegetais nativos; IV conservar parques ecológicos e fundos de vale; $\mathrm{V}$ - recuperar as áreas ambientalmente degradadas.

${ }^{27}$ Art. 65, caput. As Áreas de Especial Interesse Ambiental apresentarão diferentes níveis de restrição do uso do solo e dos recursos naturais nela existentes, indo desde a proibição do uso até a permissão para manejo ou, nas áreas de domínio público, para uso recreativo, educativo ou turístico.

${ }^{28}$ Art. 66, caput. As áreas consideradas de Especial Interesse Ambiental, localizadas na zona urbana, são aquelas constantes no Anexo 4, integrante desta Lei. $\S 1^{\circ}$ - São consideradas Áreas de Especial Interesse Ambiental: o Aterro Sanitário Municipal atual e os desativados, os Cemitérios e as Estações de Tratamento de Esgotos. Observação: O Anexo 4 estabelece que as Áreas de Especial Interesse Ambiental localizadas na zona urbana são as seguintes: Áreas de Especial Interesse Social, Industrial, Ambiental, Histórico-Cultural e Institucional.
} 
grande monta, comprometimento e vontade política de governantes realmente engajados com a implementação de políticas públicas municipais relacionadas à gestão dos resíduos sólidos urbanos e, ainda, a criação e aplicação de novos instrumentos que assegurem o desenvolvimento efetivo e pleno das cidades no caminho da sustentabilidade de fato, prevista pelo Estatuto da Cidade.

Além do Plano Diretor, que parece ser a ferramenta mais adequada para tratar do assunto, pode-se entender que a existência do aterro sanitário próximo aos limites da Estação Ecológica contraria o dispositivo constitucional que assegura o direito da coletividade ao meio ambiente ecologicamente equilibrado (CF, art.225 - BRASIL, 1988). Além disso, também é vedada ao Poder Público qualquer utilização das áreas protegidas que comprometa a integridade dos atributos justificadores de sua proteção (CF, art.225, inciso III - BRASIL, 1988).

O consentimento da permanência do aterro na Zona de Amortecimento fere também o art.23, incisos VI e VII ${ }^{29}$ (BRASIL, 1988), o qual confere competência comum da União, dos Estados, do Distrito Federal e dos Municípios, de proteger o meio ambiente e combater a poluição em qualquer de suas formas, além de preservar as florestas, a fauna e a flora.

Outra questão correlata ao aterro é o chamado uso nocivo da propriedade. Poderia este dispositivo ser utilizado para fundamentar a saída do aterro do local? Segundo Alves (1992), o direito ambiental visa à tutela jurídica das populações e o Direito Civil resguarda o direito da vizinhança ao sossego, ao ar, à água e ao solo livres da contaminação. A diferença essencial entre ambas as disciplinas consistiria no maior alcance do Direito Ambiental, que não se limitaria à vizinhança.

O uso normal da propriedade é um instituto de caráter civilista, amplamente utilizado nas

\footnotetext{
${ }^{29}$ Art. 23. É competência comum da União, dos Estados e do Distrito Federal e dos Municípios: VI - proteger o meio ambiente e combater a poluição em qualquer de suas formas; VII - preservar as florestas, a fauna e a flora.
} 
questões relacionadas ao direito de vizinhança, de aplicação na esfera do direito privado. Conforme o dispositivo 1.277, do Código Civil (BRASIL, 2002a), o proprietário ou o possuidor de um prédio tem o direito de fazer cessar as interferências prejudiciais à segurança, ao sossego e à saúde dos que o habitam, provocadas pela utilização de propriedade vizinha. No entanto, outra dúvida que paira é se tal preceito pode ser utilizado na regulamentação das atividades efetuadas dentro da zona tampão, que são conflitantes para o equilíbrio do ecossistema protegido pela unidade.

O uso nocivo da propriedade pode ser alegado somente pelo particular, para requerer que o município remova o aterro ou outro tipo de depósito de lixo municipal para outro local. Neste aspecto, conforme realçam Nery Junior e Nery (2002), existe jurisprudência do Superior Tribunal de Justiça, que legitima os particulares a ingressarem com ação judicial sem serem representados pelo Ministério Público.

\subsubsection{Expansão agrícola}

A expansão agrícola e o desenvolvimento das atividades agropecuárias representam uma séria ameaça à biodiversidade da Estação Ecológica. Os impactos ambientais causados pelas atividades agropecuárias sobre a biodiversidade, de modo geral, podem incluir: desmatamento e expansão da fronteira agrícola; queimadas em pastagens e florestas, poluição por dejetos animais e agrotóxicos, erosão e degradação de solos e contaminação das águas, entre outros (RODRIGUES, 2001; FISZON et al., 2003;).

Porém, os impactos também acarretam conseqüências para o hábitat, com a extinção de espécies, populações e ecossistemas, diminuição da diversidade intra-específica, perda de variabilidade genética, entre outras (RODRIGUES, 2001). 
Ocorre que grande parte da biodiversidade terrestre está inserida em ambiente agrícola, ou seja, cerca de 90\% dessa diversidade encontra-se em áreas intensiva ou extensivamente exploradas por atividades econômicas (PIMENTEL et al., 1992). Por essa razão, o manejo agrícola conservacionista é fundamental para assegurar uma diminuição da perda da biodiversidade biológica existente (RODRIGUES, 2001).

Pondera Rodrigues (2001) que a expansão da fronteira agrícola não configura uma das principais ameaças da agricultura sobre a biodiversidade. As ameaças estariam sim representadas pela preponderância e avanço da agricultura intensiva - a tendência à monocultura e o uso de pesticidas - além da conseqüente extinção de sistemas tradicionais de cultivo. Prossegue ainda o autor que as conseqüências do modelo agrícola utilizado no Brasil e em outros países são muitas e abrangem várias facetas, tais como: degradação do meio ambiente e dos recursos naturais, acarretando desde danos indiretos à biodiversidade até a ocupação e destruição de hábitats e extinção de espécies.

No Estado de São Paulo, Kronka et al. (1998) demonstraram que houve diminuição alarmante nas áreas cobertas por vegetação de cerrado, com perda de $87 \%$ da área no período 1962 a 1992. O mesmo estudo mostra que a região de Governo de Assis apresentou redução de 76\% nas diversas categorias de cerrado no período de 1962 até 1992, porcentagem ligeiramente inferior à do estado como um todo. A ocupação do solo na região pela cultura da cana-de-açúcar sofreu um aumento de área da ordem de $637 \%$, enquanto a cultura temporária cresceu $88 \%$ naquele período.

No caso da região de Assis, especialmente no uso do solo ao redor dos fragmentos florestais da EEcA, a mais freqüente mudança constatada tem sido a substituição das pastagens pela cana-de-açúcar (MAX et al., 2004a). As ameaças aos recursos naturais da unidade de conservação derivadas dessa mudança compreendem: diminuição da permeabilidade da 
paisagem, pois as pastagens com árvores isoladas funcionam como extensão do hábitat de cerrado para boa parte da fauna. Na mudança para agricultura, geralmente são eliminadas todas as plantas lenhosas. Há aumento na aplicação de agrotóxicos e aumento nos riscos de erosão e, no caso específico da cultura canavieira, o uso regular do fogo é uma ameaça adicional importante.

A conversão de pastagens em agricultura oferece, portanto, ameaça à biodiversidade e aos recursos hídricos, embora essa ameaça não seja tão evidente e não atinja diretamente a população humana.

O único instrumento jurídico correlato à expansão da agricultura dentro da zona tampão de unidades de conservação o faz de maneira indireta, ao estabelecer a necessidade de que o órgão gestor da unidade seja ouvido nos processos de licenciamento (Resolução CONAMA 13/90 - BRASIL, 1990b). Regra geral, a mudança de uso da terra não tem passado pela esfera jurídica, dependendo apenas da vontade do proprietário. O licenciamento ambiental tem sido considerado necessário quando a conversão depende do corte de árvores isoladas e, conforme demonstrado no capítulo 2 deste estudo, esta tem sido a razão mais freqüente nos pedidos de licenciamento nas propriedades rurais localizadas na Zona de Entorno da Estação Ecológica de Assis. No entanto, há, aqui, uma falha de interpretação da lei por parte dos gestores, pois existe, sim, respaldo jurídico para que a conversão do uso da terra, nos casos em que seja maléfica para a conservação, passe a ser objeto de licenciamento. Em seu art. $1^{\circ}$, o texto da Resolução CONAMA 13/90 (BRASIL, 1990b) diz que:

Art. $\mathbf{1}^{\mathbf{0}}$ - O Órgão responsável por cada Unidade de Conservação, juntamente com os órgãos licenciadores e de meio ambiente, definirá as atividades que possam afetar a biota da Unidade de Conservação.

Com base no disposto na Resolução, caberia aos gestores a iniciativa de elencar todas as atividades potencialmente impactantes e, entre elas, poderiam ser incluídas formas de uso da terra 
que usualmente não são objeto de licenciamento.

Surge aqui uma nova dúvida: até onde vai a competência do gestor em apontar determinados usos agrícolas entre as atividades que necessitam de licenciamento e, eventualmente, proibir a modificação de uso da terra, por exemplo, de pastagem para cana-deaçúcar? Para que tal decisão não gerasse dúvidas, seria desejável que houvesse comprovação científica dos malefícios que a conversão causaria ao ecossistema natural.

Pode-se aplicar ainda, nesses casos, o princípio constitucional da função social da propriedade, nele incorporando-se uma dimensão ambiental (art.170, inciso III - BRASIL, $1988^{30}$ ), ou seja, o direito à propriedade só é garantido a partir do cumprimento da função social e ambiental do imóvel rural (CF, art.186, incisos I ao IV - BRASIL, 1988 $\left.{ }^{31}\right)$.

As propriedades rurais, porém, também devem atender, concomitantemente, a outros aspectos, como, por exemplo: utilização adequada dos recursos naturais disponíveis e preservação do meio ambiente (CF, art. 186, inciso II - BRASIL, 1988). Cabe ressaltar que o princípio da função social relacionado ao imóvel rural já havia sido anteriormente assegurado pelo Estatuto da Terra - Lei no. 4.504/64 (BRASIL, 1964). Alguns dos dispositivos do Estatuto que ilustram o tema são: art. $2^{\circ}, \S 1^{\circ}$, alíneas a, b, c e d; art. $2^{\circ}, \S 2^{\circ}$, alínea $b^{32}$; art. $12^{33}$; art.13

\footnotetext{
${ }^{30}$ Art. 170 , III - função social da propriedade.

31 Art. 186, caput. A função social é cumprida quando a propriedade rural atende, simultaneamente, segundo critérios e graus de exigência estabelecidos em lei, aos seguintes requisitos: I - aproveitamento racional e adequado; II - utilização adequada dos recursos naturais disponíveis e preservação do meio ambiente; III observância das disposições que regulam as relações de trabalho; IV - exploração que favoreça o bem-estar dos proprietários e trabalhadores.

32 Art. $2^{\circ}$, caput. É assegurada a todos a oportunidade de acesso à propriedade da terra condicionada pela sua função social, na forma prevista nesta Lei. $\S 1^{\circ}$ A propriedade da terra desempenha integralmente a sua função social quando simultaneamente: a) favorece o bem-estar dos proprietários e dos trabalhadores que nela labutam, assim como de sua família; b) mantém níveis satisfatórios de produtividade; c) assegura a conservação dos recursos naturais; d) observam as disposições legais que regulam as justas relações de trabalho entre os que a possuem e a cultivem. $\S 2^{\circ}$ É dever do Poder Público: b) zelar para que a propriedade da terra desempenhe sua função social, estimulando planos para a sua racional utilização, promovendo a justa remuneração e o acesso do trabalhador dos benefícios do aumento da produtividade e ao bem-estar coletivo.

${ }^{33}$ Art. 12. À propriedade privada da terra cabe intrinsecamente uma função social e seu uso é condicionado ao
} 
art.18, alíneas a e $\mathrm{h}^{35}$.

O direito à propriedade é previsto pela Constituição Federal, nos artigos. $5^{\circ}$, inciso XXII e 170, inciso II (BRASIL, 1988), e o exercício do direito de propriedade atrelou-se ao cumprimento do princípio da função social. Com isso, de um direito outrora absoluto, passou-se a ter um direito relativo. Outro subsídio legal importante é o Código Civil, art.1228, § 1º(BRASIL, 2002a), que prevê a obrigatoriedade da propriedade em preservar os recursos naturais e também em cumprir sua função social.

Além disso, as leis não têm sido eficazes nem mesmo nos casos em que a mudança de uso da terra poderia ter sido evitada pela já reconhecida obrigatoriedade legal de ser ouvido o órgão gestor no processo de licenciamento (assunto tratado no capítulo 2).

Constata-se que esta ameaça, ainda que pouco evidente, deve ser alvo, primeiro, de ação imediata dos gestores em, no ato de delimitar a Zona de Amortecimento no Plano de Manejo, estabelecer claramente quais culturas necessitarão de licenciamento para que possam substituir outras culturas menos impactantes já existentes. Outras estratégias de gestão deverão ser adotadas, passando, por exemplo, por programas de educação ambiental e, sobretudo, de incentivo ou fomento a atividades produtivas de baixo impacto, tais como a silvicultura, a fruticultura ou mesmo a pecuária, em bases econômica e ecologicamente sustentáveis.

Para a mitigação da ameaça resultante da expansão agrícola, as soluções passam, portanto, pela esfera jurídica, com a ação do gestor em incluí-la entre as atividades potencialmente impactantes, e pela esfera social, com o envolvimento das comunidades vizinhas, como destacado

bem estar coletivo previsto na Constituição Federal e caracterizado nesta Lei.

${ }^{34}$ Art. 13. O Poder Público promoverá a gradativa extinção das formas de ocupação e de exploração da terra que contrariem sua função social.

${ }^{35}$ A desapropriação por interesse social tem por fim: a) condicionar o uso da terra à sua função social; $h$ ) facultar a criação de áreas de proteção à fauna, à flora ou a outros recursos naturais, a fim de preservá-los de atividades predatórias. 
por Padua, Padua e Cullen Jr (2002).

No caso da zona tampão da Estação Ecológica de Assis, é relatado a seguir um processo específico de licenciamento, com vistas à substituição de pastagem por agricultura, que mereceu detalhamento pela localização da propriedade.

Em 2005, o proprietário ingressou com um pedido de licença no órgão ambiental responsável (Departamento Estadual de Proteção dos Recursos Naturais - DEPRN) para o corte de árvores isoladas, com a finalidade de mudança de uso da terra em sua propriedade. Vale lembrar que o Plano de Manejo da Estação Ecológica está em processo de revisão e, portanto, a Zona de Amortecimento não foi ainda delimitada, mas além de vigorar a Resolução CONAMA nº 13/90 (BRASIL, 1990b), esta propriedade está inserida na Zona de Amortecimento da Floresta Estadual de Assis, cuja delimitação foi aprovada pelo CONSEMA em 2005.

Cumprindo a Resolução, o processo foi remetido para o órgão gestor da unidade (IF), para que este proferisse o seu parecer. O parecer do IF foi desfavorável à concessão da licença pelos seguintes motivos: i) o projeto apresentou falhas técnicas; ii) a área foi uma das indicadas como prioritárias para aquisição, visando à ampliação da Estação Ecológica de Assis, sendo parte da compensação dos danos ambientais decorrentes da Usina Hidroelétrica (U.H. E) de Canoas, assim descrito pelos Autos da Secretaria de Meio Ambiente - SMA n . 45.382/04; iii) o desejo de incorporação dessa área privada pela Estação origina-se da importância de se recuperar a vegetação original anteriormente ali existente. Com isso, completar-se-ia um grande corredor de cerrado, conectando a Estação Ecológica de Assis com outros fragmentos de vegetação nativa e, assim, haveria uma ampliação considerável do hábitat para a fauna; iv) sua incorporação à Estação tem como finalidade atender à Deliberação CONSEMA $n^{\circ}$. 30/99, além do que a aquisição das terras havia sido objeto de laudo elaborado pela Procuradoria Geral do Estado.

O Sistema Nacional de Unidades de Conservação dispõe sobre a compensação ambiental 
no artigo. 36 e prevê: que o empreendedor de obras de significativo impacto ambiental é obrigado a apoiar a implantação e manutenção de unidade de conservação do Grupo de Proteção Integral. Ocorre que até o presente momento não houve acordo entre o dono da referida propriedade e o consórcio da U.H. E Canoas sobre o preço a ser pago pela terra.

Após o parecer do gestor da unidade, o processo foi encaminhado para o DEPRN de Bauru (regional), que não se pronunciou sobre a questão. Portanto, até o presente momento o processo continua em tramitação aguardando pronunciamento do DEPRN de Bauru.

\subsubsection{Invasão por animais exóticos}

Muitas das ameaças analisadas até aqui podem ser resolvidas pelas propostas relatadas por este estudo e incorporadas pelo Plano Diretor, com o intuito de solucionar ou minimizar seus impactos causados ao ambiente. São decisões técnicas a serem incorporadas pelo município no planejamento e ordenamento do espaço territorial urbano e rural, que requerem ações efetivas na esfera política, ambiental, econômica e social, para alcançar a sustentabilidade ambiental.

Diferentemente das outras ameaças, a solução ou mitigação do problema acarretado aos ecossistemas naturais pela invasão por espécies exóticas não pode ser resolvido somente pelas diretrizes impostas pelo Plano Diretor. O documento hábil, em grande parte, para tratar da questão, é o Plano de Manejo, que é previsto legalmente pelo art. $2^{\circ}$, inciso XVII e art. $27, \S 1^{\circ}, \S$ $2^{\circ}, \S 3^{\circ}$ do SNUC (PINTO; WINDT; SIQUEIRA, 2001).

O Plano de Manejo é um documento de gestão e ordenamento do uso do solo a ser aplicado pela unidade para garantir a conservação de espécies e comunidades, além da integridade dos recursos naturais por ela protegidos. A existência de espécies exóticas invasoras é típica de ambientes perturbados por intervenções humanas, que exercem altas pressões aos 
ambientes naturais.

Os problemas da perturbação humana causados ao meio ambiente parecem residir ultimamente em três categorias gerais: uso inapropriado dos recursos, poluição e organismos exóticos (COBLENTZ, 1990). A EEcA, como ocorre com a grande maioria das unidades de conservação, também tem registrada a ocorrência de organismos exóticos em seu interior. Segundo Coblentz (1990), organismos exóticos são aqueles que não são nativos do ecossistema, no qual são introduzidos como resultado da atividade humana. Complementa o autor que tais organismos podem ser plantas, animais ou micróbios e podem ter um ou mais efeitos. Podem, por exemplo, deslocar espécies nativas por meio da competição, extirpar espécies nativas através da transmissão de doenças e reduzir a biodiversidade por meio da degradação do hábitat, aumentando a erosão, e até afetando a ciclagem de nutrientes. Animais domésticos muitas vezes acarretam danos também aos recursos abióticos, provocando compactação e erosão do solo, assoreamento e contaminando corpos d'água (Figuras.8, 9 e 10).

Outra definição de organismos exóticos é apresentada pelo Serviço Nacional de Parques (EUA), em suas definições:

a vida animal nativa é definida como toda espécie animal (incluindo organismos patogênicos) que é resultado do processo natural que ocorre ou ocorreria nas terras designadas como Parques. Quaisquer espécies que tenham sido movidas em direção aos parques, direta ou indiretamente, como resultado da atividade humana, não são consideradas nativas (AGUIRRE; STARKEY, 1994).

Segundo esses autores, as enfermidades da fauna silvestre têm implicações significativas de manejo em diferentes áreas protegidas pelo Serviço Nacional de Parques dos EUA, devido ao aumento das interações entre animais selvagens e domésticos.

Ainda que este seja um problema real no interior do ecossistema natural, animais invasores são, inevitavelmente, um problema cuja origem está nas áreas circundantes da unidade de conservação, que é por onde se desencadeia a invasão. Isto ocorre porque a paisagem ao redor 
da UC é, na maioria das vezes, extremamente perturbada pelos distúrbios produzidos pelas atividades antrópicas, tais como: agricultura, urbanização, rodovias, outros (SMALLWOOD, 1994). De fato, a paisagem ao redor das reservas e de outras áreas naturais deveriam ser gerenciadas de modo que protegessem e promovessem espécies nativas e seu hábitat e que se buscasse a erradicação das exóticas. Argumenta o autor que a erradicação das espécies exóticas tem sido proposta para proteger a integridade das reservas naturais, mas que este pode ser um ataque inócuo aos sintomas, se não houver a cura das causas da suscetibilidade de um local à invasão pelas espécies exóticas.

Dois grandes grupos de animais exóticos invadem ecossistemas naturais: animais domésticos (cães e gatos, principalmente) e animais de criação (bovinos, caprinos, suínos, ovinos). Um terceiro tipo de invasão por animais exóticos em ecossistemas naturais vem sendo registrado com freqüência crescente: são espécies animais silvestres oriundas de outras regiões do país ou do mundo, que se disseminam facilmente em condições de desequilíbrio, geralmente relacionadas com a abundância de alimento e ausência de predadores específicos.

No caso da Estação Ecológica de Assis, têm sido registrados casos de invasão por gado bovino, cães e gatos domésticos e por animais silvestres exógenos, como a lebre européia (Lepus capensis), inicialmente introduzida na Argentina e hoje disseminada por boa parte da América do Sul. Estudos pioneiros com esta espécie invasora indicam a redução populacional de uma espécie nativa, o tapiti (Sylvilagus brasiliensis), concomitantemente ao aumento populacional da lebre européia, sugerindo o deslocamento do tapiti (GRIGERA; RAPOPORT, 1983).

Para contenção da invasão pelo gado bovino, cujo impacto é por herbivoria e danos mecânicos à vegetação natural, além da compactação e erosão do solo, a solução encontra respaldo jurídico no artigo. 936 do Código Civil (BRASIL, 2002a), que prevê: 
Art. 936 - O dono ou detentor do animal ressarcirá o dano por este causado, se não prover culpa da vítima ou força maior.

O instituto jurídico que respalda o dispositivo supracitado é o da responsabilidade civil, referente à sanção civil imposta ao autor dos prejuízos, para ressarcir a vítima dos danos sofridos na esfera patrimonial. O proprietário do animal, no exercício de sua posse e sua guarda, está sujeito a assumir responsabilidades, pois, em geral, se o animal lesar alguém, tem o proprietário o dever legal de cobrir tais prejuízos. São inúmeros os problemas que os animais podem causar para os ecossistemas das unidades de conservação e o impacto ambiental muitas vezes é irreversível, assim como os animais também podem gerar impactos patrimoniais importantes. O conceito de impacto ambiental é definido pela Resolução CONAMA 01/86 (BRASIL, 1986) a qual dispõe:

$$
\begin{aligned}
& \text { Artigo } \mathbf{1}^{\mathbf{0}} \text { - Para efeito desta Resolução, considera-se impacto ambiental } \\
& \text { qualquer alteração das propriedades fisicas, químicas e biológicas do meio } \\
& \text { ambiente, causada por qualquer forma de matéria ou energia resultante das } \\
& \text { atividades humanas que, direta ou indiretamente, afetam: } \\
& \text { I - a saúde, a segurança e o bem-estar da população; } \\
& \text { II - as atividades sociais e econômicas; } \\
& \text { III - a biota; } \\
& \text { IV - as condições estéticas e sanitárias do meio ambiente; } \\
& \text { V - a qualidade dos recursos ambientais. }
\end{aligned}
$$
qualquer alteração das propriedades fisicas, químicas e biológicas do meio ambiente, causada por qualquer forma de matéria ou energia resultante das

Em qualquer caso é o proprietário ou o detentor o responsável pelos danos gerados pelos animais no decorrer de sua guarda. Isto porque, estando os indivíduos sob a vigilância do detentor ou proprietário, os fatos pelos animais provocados devem ser considerados atos indiretos dos que deveriam vigiá-los e dominá-los. Portanto, de grande relevância na vida em sociedade são as relações decorrentes de atos praticados pelos animais enquanto sob a posse de seu detentor. Um descuido ou descaso com as medidas necessárias para a pacífica e harmônica posse destes 
semoventes (denominação jurídica dada aos animais domesticados e explorados economicamente pelo homem) podem trazer conseqüências graves e até mesmo irremediáveis para a unidade de conservação.

Aplica-se também para esse caso o princípio do poluidor-pagador. Tal princípio é regulamentado pelo art. $4^{\circ}$, VII e art. $14, \S 1^{\circ}$ da Lei $n^{\circ} .6 .938 / 81$ (Política Nacional do Meio Ambiente $^{36}$ ). Para Derani (1997), o princípio do poluidor-pagador objetiva à internalização dos custos relativos externos da deterioração ambiental. Isto acarretaria como conseqüência um maior zelo em relação ao potencial poluidor da produção, na busca de uma satisfatória qualidade ambiental. Para a autora, a utilização deste princípio aplica-se ao "sujeito econômico" (produtor, consumidor, transportador), que nesta relação pode gerar um problema ambiental, e deve, portanto, responsabilizar-se com os custos da diminuição ou afastamento do dano.

Afirma Derani (1997, p. 158) que:

Durante o processo produtivo, além do produto a ser comercializado, são produzidas "externalidades negativas". São chamadas externalidades porque, embora resultantes da produção, são recebidas pela coletividade, ao contrário do lucro, que é percebido pelo produtor privado. Daí a expressão "privatização de lucros e socialização de perdas", quando identificadas as externalidades negativas. Com a aplicação do princípio do poluidor-pagador, procura-se corrigir este custo adicionado à sociedade, impondo-se sua internalização. Por isto, este princípio também é conhecido como o princípio da responsabilidade.

Finaliza Derani (1997) que, pelo princípio do poluidor-pagador, cabe ao causador da poluição arcar com os custos correspondentes à redução, eliminação ou neutralização deste dano.

\footnotetext{
${ }^{36}$ Diz a lei: art. $4^{\text {o }}$. A Política Nacional do Meio Ambiente visará: VII - à imposição, ao poluidor e ao predador, da obrigação de recuperar e/ou indenizar os danos causados e, ao usuário, da contribuição pela utilização dos recursos ambientais com fins econômicos. Art. 14. Sem prejuízo das penalidades definidas pela legislação federal, estadual e municipal, o não-cumprimento das medidas necessárias à preservação ou correção dos inconvenientes e danos causados pela degradação da qualidade ambiental sujeitará os transgressores: $\S 1^{\circ}$ Sem obstar a aplicação das penalidades previstas neste artigo, é o poluidor obrigado, independentemente da existência de culpa, a indenizar ou reparar os danos causados ao meio ambiente e a terceiros, afetados por sua atividade. O Ministério Público da União e dos Estados terá legitimidade para propor ação de responsabilidade civil e criminal, por danos causados ao meio ambiente.
} 
A solução passa também pelo manejo da unidade de conservação, com a manutenção das cercas, que, entre propriedades confinantes, é de responsabilidade de ambos, ou seja, neste caso, a unidade de conservação e o proprietário rural. Tal disposição é prevista legalmente no artigo 1.297, $\S 1^{\circ}, \S 2^{\circ}$ e $\S 3^{\circ}$, do Código Civil (BRASIL, 2002a), que dispõe:

Art. 1.297 - O proprietário tem direito a cercar, murar, valar ou tapar de qualquer modo o seu prédio, urbano ou rural, e pode constranger o seu confinante a proceder com ele à demarcação entre os dois prédios, a aviventar rumos apagados e a renovar marcos destruidos ou arruinados, repartindo-se proporcionalmente entre os interessados as respectivas despesas.

$\S \mathbf{1}^{\mathbf{0}}$ - Os intervalos, muros, cercas e os tapumes divisórios, tais como sebes vivas, cercas de arame ou de madeira, valas ou banquetas, presumem-se, até prova em contrário, pertencer a ambos os proprietários confinantes, sendo estes obrigados, de conformidade com os costumes da localidade, a concorrer, em partes iguais, para as despesas de sua construção e conservação.

$\S \mathbf{2}^{\mathbf{0}}$ - As sebes vivas, as árvores, ou plantas quaisquer, que servem de marco divisório, só podem ser cortadas, ou arrancadas, de comum acordo entre proprietários.

$\S \mathbf{3}^{\mathbf{0}}-$ A construção de tapumes especiais para impedir a passagem de animais de pequeno porte, ou para outro fim, pode ser exigida de quem provocou a necessidade deles, pelo proprietário, que não está obrigado a concorrer para as despesas.

Animais domésticos, como cães e gatos, quando invadem áreas naturais, comportam-se como predadores, uma vez que são carnívoros, passando a exercer pressão sobre as populações de animais nativos (CAMPOS, 2004). A primeira dificuldade para eliminar esta ameaça está em identificar os proprietários desses animais. Ocorre que muitos desses animais errantes são abandonados por seus proprietários ou foram gerados em espaço público, não sendo possível a identificação de posse. Destaca-se que o aterro sanitário existente na Zona de Amortecimento da Estação Ecológica de Assis é um atrativo para a permanência desses animais no local, servindo como fonte de sua subsistência e potencializando a ameaça oferecida pelos animais domésticos.

Para os animais errantes, cabe a intervenção da Prefeitura Municipal, por meio do Departamento de Controle e Zoonoses, realizar o seu manejo e ao mesmo órgão caberá zelar pela 
saúde pública da população, mantendo, sobre seu território, animais sadios e devidamente imunizados. Nesse caso, a unidade de conservação deverá acionar a Prefeitura para que realize a captura desses animais e encaminhamento ao canil municipal.

O Plano Diretor de Assis, no artigo. 20, inciso VIII (PREFEITURA MUNICIPAL DE ASSIS, 2006), dispõe sobre a política de saneamento integrado e a elaboração e instituição de um Plano de Controle de Zoonoses em área municipal. Para que o Plano alcance a eficácia almejada, deverá estabelecer sanções às pessoas que não exercerem a posse responsável dos animais domésticos. Além disso, o Plano deverá englobar alguns itens para que atenda à sua finalidade, tais como: i) termo de responsabilidade, contendo o registro do animal, assinado pelo proprietário, que deverá ser lavrado no órgão público municipal competente; ii) fiscalização de criadouros (canis e gatis), impondo aos criadores a obrigatoriedade de realizarem a venda dos animais somente após a realização do seu registro; iii) campanhas sócio-educativas, embasadas na reversão do processo de abandono dos animais que chegam às unidades de conservação; iv) o Plano deverá estar disposto em lei municipal e deverá ser designada a autoridade competente para a efetiva fiscalização de seu cumprimento.

O manejo dos animais domésticos errantes muitas vezes não é resolvido pela falta de vontade política e pelo motivo de esse ser considerado pelas autoridades como um "problema de escala menor". Existem municípios paulistas que criaram legislação sobre a posse responsável, tais como Jundiaí, Limeira e São Paulo, entre outros.

Quanto aos animais domésticos que possuem donos identificados, prevalece, também, o artigo. 936, do Código Civil (BRASIL, 2002a), apoiado pelo instituto jurídico da responsabilidade civil anteriormente descrito.

Para os animais silvestres invasores, como a lebre européia (Lepus capensis), que acarreta prejuízos ao ecossistema por competir com as populações de animais nativos que ocupam o 
mesmo nicho, há conflitos jurídicos importantes e, também, dúvidas decorrentes da interpretação dos termos da lei.

Por um lado, o SNUC (PINTO; WINDT; SIQUEIRA, 2001), em seu art. 31, diz que:

É proibida a introdução nas unidades de conservação de espécies não autóctones.

No art. $9^{\circ}, \S 4^{0}$, II, está escrito ainda que:

Na Estação Ecológica só podem ser permitidas alterações dos ecossistemas no caso de: manejo de espécies com o fim de preservar a diversidade biológica;

A partir da lei federal, portanto, deduz-se que são permitidas ações de manejo voltadas à eliminação das espécies animais exóticas, uma vez que oferecem ameaça ao equilíbrio do ecossistema natural.

Por outro lado, a Constituição paulista (SÃO PAULO, 1989) prevê que:

Art. 204 - Fica proibida a caça, sob qualquer pretexto, em todo o Estado.

Nestes dois dispositivos jurídicos foi identificado um conflito legal, envolvendo normas de diferentes níveis hierárquicos. Retoma-se, neste caso, conceito expresso constitucionalmente sobre competência, no qual a Constituição Federal confere competência concorrente para a União, Estados e Distrito Federal legislarem sobre a caça (art.24, inciso VI - BRASIL, 1988).

Nestes casos, o conflito deverá ser dirimido pela via judiciária. A questão, até o presente momento, é objeto de uma Ação Direta de Inconstitucionalidade (ADI 350-0/600), que está aguardando para ser julgada pelo Supremo Tribunal Federal - STF.

A razão da ADI é que o Estado de São Paulo, fundamentando-se em uma garantia constitucional, estabeleceu a proteção das espécies exóticas e proibiu a caça sob qualquer fundamento no estado. 
Por outro lado, poder-se-ia interpretar o disposto na Constituição Estadual de outra forma. O abate de animais exóticos invasores, mediante estudo técnico científico e realizado com técnicas internacionalmente reconhecidas, não deveria ser interpretado como caça ${ }^{37}$ e, assim, o conflito jurídico deixaria de existir.

Para Sodero (1977, p. 350), caçar tem sentido amplo, constituindo-se:

no ato de caçar, de perseguir animais silvestres, portanto não domesticados, para os apanhar vivos, ou mortos (...). Na terminologia jurídica entende-se, pela expressão, a perseguição e a procura, pelo homem, de animais silvestres (bravios ou que vivem em liberdade natural), com a intenção de se apropriar deles, desde que não tenham nenhum dono.

Esse conceito descrito por Sodero encontra amparo legal no art. $7^{\circ}$, caput da Lei $n^{\circ}$. 5.197/67 (que dispõe sobre a proteção à fauna - BRASIL, 1967), estabelecendo que:

Art. $7^{\circ}$ - A utilização, perseguição, destruição, caça ou apanha de espécimes da fauna silvestre, quando consentidas na forma desta Lei, serão considerados atos de caça (Grifo nosso).

O dispositivo supracitado refere-se aos atos de caça e mencionava unicamente espécimes da fauna silvestre, não incluindo nesse rol as exóticas. As condutas descritas no art. $7^{\circ}$ evoluíram e foram posteriormente tratadas pela Lei dos Crimes Ambientais (Lei nº. 9.605/98 - BRASIL, 1998), a qual estabeleceu entre os crimes:

Art. 29 - Matar, perseguir, caçar, apanhar, utilizar espécimes da fauna silvestre, nativos ou em rota migratória, sem a devida permissão, licença ou autorização da autoridade competente, ou em desacordo com a obtida.

O art. 29 da Lei $n^{\circ} .9 .605 / 98$ (BRASIL, 1998) também não fez referência às espécies exóticas. Porém, no mesmo instituto existe um dispositivo que pode fundamentar o abate das espécies invasoras, que prevê:

Art. 37 - Não é crime o abate de animal, quando realizado:

\footnotetext{
${ }^{37}$ A acepção da palavra caça pode ser compreendida como: busca, perseguição e acossamento segundo FERREIRA, A.B. H (1986). Novo Dicionário da Língua Portuguesa. Editora Nova Fronteira
} 
IV - por ser nocivo o animal, desde que assim caracterizado pelo órgão competente.

O abate de espécies invasoras para o reequilíbrio do ecossistema, no interior das UCs, desde que autorizado pelo órgão competente (IBAMA), não pode, perante esta interpretação, ser enquadrado como crime ambiental e deveria ser previsto nas recomendações do Plano de Manejo.

Para Nassaro (2004), o equilíbrio ambiental é a chave do entendimento de que existe inconstitucionalidade no artigo. 204 da Constituição Estadual, quando interpretado sob o ponto de vista de vedação total à prática das modalidades de caça porque ele veda, em determinadas circunstâncias, a busca do equilíbrio ambiental, mediante a utilização de técnicas de pesquisa, manejo e controle de espécies.

Devido à legislação não ser clara, no momento, o gestor não encontra, nas leis, respaldo para a tomada de decisões relativas à eliminação da ameaça oferecida pelos animais exóticos que invadem as unidades de conservação a partir das propriedades vizinhas.

\subsubsection{Depósito de entulho}

A deposição de entulho é, geralmente, um problema associado com a proximidade da zona urbana (Figuras.11 e 12). Estima-se que os resíduos da construção civil e demolição representem de 41 a 70\% do total dos resíduos sólidos gerados em áreas urbanas (PINTO, 1999). Os melhores exemplos de políticas públicas vigentes em diversos países originaram-se de uma pesquisa realizada em 1999 pelo WPPPC - Working Parting Pollution Prevention and Control of the Environment Policy Committee of the Organization for Economic Cooperation and Development - OECD. A Holanda foi um dos países estudados e uma das estratégias adotadas pelos holandeses foi a limitação de componentes perigosos em materiais de construção. Em 1999, 
aquele país aprovou um decreto que estabeleceu padrões para a quantidade máxima de substâncias perigosas contidas em materiais de construção, que poderiam impactar o solo e a água superficial, por lixiviação, no uso e quando da sua reciclagem (MURAKAMI et al., 2002), que seriam os possíveis impactos ambientais decorrentes da deposição inadequada de resíduos da construção civil e de demolição.

A ameaça representada pelo depósito de entulho existente no interior da zona tampão da Estação Ecológica de Assis relaciona-se à sua proximidade das nascentes de um córrego (Água do Pavãozinho) e não se pode dizer que afeta diretamente os recursos naturais do interior da área protegida, mas, sem dúvida, compromete a paisagem e a qualidade ambiental do entorno.

O município não possui local apropriado para o descarte dos resíduos produzidos pela construção civil, os quais são popularmente designados como "bota-fora". No local não são descartados somente resíduos da construção civil, sendo também depositados móveis velhos, aparelhos eletrodomésticos ultrapassados, entre muitos outros objetos. Este problema é muito comum nos municípios brasileiros e a sua disposição inadequada colabora para a degradação da qualidade ambiental.

Visando coibir e reverter este quadro, o Conselho Nacional do Meio Ambiente CONAMA publicou a Resolução nº. 307/02 (BRASIL, 2002c) ${ }^{38}$. Antes desta Resolução o Brasil não tinha políticas públicas para os resíduos gerados pelo setor da construção civil. Neste sentido, a Resolução passou a ser o principal instrumento legal em âmbito federal sobre o assunto (SCHNEIDER; PHILIPPI Jr., 2004).

O embasamento legal desta Resolução encontra-se no Estatuto da Cidade, que prevê a obrigatoriedade da política urbana estar em total consonância com o desenvolvimento da função

\footnotetext{
${ }^{38} \mathrm{O}$ teor da Resolução encontra-se no anexo.
} 
social da cidade e da propriedade urbana. Outra inovação trazida pela Resolução refere-se à responsabilização dos geradores de resíduos da construção civil nas mais diversas atividades do setor. Além disso, a Resolução também estabelece que os resíduos não poderão ser dispostos em aterros de resíduos domiciliares, em áreas de "bota-fora", em encostas, corpos d'água, lotes vagos e áreas protegidas pela lei.

A Resolução CONAMA também prevê a obrigatoriedade dos municípios e do Distrito Federal elaborarem o Plano Integrado de Gerenciamento de Resíduos da Construção Civil e as diretrizes a serem seguidas em conformidade com os artigos $5^{\circ}$ e $6^{\circ}$. Visando o cumprimento dessa norma, o Plano Diretor de Assis normatizou a questão em seu art.23, inciso IV e $\S 2^{\circ}$ (PREFEITURA MUNICIPAL DE ASSIS, 2006).

A ameaça aos recursos naturais decorrente da deposição de entulho pode, portanto, ser solucionada apenas mediante a aplicação dos instrumentos jurídicos existentes, dependendo apenas da fiscalização pelos órgãos competentes. Aos gestores da unidade cabe apenas acionálos.

\subsection{CONSIDERAÇÕES FINAIS}

Diante da análise da legislação vigente aplicada ao estudo de caso da Estação Ecológica de Assis, considera-se que os gestores da unidade de conservação dispõem de ferramentas de natureza distinta para lidar com os conflitos relacionados com a Zona de Entorno e de Amortecimento, que nem sempre incluem instrumentos jurídicos.

Conflitos de uso, tais como: expansão urbana, aterro sanitário e depósito de entulho, dependem prioritariamente de legislação municipal, disposta em normas de planejamento e ordenamento territorial inseridos no Plano Diretor, uma vez que as leis federais normatizando 
atividades da Zona de Entorno e de Amortecimento são insuficientes para solucionar esses problemas.

Há conflitos de uso, como é o caso da invasão da área protegida por animais domésticos, cuja solução, hoje, transcende a competência do gestor, uma vez que há conflitos jurídicos pendentes sobre o assunto.

Importante ferramenta de apoio à gestão não tem sido utilizada no caso da Estação Ecológica de Assis, que é a indicação, pelo órgão gestor juntamente com os órgãos licenciadores, de quais são as atividades que podem colocar em risco os ecossistemas naturais da unidade de conservação. Podem ser então incluídas, entre atividades que exigem licenciamento, por exemplo, mudanças indesejáveis de uso da terra, que hoje não encontram respaldo nas leis vigentes.

Para atividades na Zona de Entorno e de Amortecimento sobre as quais a lei é omissa o gestor depende de ações outras que não as de natureza jurídica, especialmente de integração com as comunidades vizinhas através de conscientização ambiental e fomento a formas de uso da terra de baixo impacto. 


\section{CAPÍTULO 2 A EFICÁCIA DO LICENCIAMENTO AMBIENTAL NA CONTENÇÃO DE ATIVIDADES IMPACTANTES NA ZONA DE ENTORNO DA ESTAÇÃO ECOLÓGICA DE ASSIS, SP}

\subsection{INTRODUÇÃO}

As pesquisas desenvolvidas na área acadêmica no tocante aos espaços territorialmente protegidos versam, em sua maioria, sobre a função ambiental que esses espaços desempenham para a conservação da diversidade biológica.

Porém, a conservação esbarra, via de regra, em obstáculos oriundos do arcabouço jurídico, não só concernente às questões ambientais, mas também a leis que regem o direito de propriedade, as relações de vizinhança e a saúde pública, entre outros institutos jurídicos (detalhadamente apresentados na Introdução desta dissertação). Desse modo, faz-se necessária a abordagem das questões correlatas à conservação dos recursos naturais sob o ponto de vista legal do processo de licenciamento, visando, sobretudo, à solução de conflitos porventura existentes, que possam colocar em risco os recursos naturais contidos nas áreas protegidas.

O conflito fundamental vislumbrado, no caso da Zona de Entorno de unidades de conservação, é como conciliar o desenvolvimento da atividade econômica e a conservação dos recursos naturais (DERANI, 1997). Em prol dessa conciliação, os gestores das unidades de conservação possuem uma importante ferramenta, que é o poder de veto sobre atividades potencialmente impactantes em áreas que estejam situadas na Zona de Entorno, estabelecida pela Resolução CONAMA nº. 13/90 (BRASIL, 1990b).

O texto da Resolução, em seu Art. $1^{\circ}$, diz que: o órgão responsável por cada unidade de 
conservação, juntamente com os órgãos licenciadores e de meio ambiente, definirá as atividades que possam afetar a biota da unidade de conservação. O Art. $2^{\circ}$ estabelece que a Resolução se aplica a um raio de $10 \mathrm{~km}$ das unidades e que o licenciamento...só será concedido mediante autorização do órgão responsável pela administração da unidade de conservação.

Esse dispositivo jurídico foi, posteriormente, reforçado pela Lei $\mathrm{n}^{\circ}$. 9.985/00 (PINTO; WINDT; SIQUEIRA, 2001), que instituiu o Sistema Nacional de Unidades de Conservação SNUC, em que fica estabelecida a necessidade de delimitação da Zona de Amortecimento.

O conceito de Zona de Amortecimento adotado pelo SNUC mantém a proposta original feita pela United Nations Educational, Scientific and Cultural Organization (UNESCO, 1968), por meio do "Programa Homem e Biosfera". Este programa concebeu a primeira proposta sobre a Zona de Amortecimento, que era definida como: "geralmente são terras vizinhas aos parques e reservas onde as atividades humanas se restringem àquelas que manterão a proteção ecológica da área protegida enquanto promovem benefícios às comunidades locais" (NEUMANN, 1997, tradução nossa).

Diz a Lei $n^{\text {o. }}$ 9.985/00 (PINTO; WINDT; SIQUEIRA, 2001) que: a Zona de Amortecimento corresponde ao entorno de uma unidade de conservação, onde as atividades humanas estão sujeitas a normas e restrições específicas, com o propósito de minimizar os impactos negativos sobre a unidade.

A Zona de Amortecimento de uma unidade de conservação é estabelecida no Plano de Manejo, que, pelo texto da Lei, é o documento técnico mediante o qual, com fundamento nos objetivos gerais de uma unidade de conservação, se estabelece o seu zoneamento e as normas que devem presidir o uso da área e o manejo dos recursos naturais [...].

No artigo. 27 da mesma lei fica estabelecido que as unidades de conservação devem dispor de um Plano de Manejo e, no $\S 1^{\circ}$, que: o Plano de Manejo deve abranger a área da 
unidade de conservação, sua Zona de Amortecimento e os corredores ecológicos, incluindo medidas com o fim de promover sua integração à vida econômica e social das comunidades vizinhas (Grifo nosso).

Em síntese, prevê a lei que toda unidade de conservação (exceto a Área de Proteção Ambiental e a Reserva Particular do Patrimônio Natural - art. 25, caput, SNUC) deve ter uma Zona de Amortecimento definida pelo Plano de Manejo, na qual não devem ser realizadas atividades ou instalados empreendimentos que coloquem em risco a integridade dos recursos naturais.

O Decreto $\mathrm{n}^{\mathrm{o}} .4 .340$, de 22 de agosto de 2002 (BRASIL, 2002b), que regulamenta a Lei n. 9.985/00 (PINTO; WINDT; SIQUEIRA, 2001) estabelece, no inciso VIII do art. 20, que compete ao conselho da unidade de conservação manifestar-se sobre obra ou atividade potencialmente causadora de impacto na unidade de conservação, em sua Zona de Amortecimento, mosaicos ou corredores ecológicos.

No Estado de São Paulo, o Departamento Estadual de Proteção dos Recursos Naturais — DEPRN, é o órgão ambiental, subordinado à Secretaria do Meio Ambiente do Estado de São Paulo, responsável pelo licenciamento das atividades e obras que impliquem na supressão da vegetação nativa, corte de árvores nativas, intervenção em Área de Preservação Permanente (APP) e manejo da fauna silvestre, todas essas atividades potencialmente impactantes aos ecossistemas naturais. A legislação que regulamenta a APP é o Código Florestal (arts. $2^{\circ}$ e $3^{\circ}$ da Lei $\mathrm{n}^{\circ} .4771$, de 15 de setembro de 1965 - BRASIL, 1965).

De acordo com o $\operatorname{art} .1^{\circ}, \S 2^{\circ}$, II do Código Florestal, a finalidade da APP é de preservar os recursos hídricos, a paisagem, a estabilidade geológica, a biodiversidade, o fluxo gênico de fauna e flora, proteger o solo e assegurar o bem-estar das populações humanas. O DEPRN representa um dos elos da política conservacionista, pois, ao exercer o poder de polícia, detém os 
instrumentos de comando e controle, ou seja, a concessão ou não da licença ambiental de empreendimentos situados ou próximos à Zona de Entorno de unidades de conservação. Além de fiscalizar o cumprimento da legislação ambiental, cabe a ele também atribuir penalidades aos que desrespeitarem as normas de conservação e de preservação dos recursos naturais.

$\mathrm{Na}$ aplicação das leis, depreende-se que os processos de licenciamento que tratem de propriedades inseridas na Zona de Entorno das unidades de conservação devem ser encaminhados, pelo DEPRN, à instituição gestora das unidades de conservação, no caso da presente pesquisa, o Instituto Florestal (IF).

O objetivo específico deste capítulo foi avaliar a eficácia das leis que estabelecem esse procedimento em, efetivamente, impedir que sejam instaladas obras ou atividades impactantes na Zona de Entorno e efetuar um diagnóstico das principais atividades que têm sido objeto de licenciamento ambiental ao redor da Estação Ecológica pertencente ao Instituto Florestal, localizada no município de Assis.

\subsection{MATERIAL E MÉTODOS}

\subsection{1 Área de estudo}

A Estação Ecológica de Assis - EEcA encontra-se minuciosamente descrita no Cap.1 desta dissertação. No entanto, cabe salientar que a única norma incidente sobre a Zona de Entorno da Estação Ecológica de Assis, enquanto seu Plano de Manejo não for aprovado pelo CONSEMA, é a Resolução CONAMA nº 13/90 (BRASIL, 1990b) e foi com base neste texto que se delimitou o universo amostral do presente estudo, ou seja, o raio de dez quilômetros a partir dos limites da unidade. Além disso, entre 1990 e 2005, antes da aprovação do Plano de Manejo da Floresta Estadual de Assis, a norma que regia o procedimento do DEPRN, em relação 
a ambas as unidades, era a Resolução CONAMA.

Conforme discutido na Introdução do presente estudo, considera-se que, mesmo nos casos em que exista Plano de Manejo aprovado pelo CONSEMA, a Resolução CONAMA 13/90 (BRASIL, 1990b) continua vigente e é o instituto jurídico que estabelece normas para o licenciamento ambiental ao redor de estações ecológicas.

\subsubsection{Levantamento de dados}

A partir do mapa com a localização da Estação Ecológica de Assis, foi delimitada a área dentro de um raio de $10 \mathrm{~km}$ a partir do limite da unidade (Resolução CONAMA no . 13/90 BRASIL, 1990b), englobando, além do município de Assis (cerca de 95\% da Zona de Entorno da EEcA), também parte dos municípios de Platina, Echaporã e Paraguaçu Paulista.

Foram levantados os processos de licenciamento que passaram pelo Departamento Estadual de Proteção dos Recursos Naturais (DEPRN), desde a publicação da Resolução CONAMA nº. 13/90 - BRASIL, 1990b (28 de dezembro de 1990) até a época da realização da pesquisa de (07 a 09 de agosto de 2006), que tratassem de áreas no interior da Zona de Entorno da unidade de conservação em estudo.

Foram analisados, no total, 3.721 processos, dos quais somente $155(4 \%)$ tratavam de pedidos de licenciamento de obras inseridas dentro da Zona de Entorno da EEcA.

Para cada um destes 155 processos foram registradas as seguintes informações:

1. Identificação da parte interessada (órgão público ou particular);

2. $\quad$ Em qual (is) município(s) se situava(m) o(s) empreendimento(s);

3. Se o empreendimento estaria localizado em área urbana ou rural;

4. Qual foi o assunto abordado e a natureza do licenciamento; 
5. Se o Instituto Florestal (IF) foi ouvido e, nestes casos, se o parecer era favorável e se havia recomendações;

6. Em quais situações os processos foram remetidos para o IF e se as recomendações do IF foram seguidas pelo DEPRN;

7. Qual a decisão final do DEPRN.

As informações obtidas na análise dos 155 processos foram tabuladas e submetidas a análises quantitativas segundo os itens em avaliação. Com base nesses dados, foi efetuado um diagnóstico das ameaças mais freqüentes à unidade em estudo, com base nos pedidos de licenciamento, e análise da eficácia das leis vigentes em impedir que sejam aprovadas obras ou atividades à revelia do órgão gestor.

\subsection{RESULTADOS E DISCUSSÃO}

A análise dos interessados nos processos de licenciamento (Fig.13) mostrou que em 26\% dos processos os interessados eram órgãos públicos e $74 \%$ eram oriundos da iniciativa privada, sendo que, destes, $15 \%$ eram pessoas jurídicas. A maioria dos processos, portanto, tratou de pedidos de licenciamento desencadeados por pessoas físicas, de modo geral proprietários rurais. 


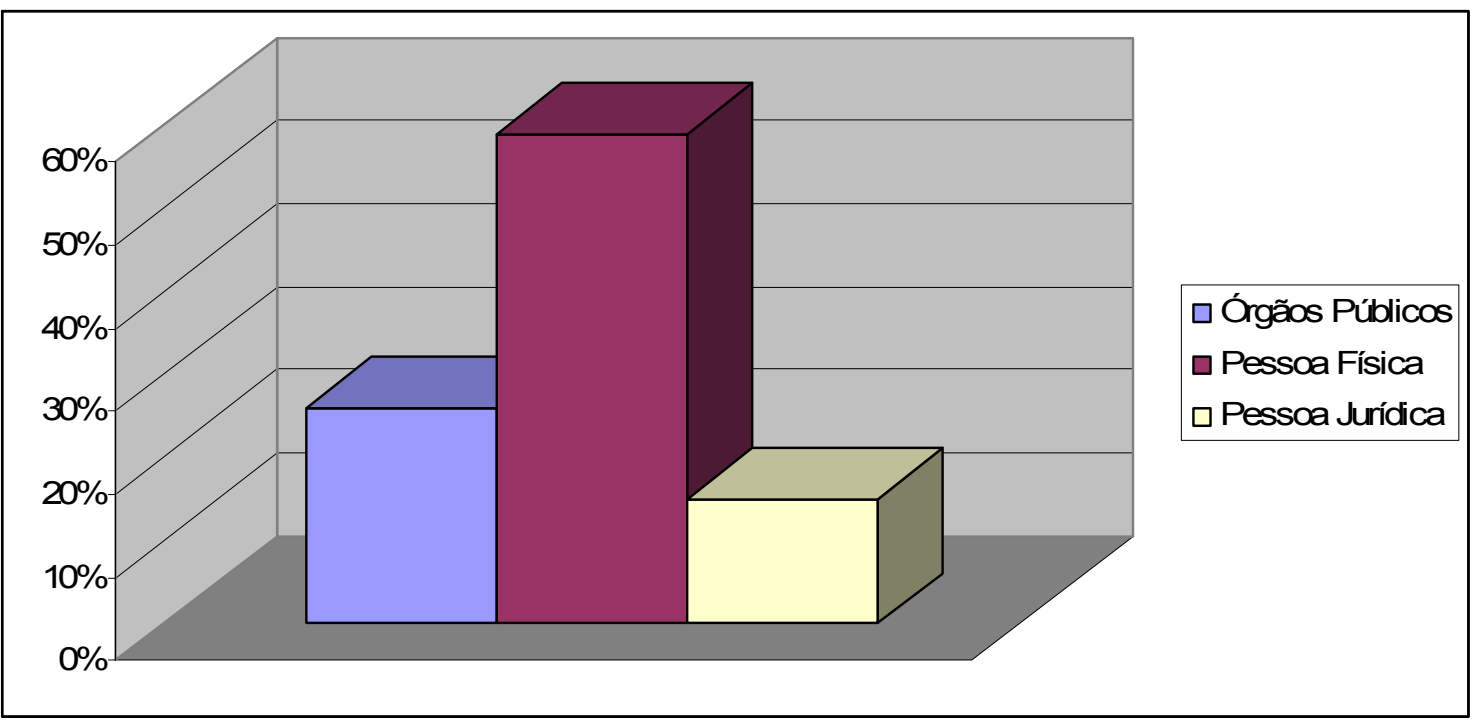

Figura 13. Partes interessadas nos pedidos de licenciamento ambiental na Zona de Entorno da Estação Ecológica de Assis, SP

A distribuição dos processos por município (Fig.14) mostra que houve pedidos de licenciamento de obras em municípios, além de Assis, mas há processos que tratam de todos os municípios pertencentes ao Consórcio do Médio Paranapanema. Em Assis, município em que se encontra a quase totalidade da Zona de Entorno da unidade de conservação, concentra-se a maioria absoluta dos pedidos de licenciamento. 


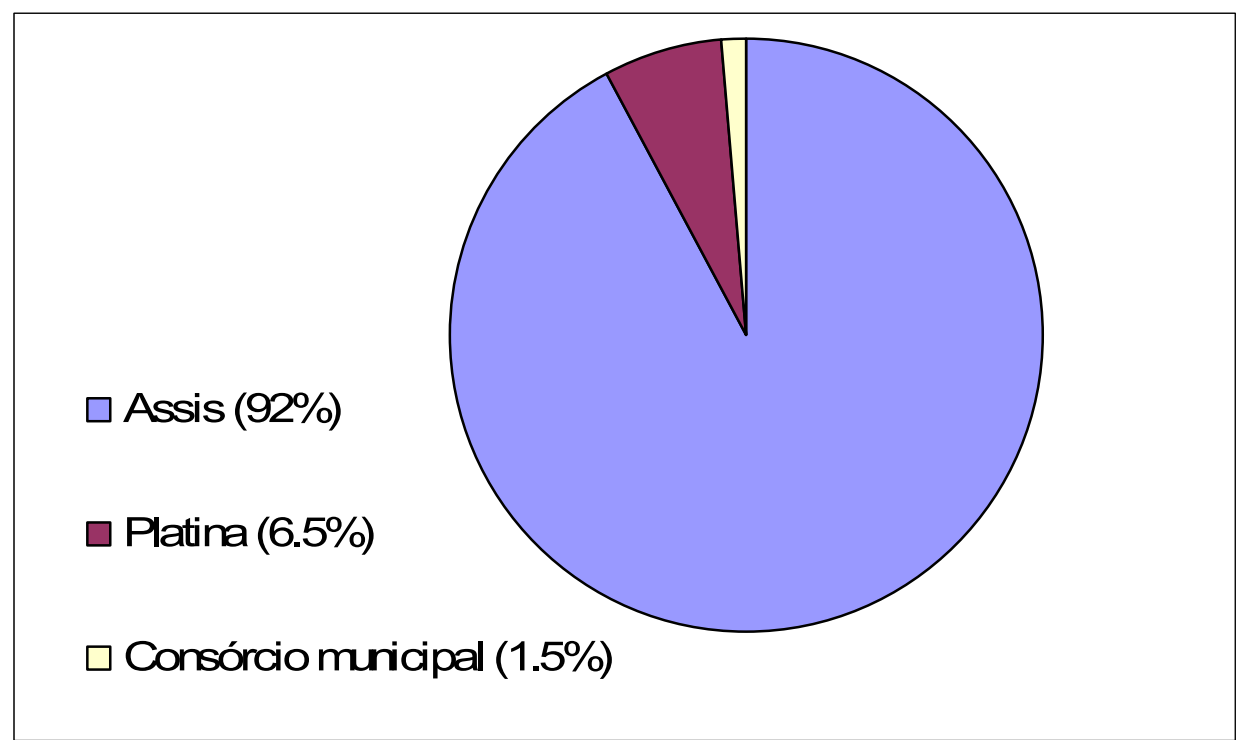

Figura14. Distribuição dos processos de licenciamento ambiental na Zona de Entorno da Estação Ecológica de Assis, SP, por município onde se situam as obras

Quanto à distribuição dos processos entre área urbana e rural, dos 155 processos analisados, 79\% tratavam de área rural.

Os assuntos mais freqüentes nos pedidos de licenciamento (Fig.15) foram o corte de árvores isoladas e a intervenção em Área de Preservação Permanente (APP). A intervenção em APP geralmente é decorrente da necessidade de compensar, por meio do plantio de restauração da mata ciliar, as perdas decorrentes do corte de árvores isoladas. 


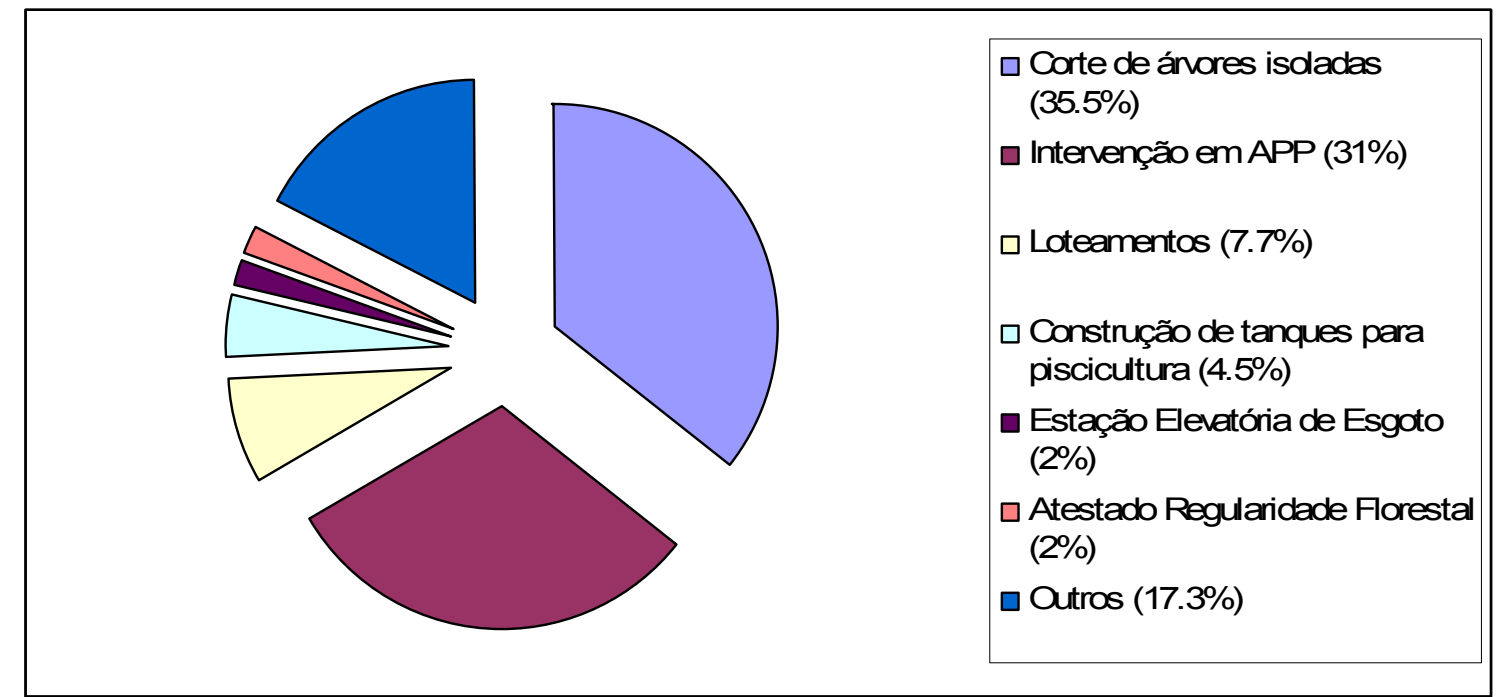

Figura 15. Temas mais freqüentes nos pedidos de licenciamento ambiental na Zona de Entorno da Estação Ecológica de Assis, SP

Esses pedidos refletem a mudança de uso do solo na região e esta tem sido a principal fonte de ameaça aos recursos naturais da Estação Ecológica de Assis. De uma matriz em que predominavam pastagens, constata-se uma tendência relativamente recente de conversão do uso da terra para agricultura, especialmente cana-de-açúcar. A substituição da pastagem pela cana-deaçúcar ou pela soja, no caso do presente estudo, implica o corte de árvores isoladas, que dificultam a mecanização.

A tendência de substituição das pastagens pela agricultura tem sido observada em toda a região de domínio do cerrado, processo este documentado por diversos pesquisadores (ALHO; MARTINS, 1995; RATTER; RIBEIRO; BRIDGEWATER, 1997; KLINK; MOREIRA, 2002; RATTER; BRIDGEWATER; RIBEIRO, 2006).

Até cerca de 35 anos atrás, segundo Ratter, Bridgewater e Ribeiro (2006), a pecuária extensiva era praticamente a única atividade agropecuária no cerrado. Parte da biodiversidade era mantida, seja nas árvores isoladas, seja na insistente rebrota das plantas do cerrado em meio às pastagens (DURIGAN, 2003), constatada mesmo após incêndios sucessivos (FIEDLER et al., 
2004).

O manejo sustentável da vegetação (experimentado por OLIVEIRA et al., 2002), conciliado com a pecuária extensiva, poderia proporcionar a ocupação sustentável e de baixo impacto em toda a região de domínio do Cerrado, mas nenhuma dessas alternativas tem proporcionado lucratividade comparável à agricultura.

O crescimento da agricultura sobre as áreas de cerrado é resultante de uma combinação de fatores que inclui, segundo Klink e Moreira (2002), investimentos públicos em infra-estrutura, avanços científicos e tecnológicos que tornaram as terras fracas do cerrado potencialmente cultiváveis e a implementação de políticas de desenvolvimento regional. Segundo esses autores, o cerrado produzia no ano de 2002 , respectivamente $40 \%$ da soja e $22 \%$ do milho do país.

Sobre os cerrados de São Paulo, Kronka et al. (2005) constataram que a cana-de-açúcar tem ocupado a maior parte das áreas desmatadas na última década, impulsionada pelo aumento da demanda de biocombustíveis no mercado mundial.

De modo geral, os processos de licenciamento ao redor da Estação Ecológica de Assis não tratam de obras ou atividades de alto impacto, tais como indústrias poluentes ou desmatamento em larga escala. Porém, o impacto quase invisível resultante da conversão das pastagens para agricultura pode agravar os problemas decorrentes do isolamento e levar à redução de hábitat para muitas espécies animais que utilizavam as pastagens na Zona de Entorno como espaço vital.

Apesar de obrigatória por lei, a submissão dos autos do licenciamento aos gestores do Instituto Florestal (IF) não foi obedecida em $92 \%$ dos processos. Dos doze processos que foram remetidos ao IF, 75\% receberam parecer favorável sem restrições (nove), tratando sobre os seguintes assuntos: corte de árvores isoladas dentro da Zona de Entorno (sete), implantação de unidade de conservação em área urbana (um) e autorização para desmatamento (um). Nos processos que tratavam de corte de árvores isoladas e que exigiriam plantio, o IF eventualmente 
opinou sobre as espécies a serem utilizadas nos plantios.

Nos três processos restantes o parecer foi favorável ao solicitado, com condicionantes. Nesses autos, os pedidos de licenciamento abordavam os seguintes assuntos: um processo tratava de corte de árvores isoladas, outro sobre o licenciamento para a duplicação do aterro sanitário (o excedente da usina de lixo do município é depositado neste aterro) e o terceiro sobre limpeza de açude.

Entre os autos desses processos em que o gestor da unidade colocou restrições, o parecer final da instituição gestora foi acatado em todos os pedidos de licenciamento. Porém, o diagnóstico final sobre a análise dos processos mostra que, na maioria dos pedidos de licenciamento ambiental na Zona de Entorno da ÈEcA, o órgão gestor não tem sido ouvido, ou seja, a legislação não tem sido suficiente para impedir que seja concedido o licenciamento das obras nessas áreas.

Duas questões se colocam mediante esta análise: 1) por que os processos não têm sido encaminhados ao órgão gestor? E 2) caso venham a ser encaminhados todos os processos, a instituição gestora (Instituto Florestal) tem estrutura para analisar detalhadamente cada caso e emitir parecer circunstanciado?

Na tentativa de responder à primeira questão, verifica-se que a Resolução CONAMA n ${ }^{\circ}$. 13/90 não estabelece claramente, no texto, quais são as "atividades potencialmente impactantes", devendo esta decisão ser tomada pelo órgão gestor, juntamente com os órgãos licenciadores e de meio ambiente. Uma vez que o Plano de Manejo da unidade não está concluído e que o Plano de Manejo da Floresta Estadual de Assis não indica quais seriam as atividades que deveriam ser objeto de licenciamento, há uma omissão importante a ser resolvida.

$\mathrm{Na}$ tentativa de estabelecer normas que pudessem ser aplicadas a todas as unidades de conservação estaduais, foi criada, em 1997, uma Comissão Técnica com representantes do IF e de 
órgãos de licenciamento da Secretaria de Meio Ambiente (SMA), com objetivo de estabelecer parâmetros para aplicação da Resolução CONAMA nº. 13/90 (BRASIL, 1990b) no Estado de São Paulo, cujos trabalhos resultaram na minuta da Resolução SMA nº. 26/97. Havia, na ocasião, apoio da Assessoria Técnica da Divisão de Reservas e Parques Estaduais do Instituto Florestal (DRPE/IF) às equipes das unidades de conservação, buscando a uniformização de critérios nas manifestações em processos de licenciamento ambiental (OLIVA; COSTA NETO, 2004). Segundo os autores, porém, tal Resolução não foi publicada, mas constituiu referencial para manifestações em processos de licenciamento ambiental de empreendimentos situados no entorno das unidades de conservação no Estado de São Paulo.

A segunda questão não tem como ser respondida para a instituição como um todo. Localmente (na Seção de Assis), o Instituto Florestal conta com um corpo técnico diversificado, capaz de analisar assuntos diversos. Para outras unidades isto pode não ser viável.

Outra proposta seria a criação de um conselho consultivo e deliberativo de caráter multidisciplinar, que poderia solucionar o problema, pois uma vez oficializado, o conselho poderá contribuir na análise dos pedidos de licenciamento.

A eficácia dos instrumentos jurídicos analisados dependerá, essencialmente, de providências que passam pelo estabelecimento de critérios e normas claros para identificar em quais processos a instituição gestora das unidades deve ser ouvida. Pelo texto da lei, a indicação clara dessas atividades deverá constar da versão atualizada do Plano de Manejo da Estação Ecológica de Assis, sob pena de, na falta dessa indicação, o órgão gestor continuar não sendo ouvido nos processos de licenciamento ambiental. Fica evidente, também, a necessidade de maior diálogo entre as instituições.

Além da expansão agrícola, há outras fontes potenciais de impacto aos recursos naturais das unidades de conservação que não tramitam no DEPRN, tais como: a expansão urbana, a 
permanência de animais exóticos e domésticos no entorno ou no interior das unidades, depósito de entulho, rodovia e condomínios para fins residenciais em área rural. Não há, nos autos de processos que tramitaram pelo Instituto Florestal no período de estudo, nenhum processo de licenciamento oriundo de outro órgão licenciador que não o DEPRN. As leis que tratam do licenciamento em Zona de Entorno, no entanto, deveriam aplicar-se a todos os órgãos licenciadores, ou seja, a Resolução CONAMA 13/90 (BRASIL, 1990) vem sendo desconsiderada na maioria dos casos.

Os resultados da análise dos processos de licenciamento pelo presente estudo corroboram a constatação de Oliva (2003) de que, apesar dos avanços que a legislação proporcionou no sentido de mitigar efeitos de borda e manter conectividade entre áreas naturais, isso não tem resultado em ações práticas de delimitação, gestão e manejo da zona tampão. Segundo a autora, três fatores principais têm dificultado essas ações: falta de roteiros para a definição da zona tampão; a peculiaridade que caracteriza a zona tampão de cada unidade, que dificulta a padronização, e a ausência de diretrizes para os gestores, que tendem a tomar decisões subjetivas.

A esses obstáculos mencionados por Oliva (2003), podem ser acrescentados outros oriundos do campo jurídico, tais como: desconhecimento das leis por parte dos elaboradores de Plano de Manejo, desconhecimento do disposto nos Planos de Manejo pelos aplicadores das leis, incompatibilidade entre diferentes normas e desconhecimento da existência de uma zona tampão, reconhecida por lei, pelos proprietários de terras no entorno das áreas protegidas.

Não existe, também, uma prática de "pensar" e estabelecer regras para o entorno das unidades, o que poderá ser alcançado a partir do aperfeiçoamento contínuo dos Planos de Manejo, em diversas fases, consolidando políticas de amortecimento de impactos sobre os ecossistemas naturais, integradas às políticas de planejamento regional, implantadas por 
diferentes órgãos governamentais (OLIVA; COSTA NETO, 2004).

No caso da Estação Ecológica de Assis, verificou-se que importante ferramenta de apoio à gestão não tem sido utilizada, que é a indicação, pelo órgão gestor, juntamente com os órgãos licenciadores, de quais são as atividades que podem colocar em risco os ecossistemas naturais da unidade de conservação. Podem ser então incluídas, entre atividades que exigem licenciamento, por exemplo, aquelas decorrentes de mudanças indesejáveis de uso da terra, que hoje não encontram respaldo nas leis vigentes.

Para atividades na Zona de Entorno e de Amortecimento sobre as quais a lei é omissa o gestor depende de ações outras que não as de natureza jurídica, especialmente de integração com as comunidades vizinhas através de conscientização ambiental e fomento a formas de uso da terra de baixo impacto.

Do ponto de vista da eficácia das leis em conter impactos, constatou-se que as leis não têm sido rigorosamente obedecidas, no que diz respeito à obrigatoriedade de que seja ouvido o órgão gestor das unidades em processos que tratem de atividades potencialmente impactantes. Nos raros casos em que o gestor foi ouvido, seu parecer foi suficiente para impedir a aprovação do pedido de licenciamento.

Em síntese, com base no estudo de caso da Estação Ecológica de Assis, nem a Resolução CONAMA 13/90 e nem a lei que institui o SNUC têm sido suficientes para garantir a eficácia da Zona de Entorno ou de Amortecimento em impedir que sejam instaladas obras e atividades que ofereçam ameaça à integridade dos recursos naturais das unidades de conservação. 


\section{CONSIDERAÇÕES FINAIS}

Com base na análise do aparato jurídico vigente, considera-se que a Zona de Amortecimento (SNUC) e a Zona de Entorno (Resolução CONAMA 13/90 - BRASIL, 1990b) podem ser classificadas como uma limitação administrativa, pois ambas impõem restrições ao exercício do direito de propriedade, com vistas à proteção dos recursos naturais.

Todavia, a instituição de uma área com limitações de uso ao redor das unidades de conservação no Brasil, ainda que bem intencionada, não se reveste da clareza e objetividade esperadas das leis.

Na prática, cabe aos gestores das unidades de conservação, juntamente com os órgãos licenciadores, indicar quais atividades devem ser submetidas a licenciamento ambiental para que possam ser instaladas em um raio de $10 \mathrm{~km}$ a partir do limite das unidades de conservação. Entende-se que esta indicação deve ser feita no Plano de Manejo, mas o SNUC, que trata do assunto, é omisso quanto à necessidade de licenciamento ambiental na Zona de Amortecimento. Ademais, a Zona de Amortecimento estabelecida no Plano de Manejo não coincide com a Zona de Entorno estabelecida na Resolução CONAMA 13/90 (BRASIL, 1990b).

$\mathrm{Na}$ falta de clareza desses institutos jurídicos, o Plano Diretor surge como uma oportunidade de extrema importância para que, dentro do ordenamento territorial dos municípios, as áreas ao redor das unidades de conservação sejam tratadas como zonas especiais, voltadas a mitigar os impactos sobre os recursos naturais das unidades de conservação.

Desse modo, a efetiva proteção das unidades de conservação por meio da limitação do uso das propriedades situadas ao seu redor depende, essencialmente, do entendimento entre o órgão gestor, os órgãos licenciadores e a administração municipal. E para que as normas estabelecidas não gerem conflitos, os proprietários da vizinhança devem ser envolvidos em todo o processo, de 
modo que tomem conhecimento das leis e compreendam as restrições de uso que lhes venham a ser impostas. 


\section{REFERÊNCIAS}

ACKERMAN, J. (2006). Oásis urbano. National Geographic, São Paulo, n.79, p.78-95, out.

AGUIRRE, A.A.; STARKEY, E. (1994). Wildlife disease in U.S. National Parks: historical and coevolutionary perspectives. Conservation Biology, Cambridge, v.8, n.3, p.654-661, Sept.

ALHO, C.J.R.; MARTINS, E.S. (Ed.). (1995). De Grão em grão o cerrado perde espaço: impactos do processo de ocupação. Brasília: WWF. Documento para discussão.

ALVES, V.R. (1992). Uso nocivo da propriedade. São Paulo: Revista dos Tribunais.

ASSOCIAÇÃO BRASILEIRA DE NORMAS TÉCNICAS (1992). NBR 8419: Apresentação de projetos de aterros sanitários de resíduos sólidos urbanos. Rio de Janeiro.

BARROSO, L.R. (1992). A Proteção do meio ambiente na constituição brasileira. Cadernos de Direito Constitucional e Ciência Política, São Paulo, v.1, p.115-140.

BASTOS, C.R. (1994). Curso de direito administrativo. São Paulo: Saraiva.

BEALE, C.M.; MONAGHAN, P. (2004). Human disturbance: people as predation-free predators?. Journal of Applied Ecology, Oxford, v.41, n.2, p.335-343, Apr.

BENSUSAN, N. (2001). Os Pressupostos biológicos do Sistema Nacional de Unidades de Conservação. In: BENJAMIM, A.H. (Coord.). Direito ambiental das áreas protegidas: o regime jurídico das unidades de conservação. Rio de Janeiro: Forense Universitária. p.164-189.

BOWMAN, D.M.J.S. (1998). Death of biodiversity - the urgent need for global ecology. Global Ecology and Biogeography Letters, Oxford, v.7, n.4, p.237-240.

BRASIL. (1934). Decreto Federal n²3. 793, de 23 de janeiro de 1934. Dispõe sobre o código florestal brasileiro. Diário Oficial da União, Brasília, DF, 24 jan.

. (1964). Lei $\mathrm{n}^{\circ} .4 .504$, de 30 de novembro de 1964. Dispõe sobre o estatuto da terra. Diário Oficial da União, Brasília, DF, 1 dez.

. (1965). Lei $\mathrm{n}^{\circ} .4771$, de 15 de setembro de 1965. Dispõe sobre o novo Código Florestal Brasileiro. Diário Oficial da União, Brasília, DF, 16 set.

. (1967). Lei $n^{\circ} .5197$, de 03 de janeiro de 1967. Dispõe sobre a proteção à fauna. Diário Oficial da União, Brasília, DF, 4 jan. 
. (1979a). Decreto $\mathrm{n}^{\circ} .84 .017$, de 21 de setembro de 1979. Dispõe sobre o regulamento dos parques nacionais brasileiros. Diário Oficial da União, Brasília, DF, 25 set.

(1979b). Lei $\mathrm{n}^{\circ} .6 .766$, de 19 de dezembro de 1979. Dispõe sobre o parcelamento do solo urbano. Diário Oficial da União, Brasília, DF, 20 dez.

. (1981). Lei ${ }^{0}$. 6.902, de 27 de abril de 1981. Dispõe sobre a criação de estações ecológicas e áreas de proteção ambiental. Diário Oficial da União, Brasília, DF, 28 abr.

. (1985). Lei no . 7.347, de 24 de julho de1985. Dispõe sobre a lei da ação civil pública. Diário Oficial da União, Brasília, DF, 25 jul.

. (1990a). Decreto Federal no . 99.274, de 6 de junho de 1990. Dispõe sobre a regulamentação da Lei $n^{\circ}$. 6.902/81, e a Lei nº.6.938/81. Diário Oficial da União, Brasília, DF, 7 jun.

. (1991). Lei ${ }^{\circ} .8 .171$, de 17 de janeiro de 1991. Dispõe sobre a política agrícola. Diário Oficial da União, Brasília, DF, 18 jan. 1991.

(1994). Decreto Legislativo $n^{\circ} 2$, de 03 de fevereiro de 1994. Dispõe sobre a convenção sobre diversidade biológica. Diário Oficial da União, Brasília, DF, 4 fev.

. (1998). Lei $n^{\circ} .9 .605$, de 12 de fevereiro de 1998. Dispõe sobre as sanções penais e administrativas derivadas de condutas e atividades lesivas ao meio ambiente. Diário Oficial da União, Brasília, DF, 13 fev. 1998.

. (2001a). Lei $\mathrm{n}^{\circ} .10 .257$, de 10 de julho de 2001. Dispõe sobre o estatuto da cidade. Diário Oficial da União, Brasília, DF, 11 jul.

. (2001b). Medida Provisória $\mathrm{n}^{\circ}$. 2.166-67, de 24 de agosto de 2001. Altera o artigo $4^{\mathrm{o}}$, $\overline{\text { caput } \mathrm{e}} \S \S 1^{\circ}$ a $7^{\circ}$, da Lei $\mathrm{n}^{\circ}$. 4.771, de 15 de setembro de 1965 (Código Florestal). Diário Oficial [da] República Federativa do Brasil, Brasília, DF, 25 ago.

(2001c). Decreto Federal no. 3.942, de 27 de setembro de 2001. Altera dispositivos do Decreto $\mathrm{n}^{\circ}$ 99.274/90. Diário Oficial da União, Brasília, DF, 28 set.

(2002a). Lei ${ }^{o}$. 10.406, de 10 de janeiro de 2002. Dispõe sobre o novo Código Civil Brasileiro. Diário Oficial da União, Brasília, DF, 11 jan.

(2002b). Decreto $\mathrm{n}^{\circ} .4340$, de 22 de agosto de 2002. Regulamenta artigos da Lei $\mathrm{n}^{\mathrm{o}}$ 9.985, de 18 de julho de 2000, que dispõe sobre o Sistema Nacional de Unidades de Conservação da Natureza. Diário Oficial da União, Brasília, DF, 23 ago.

BRASIL. Conselho Nacional do Meio Ambiente. (1986). Resolução CONAMA nº 01, 23 de janeiro de 1986. Define impacto ambiental. Diário Oficial da União, Brasília, DF, 17 fev. Seção I, p. 2548-2549. 
. (1990b). Resolução CONAMA nº 13, 06 de dezembro de 1990. Dispõe sobre o licenciamento ambiental no entorno de Unidades de Conservação. Diário Oficial da União, Brasília, DF, 28 dez. Seção I, p. 2541. Disponível $\mathrm{em}<$ http://www.mma.gov.br/port/conama/res/res90/res1390.html $>$. Acesso em: 1 jul. 2007.

(1993). Resolução CONAMA nº 10, de 1 de outubro de 1993. Dispõe sobre os estágios de sucessão da Mata Atlântica. Diário Oficial da União, Brasília, DF, 3 nov.

. (2002c). Resolução CONAMA n ${ }^{\circ}$. 307, de 5 de julho de 2002. Estabelece diretrizes, critérios e procedimentos para a gestão dos resíduos da construção civil. Diário Oficial da União, Brasília, DF, 17 jul.

BRASIL. Constituição. (1988). Constituição da República Federativa do Brasil. Brasília, DF: Senado.

BRITO, M.C.W. (2003). Unidades de conservação: intenções e resultados. 2.ed. São Paulo: Annablume.

CAÇA. (1077). In: FRANÇA, R.L. Enciclopédia saraiva de direito. São Paulo: Fernando Pereira Sodero. v.12, p.350.

CAMPOS, C.B. (2004). Impacto de cães (Canis familiaris) e gatos (Felis catus) errantes sobre a fauna silvestre em ambiente peri-urbano. 55f. Dissertação (Mestrado) - Escola Superior de Agricultura Luiz de Queiroz, Universidade de São Paulo, Piracicaba, 2004.

CASTANHO FILHO, E.P.; SCHWENCK JR., P.M. (2005). Florestas e zonas de amortecimento das unidades de conservação. Florestar Estatístico, São Paulo, v.8, n.17, p.17-24.

COBLENTZ, B.E. (1990). Exotic organisms: a dilemma for conservation biology.

Conservation Biology, Cambridge, v.4, n.3, p.261-265, Sept.

COMPANHIA DE TECNOLOGIA DE SANEAMENTO AMBIENTAL (2006). Inventário estadual de resíduos sólidos domiciliares / relatório de 2005. São Paulo: Secretaria de Estado do Meio Ambiente. (Série Relatórios).

CONSTANTINO, R. et al. (2003). Causas naturais. In: RAMBALDI, D.M.; OLIVEIRA, D.A.S. Fragmentação de ecossistemas: causas, efeitos sobre a biodiversidade e recomendações de políticas públicas. Brasília: MMA/SBF. Cap.2, p.44-63.

DERANI, C. (1997). Direito ambiental econômico. São Paulo: Max Limonad. . (2002). A Propriedade na constituição de 1988 e o conteúdo da "função social".

Revista de Direito Ambiental, São Paulo, v.1, n.27, p.58-68.

DI PIETRO, M.S.Z. (2006). Direito administrativo. 19.ed. São Paulo: Atlas.

DIAS, B.F.S. (2001). Demandas governamentais para o monitoramento da diversidade biológica 
brasileira. In: GARAY, I.E.G.; DIAS, B.F.S. Conservação da biodiversidade em ecossistemas tropicais: avanços conceituais e revisão de novas metodologias de avaliação e monitoramento. Petrópolis: Vozes. Cap.1, p.17-28.

DIEGUES, A.C.S. (2004). O Mito moderno da natureza intocada. 4.ed. São Paulo: Hucitec.

DURIGAN, G. (2003). Bases e diretrizes para a restauração da vegetação de cerrado. In:

KAGEYAMA, P.Y. et al. Restauração ecológica de ecossistemas naturais. Botucatu: FEPAF.

DURIGAN, G. et al. (1995). Plano de manejo da estação ecológica de Assis. São Paulo:

Secretaria do Meio Ambiente; Instituto Florestal.

Presença de gado no cerrado. 2005. 1 fotografia.

FIEDLER, N.C. et al. (2004). Efeito de incêndios florestais na estrutura e composição florística de uma área de cerrado sensu stricto na fazenda Água Limpa - DF. Revista Árvore, Viçosa, v.28, n.1, p.129-138, fev.

FIGUEIREDO, G.J.P.; LEUZINGER, M. D. (2001). Desapropriações Ambientais na Lei $\mathrm{n}^{\circ}$. 9.985/00. In: BENJAMIM, A.H. Direito ambiental das áreas protegidas: o regime jurídico das unidades de conservação. Rio de Janeiro: Forense Universitária. p. 465-489.

FIGUEIREDO, G.J.P. (2004). A Propriedade no direito ambiental. Rio de Janeiro: Esplanada.

FISZON, J.T. et al. (2003). Atividades antrópicas e fatores de impacto na fragmentação. In: RAMBALDI, D.; SOARES, D.A. Efeitos da fragmentação de habitats: recomendações de políticas públicas. Brasília: MMA/SBF. Cap.3, p.66 -99.

FORESTER, D.J.; MACHLIS, G.E. (1996). Modeling human factors that affect the loss of biodiversity. Conservation Biology, Cambridge, v.10, n.4, p.1253-1263.

GASPARINI, D. (2002). Direito administrativo. 7.ed. São Paulo: Saraiva.

GONÇALVES, J.C.S.; DUARTE, D.H.S. (2006). Arquitetura sustentável: uma integração entre ambiente, projeto e tecnologia em experiências de pesquisa, prática e ensino. Ambiente

Construído, Porto Alegre, v.6, n.4, p.51-81.

GÖTMARK, F.B.; SÖDERLUNDH, H.; THORELL, M. (2000). Buffer zones for forest reserves: opinions of land owners and conservation value of their forest around nature reserves in southern Sweden. Biodiversity and Conservation, v.9, n.10, p.1377-1390, Oct.

GRIGERA, D.E.; RAPOPORT, E.H. (1983). Status and distribution of the European Hare in South America. Journal of Mammalogy, Baltimore, v.64, p.163-166.

HAILA, Y. (1999). Islands and fragments. HUNTER JÚNIOR, M.L. Maintaining biodiversity in forest ecosystems. Cambridge: Cambridge University Press. Cap.7, p.234-264. 
HAMADA, J. (1997). Estimativas de geração e caracterização do chorume em aterros sanitários. In: CONGRESSO BRASILEIRO DE ENGENHARIA SANITÁRIA E AMBIENTAL, 19.,1997, Foz do Iguaçu. Anais.... Foz do Iguaçu: Associação Brasileira de Engenharia Sanitária e Ambiental, 1997.

ISHIHATA, L. (1999). Bases para seleção de áreas prioritárias para implementação de unidades de conservação em regiões fragmentadas. 200f. Dissertação (Mestrado) PROCDM - Ciência Ambiental, Universidade de São Paulo, São Paulo, 1999.

KLINK, C.A.; MOREIRA, A. (Ed.). (2002). Past and current human occupation, and land use. In: OLIVEIRA, P.S.; MARQUIS, R.J. Ecology and natural history of a neotropical savanna. New York: Columbia University Press. p.69-88.

KRONKA, F.J.N. et al. (1998). Áreas de domínio do cerrado no Estado de São Paulo. São Paulo: Secretaria do Meio Ambiente.

. (2005). Inventário florestal da vegetação natural do Estado de São Paulo. São

Paulo: Secretaria do Meio Ambiente; Instituto Florestal, Imprensa Oficial.

MACHADO, P.A.L. (2002). Direito Ambiental Brasileiro. 10.ed. São Paulo: Malheiros. (2007). Direito Ambiental Brasileiro. 15.ed. São Paulo: Malheiros.

MAX, J.C.M. et al. (2004a). Plano de desenvolvimento sustentável para o entorno da estação ecológica de Assis. São Paulo: Secretaria do Meio Ambiente; Instituto Florestal. (Série Registros). No prelo.

. (2004b). Plano de desenvolvimento sustentável para o entorno da estação ecológica de Assis. In: CONGRESSO BRASILEIRO DE UNIDADES DE CONSERVAÇÃO, 4., 2004, Curitiba. Anais... Curitiba: Fundação O Boticário de Proteção à Natureza; Rede Nacional Pró Unidades de Conservação. p.560-569.

MEIRELLES, H.L. (1992). Direito administrativo brasileiro. 17.ed. São Paulo: Malheiros.

MILARÉ, E. (2007). Direito do ambiente: doutrina, jurisprudência, glossário. 5.ed. São Paulo: Revista dos Tribunais.

MONTEIRO, J.H.P. et al. (2001). Manual de gerenciamento integrado de resíduos sólidos. Rio de Janeiro: IBAM.

MORAES, L.C.S. (2002). Código florestal comentado. 3.ed. São Paulo: Atlas.

MORSELLO, C. (2001). Áreas protegidas públicas e privadas: seleção e manejo. São Paulo: Annablume.

MOSELEY, J.; THELEN, K.; MILLER, K. (1976). National parks planning. FAO: Forestry 
paper, Roma, v.6.

MURAKAMI, S. et al. (2002). Sustainable building and policy design. Tokio: Institute of International Harmonization for Building and Housing.

NASSARO, M.R.F. (2004). Atos e modalidades de caça: comentários do artigo 204 da Constituição Estadual. In: CONGRESSO INTERNACIONAL DE DIREITO AMBIENTAL, 8., 2004, São Paulo. Anais... São Paulo: Direito por um Planeta Verde. p.575-592.

NERY JUNIOR, N.; NERY, R.M.A. (2002). Novo código civil e legislação extravagante anotados. São Paulo: Revista dos Tribunais.

NEUMANN, R.P. (1997). Primitive ideas: protected area buffer zones and the politics of land in Africa. Development and Change, The Hague, v.28, n.3, p.559-582, July.

OLIVA, A. (2003). Programa de manejo fronteiras para o Parque Estadual Xixová-Japuí SP. 239f. Dissertação (Mestrado) - Escola Superior de Agricultura Luiz de Queiroz, Universidade de São Paulo, Piracicaba, 2003.

OLIVA, A.; COSTA NETO, J.B. (2004). Contribuição para o planejamento da aplicação de compensação financeira a impactos de obras em unidades de conservação. In: CONGRESSO BRASILEIRO DE UNIDADES DE CONSERVAÇÃO, 4., 2004, Curitiba. Anais... Curitiba: Fundação O Boticário de Proteção à Natureza; Rede Brasileira de Unidades de Conservação. v.1, p.510-520.

OLIVEIRA, A.D. et al. (2002). Avaliação econômica da regeneração da vegetação de cerrado, sob diferentes regimes de manejo. Revista Árvore, Viçosa, v.26, n.6, p.715-726, nov.

OLIVEIRA, F.J.S.; JUCÁ, J.F.T. (2004). Acúmulo de metais pesados e capacidade de impermeabilização do solo imediatamente abaixo de uma célula de um aterro de resíduos sólidos. Engenharia Sanitária e Ambiental, Rio de Janeiro, v.9, n.3, p.211-217, jul./set.

ORLANDO, M. (1997). Áreas de conservação ou "ilhas" isoladas. Revista de Direito Ambiental, São Paulo, n.7, p.27-33, jul./set.

PADUA, C.V.; PADUA, S.M.; CULLEN JUNIOR, L. (2002). Within and surrounding the Morro do Diabo State Park: biological value, conflicts, mitigation and sustainable development alternatives. Environmental Science \& Policy, Amsterdam, v.5, n.1, p.69-78, Feb.

PÁDUA, M.T.J.; PORTO, E.L.R. (1979). Plano do sistema de unidades de conservação do Brasil. Brasília: IBDF.

PAUCHARD, A. et al. (2006). Multiple effects of urbanization on the biodiversity of developing countries: the case of a fast-growing metropolitan area (Concepción, Chile). Biological

Conservation, Barking, v.127, n.3, p.272-281, Jan. 
PIMENTEL, D. et al. (1992). Conserving biological diversity in agricultural/forestry systems. BioSciences, Washington, v.42, n.5, p.354-462, May.

PINTO, A.L.T.; WINDT, M.C.; SIQUEIRA, L.E.A. (2001). Interesses difusos e coletivos: sistema nacional de unidades de conservação. 3.ed. São Paulo: Saraiva. p.514-530.

. (Coord.). (2001). Interesses difusos e coletivos: política nacional do meio ambiente. 3.ed. São Paulo: Saraiva.

PINTO, T.P. (1999). Metodologia para a gestão diferenciada de resíduos sólidos da construção urbana. 189f. Tese (Doutorado) - Escola Politécnica, Universidade de São Paulo, São Paulo, 1999.

POSSAMAI, F.P. et al. (2007). Lixões inativos na região carbonífera de Santa Catarina: análise dos riscos à saúde pública e ao meio ambiente. Ciência \& Saúde Coletiva, Rio de Janeiro, v.12, n.1, p.171-179, jan./mar.

PREFEITURA MUNICIPAL DE ASSIS (2006). Lei complementar $n^{\circ} 10$, de 10 de outubro de 2006. Institui o plano diretor municipal. Assis.

PRIMACK, R.B.; RODRIGUES, E. (2001). Biologia da conservação. Londrina: Efraim Rodrigues.

RATTER, J.A.; BRIDGEWATER, S.; RIBEIRO, J.F. (2006). Biodiversity patterns of the woody vegetation of the Brazilian Cerrado. In: PENNINGTON, P.T.; GWILYM, L.; RATTER, F.A. (Org.). Neotropical savannas and dry forests: diversity, biogeography and conservation. Boca Raton: Taylor e Francis. P.31-66. (Systematics Association Special Volumes, 69).

RATTER, J.A.; RIBEIRO, J.F.; BRIDGEWATER, S. (1997). The Brazilian cerrado vegetation and threats to its biodiversity. Annals of Botany, Oxford, v.80, n.3, p.223-230, Sept.

RODRIGUES, G.S. (2001). Impacto das atividades agrícolas sobre a biodiversidade: causas e conseqüências. In: GARAY, I.E.G.; DIAS, B.F.S. Conservação da biodiversidade em ecossistemas tropicais: avanços conceituais e revisão de novas metodologias de avaliação e monitoramento. Petrópolis: Vozes. Cap.2, p.128-139.

SANTOS, S.C.H. (2003). Direito ambiental: unidades de conservação - limitações administrativas. 2.ed. Curitiba: Juruá.

SÃO PAULO (Estado). (1992). Decreto Estadual no. 35.697, de 21 de setembro 1992. Dispõe sobre a criação da Estação Ecológica de Assis. Diário Oficial do Estado, São Paulo, 22 set.

SÃO PAULO (Estado). (2002). Decreto Estadual $n^{\circ} .47 .097$, de 18 de setembro 2002. Dispõe sobre a ampliação da Estação Ecológica de Assis. Diário Oficial do Estado, São Paulo, 19 de set. 
SÃO PAULO. Constituição (1989). Constituição do Estado de São Paulo. São Paulo, SP: Assembléia Legislativa, 1989.

SAUNDERS, D.A.; HOBBS, R.J.; MARGULES, C.R. (1991). Biological consequences of ecosystem fragmentation: a review. Conservation Biology, Cambridge, v.5, n.1, p.18-32, Mar.

SCHNEIDER, D.M.; PHILIPPI JUNIOR, A. (2004). Gestão pública de resíduos da construção civil no município de São Paulo. Ambiente Construído, Porto Alegre, v.4, n.4, p.21-32, out./dez.

SILVA, J.A. (2006). Direito urbanístico brasileiro. 4.ed. São Paulo: Malheiros.

SISINNO, C.L.S.; MOREIRA, J.C. (1996). Avaliação da contaminação e poluição ambiental na área de influência do aterro controlado do Morro do Céu, Niterói, Brasil. Cadernos de Saúde Pública, Rio de Janeiro, v.12, n.4, p.515-523, out./dez.

SMALLWOOD, K.S. (1994). Site invasibility by exotic birds and mammals. Biological Conservation, Barking, v.69, n.3, p.251-259.

SOULÉ, M.E. (1991). Conservation: tactics for a constant crises. Science, Washington, v.253, n.5021, p.744-750, Aug.

UNITED NATIONS EDUCATIONAL, SCIENTIFIC AND CULTURAL ORGANIZATION. (1996). Biosphere Reserves: the seville strategy and the statutory framework of the world network. Paris: UNESCO.

VIO, A.P.A. (2001). Zona de amortecimento e corredores ecológicos. In: BENJAMIM, A.H. Direito ambiental das áreas protegidas: o regime jurídico das unidades de conservação. Rio de Janeiro: Forense Universitária. p.348-360.

WILSON, E.O. (1997). A Situação atual da diversidade biológica. In: WILSON, E.O.; PETER, F.M. Biodiversidade. Rio de Janeiro: Nova Fronteira. Cap.1, p.3-24. 
ANEXOS 


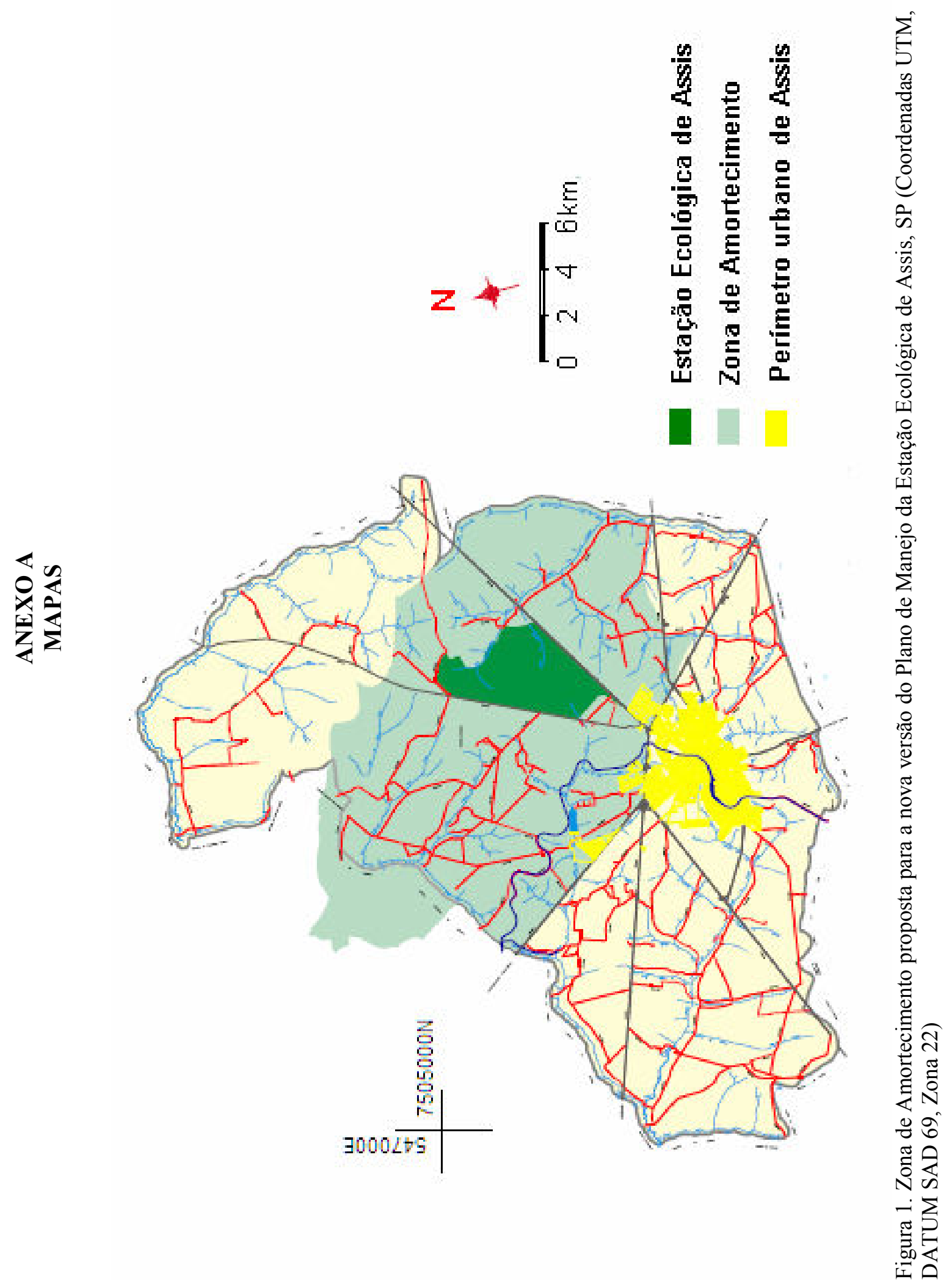



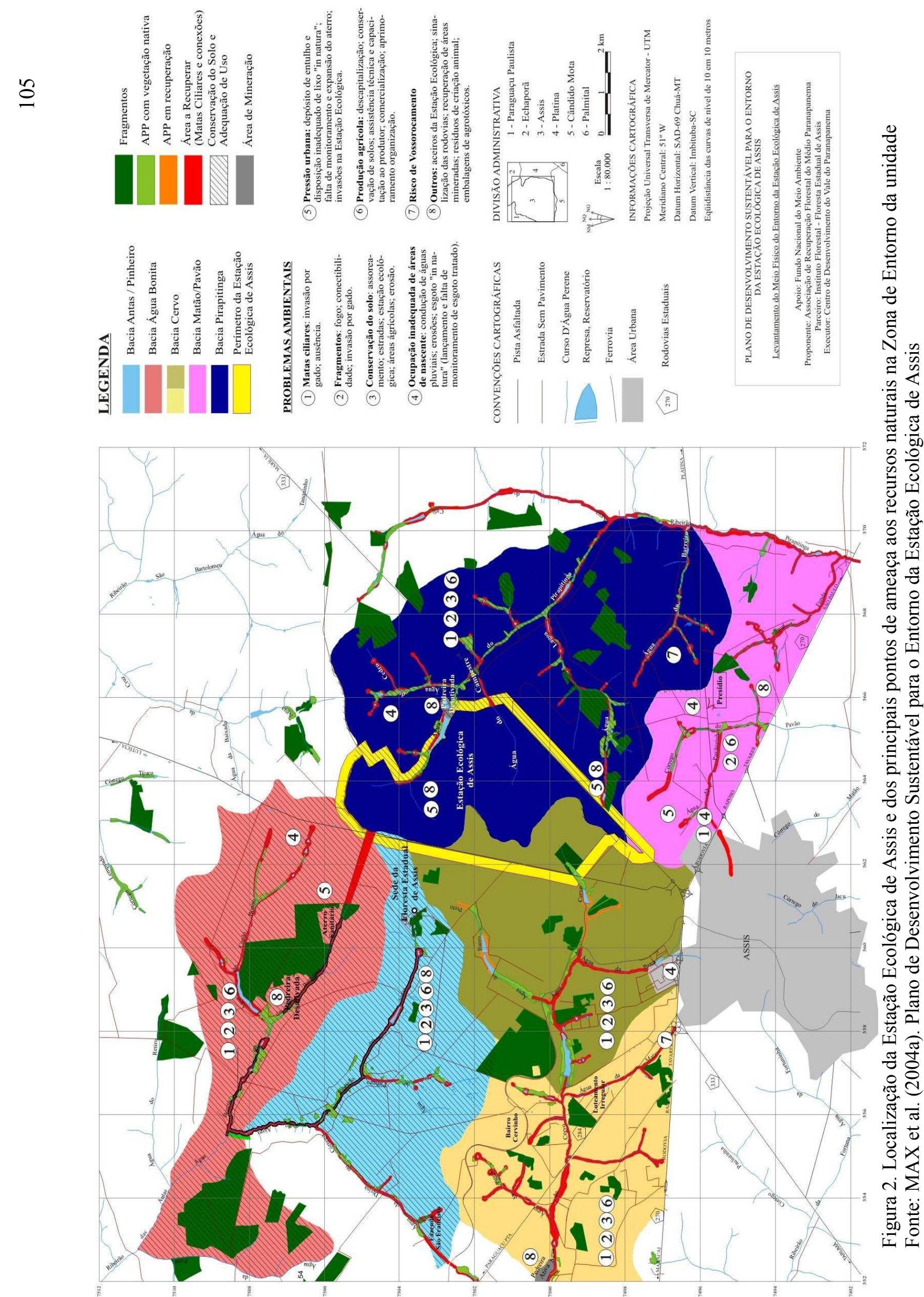


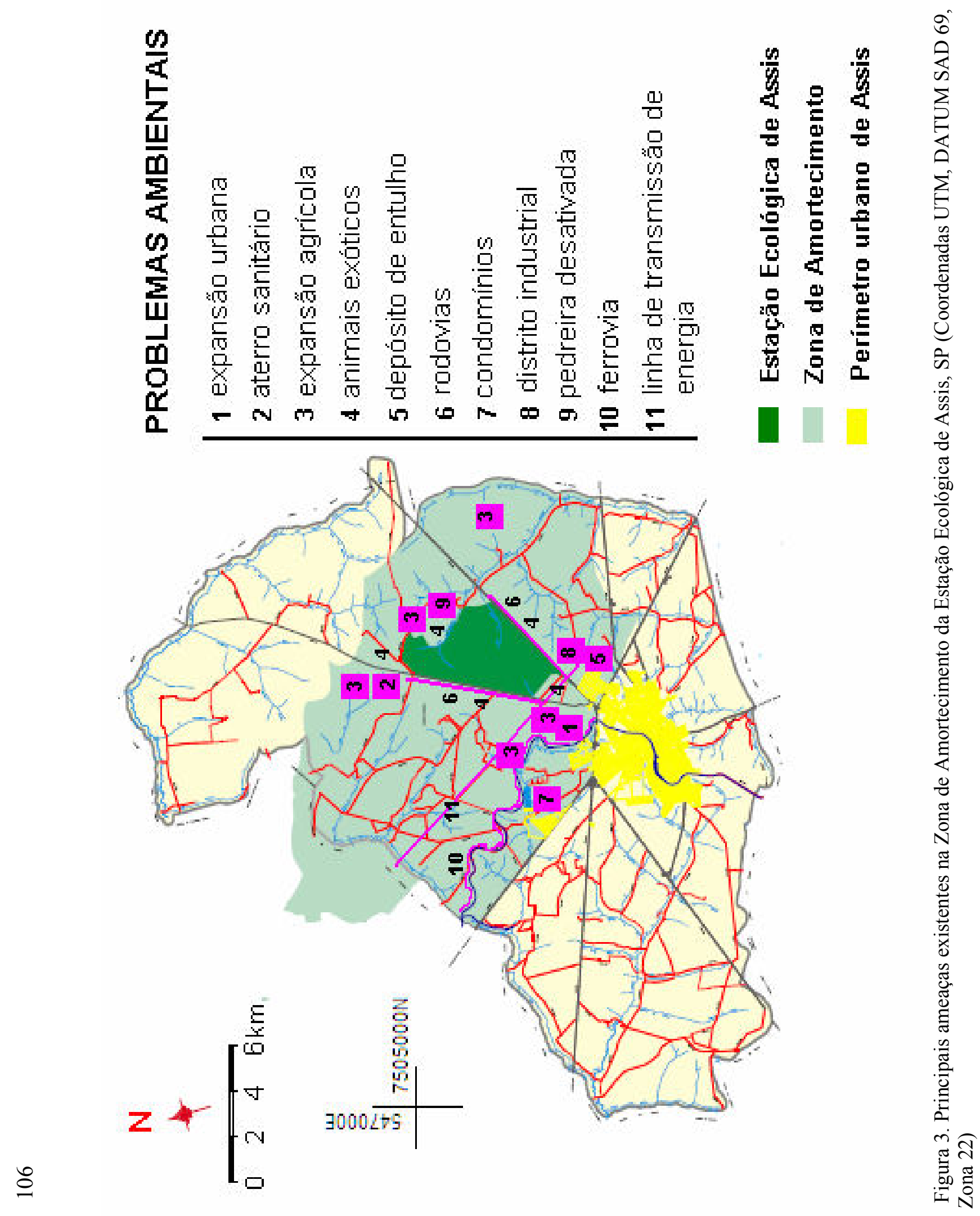




\section{ANEXO B}

Figuras das principais atividades impactantes instaladas na Zona de Entorno da Estação Ecológica de Assis (SP).

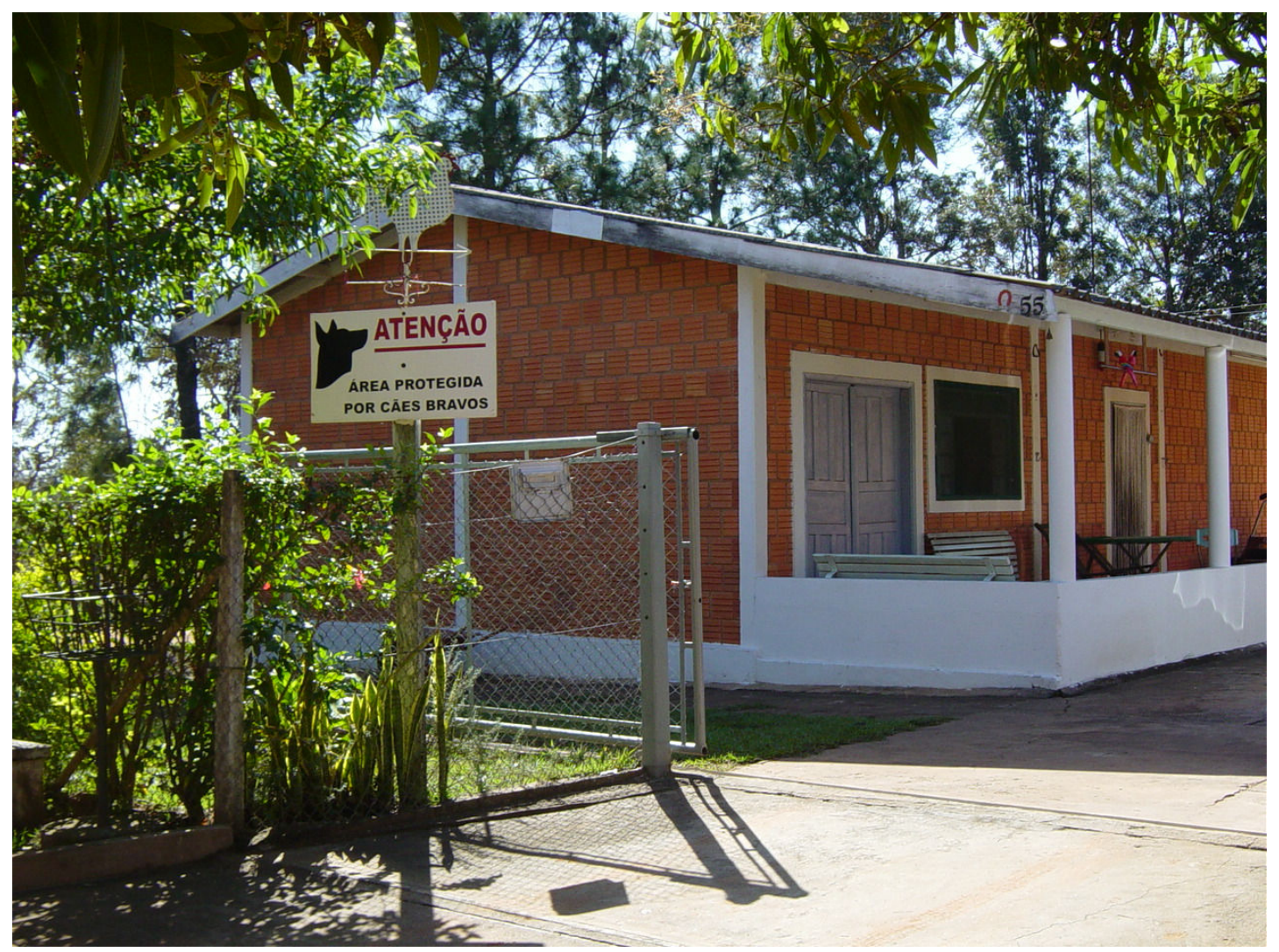

Figura 4. Condomínio para fins residenciais construído na Zona de Entorno da EEcA 


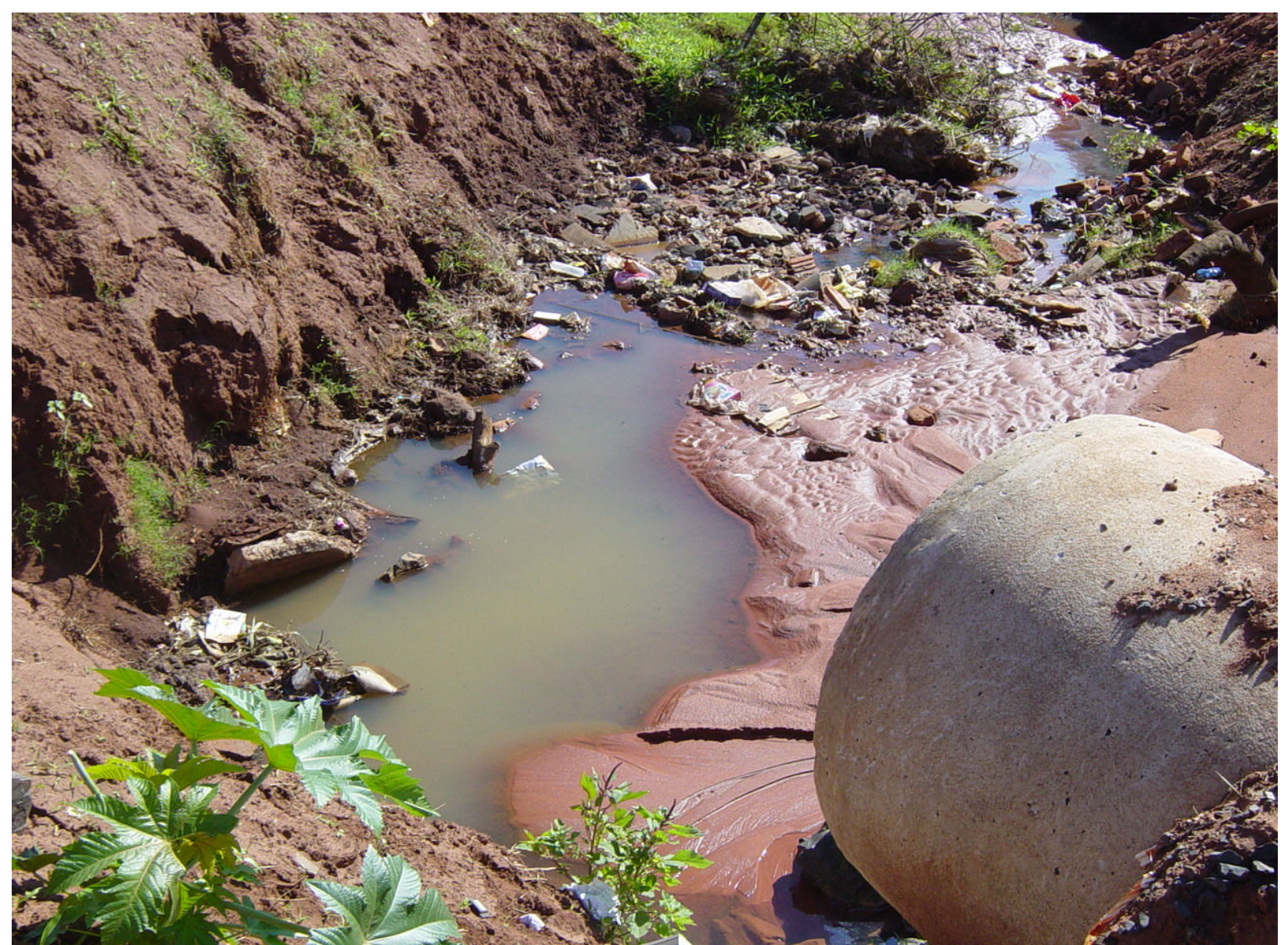

Figura 5. Ocupação desordenada, drenagem, esgoto, lixo e entulho na Água da Porca, município de Assis, SP 


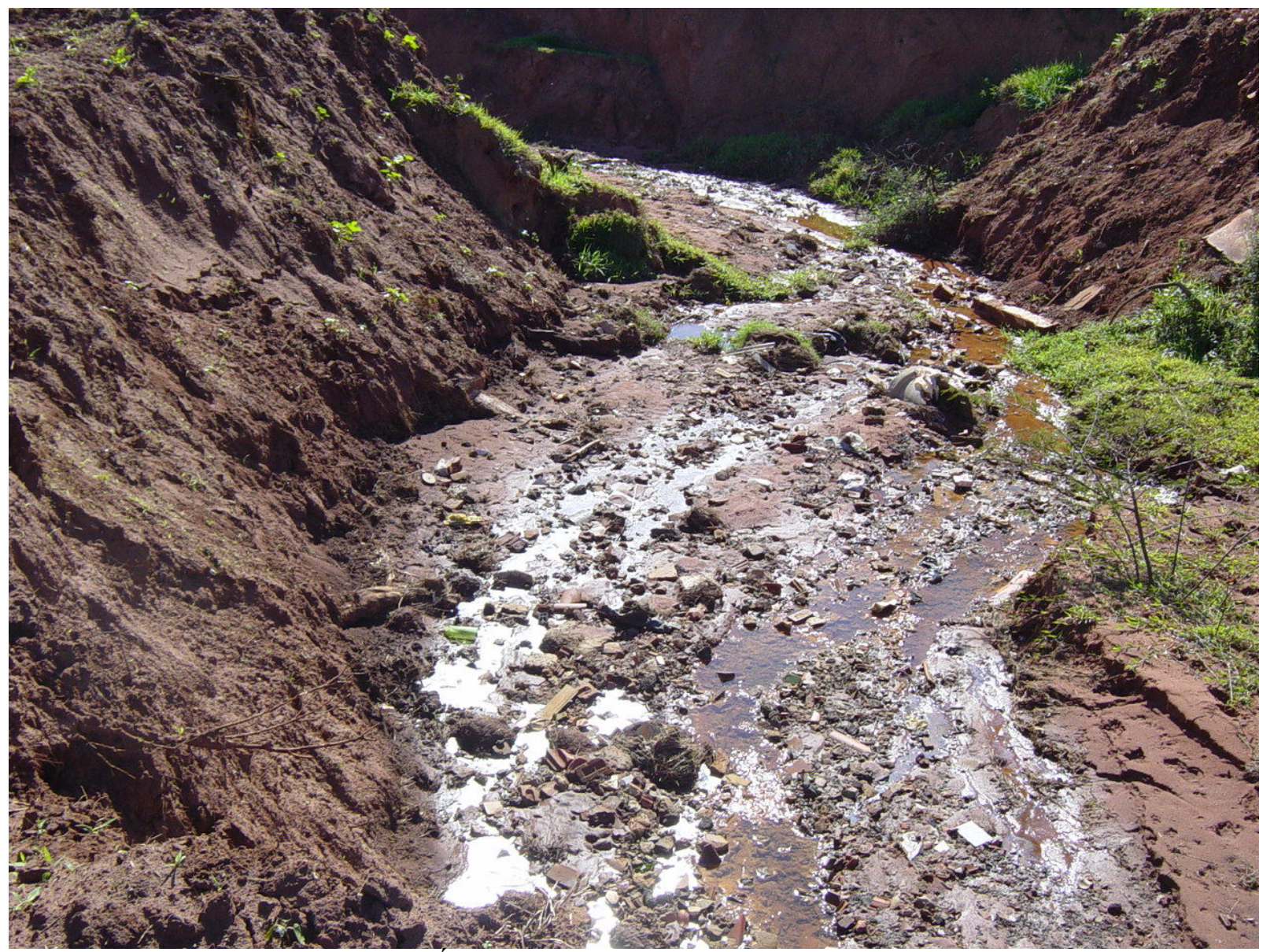

Figura 6. Erosão e assoreamento na Agua da Porca, município de Assis, SP 


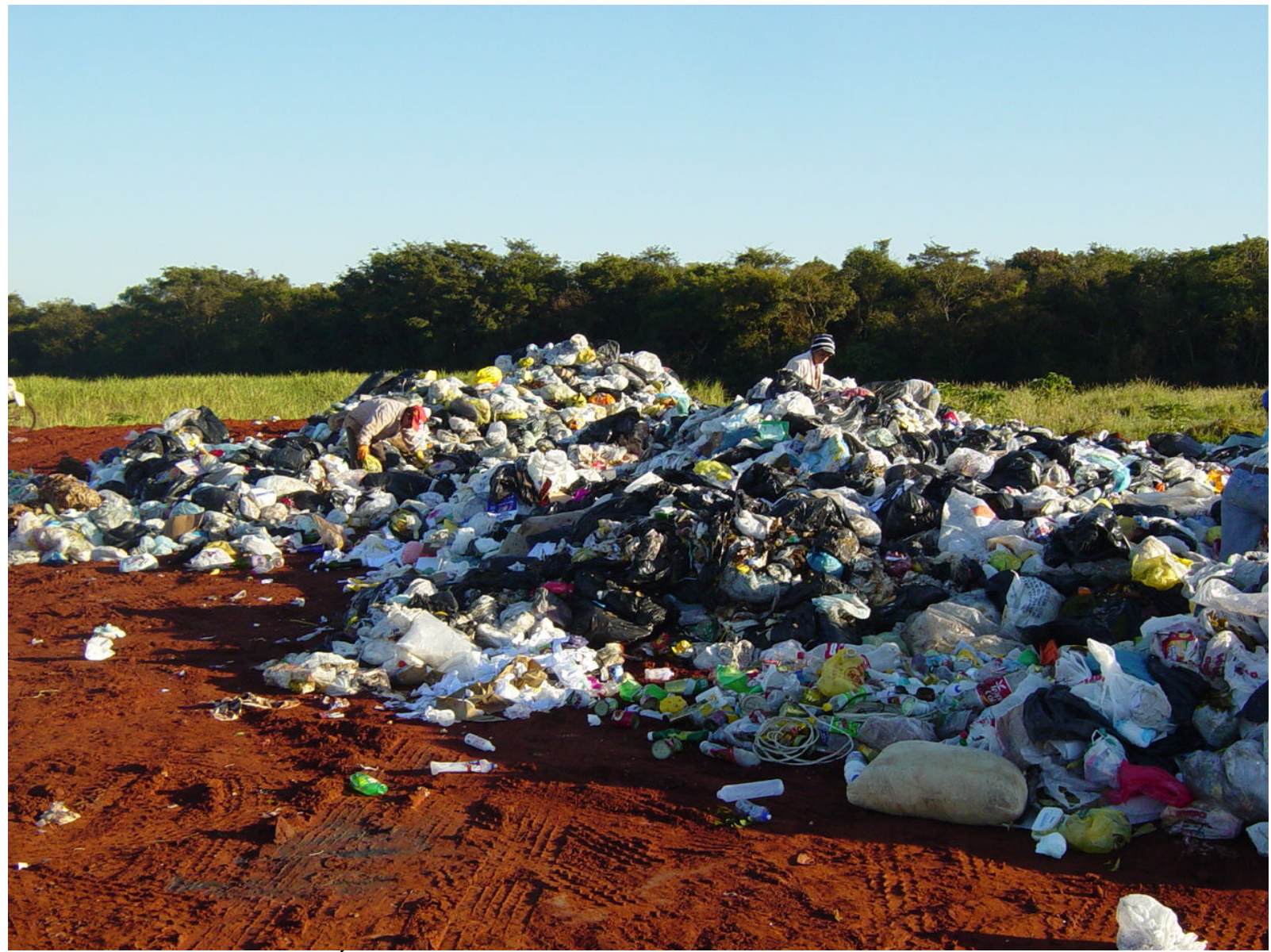

Figura 7. Aterro Sanitário (Água da Roça ou Pontinha), no interior da Zona de Entorno da EEcA 


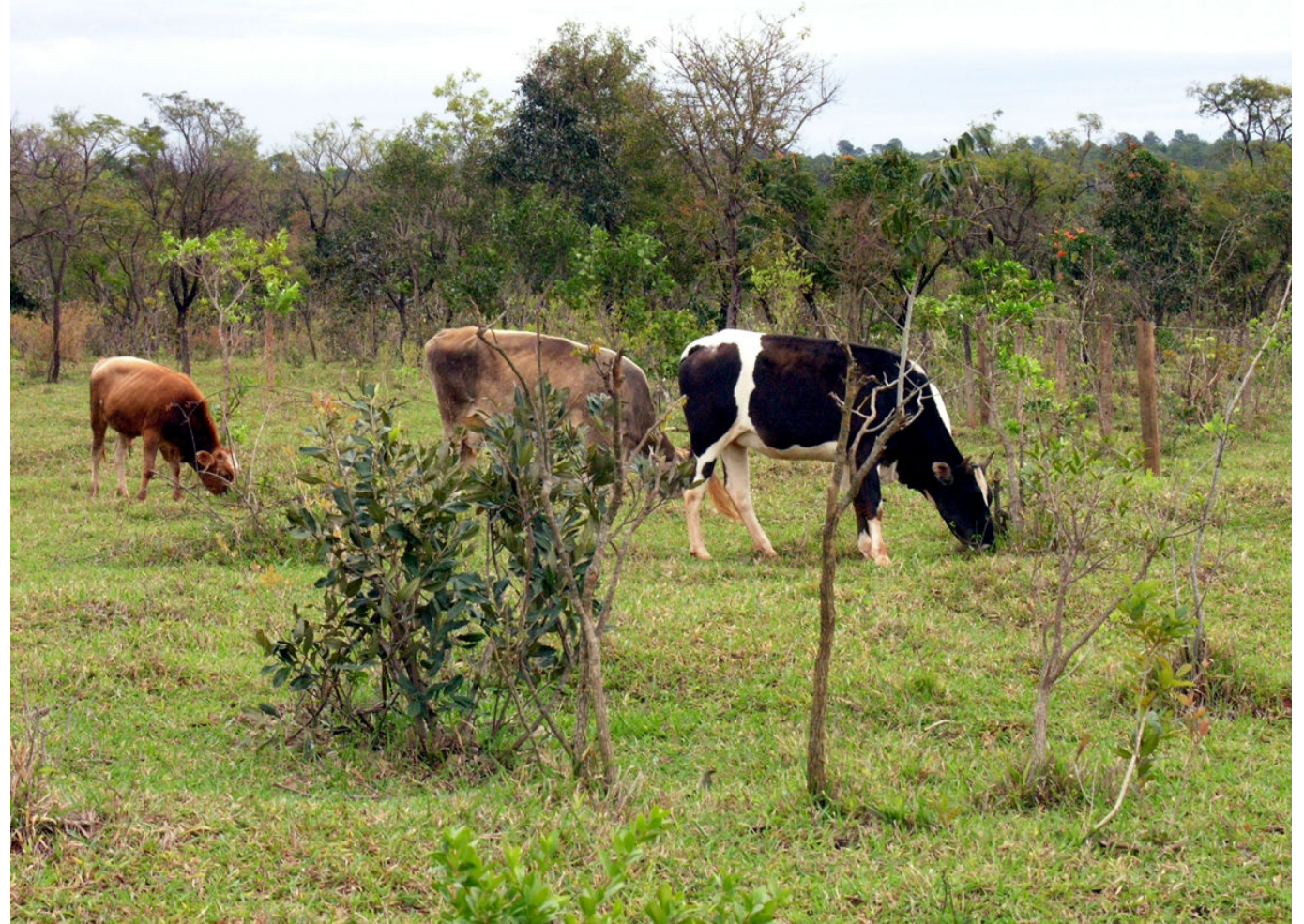

Figura 8. Presença de gado na ZA da EEcA

Fonte: Durigan (2005)

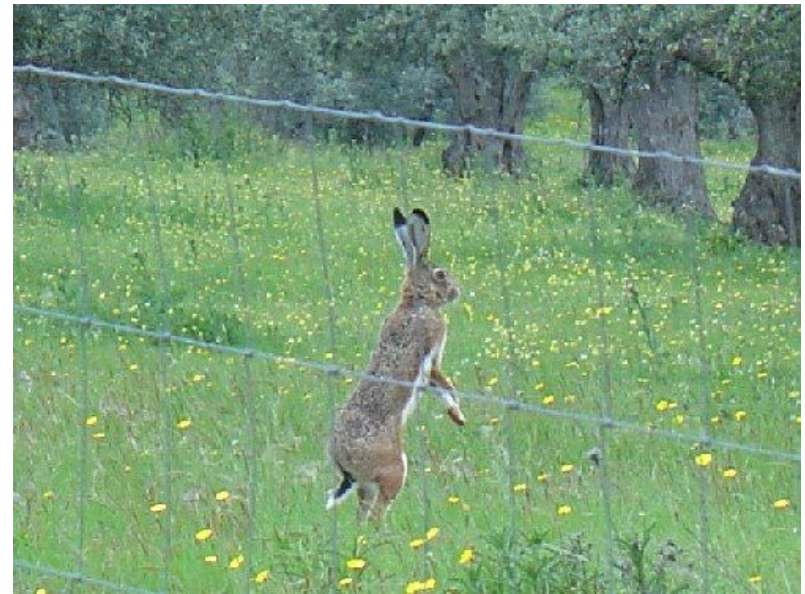

Figura 9. Lebrão

Fonte: http://serra-da-adica.blogspot.com

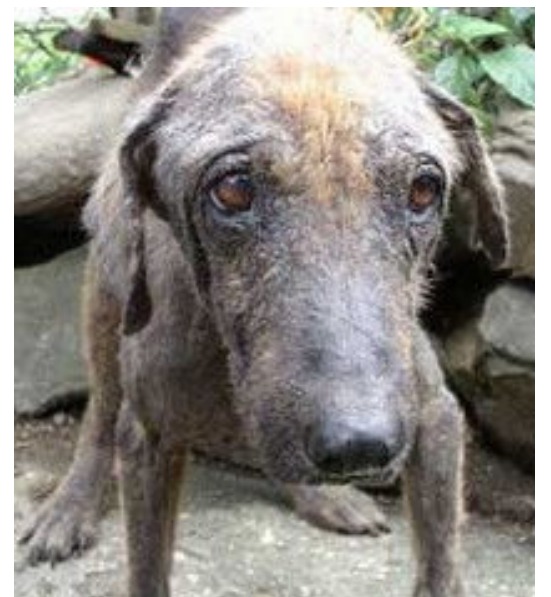

Figura 10. cachorro

Fonte: www.wspabrasil.org 


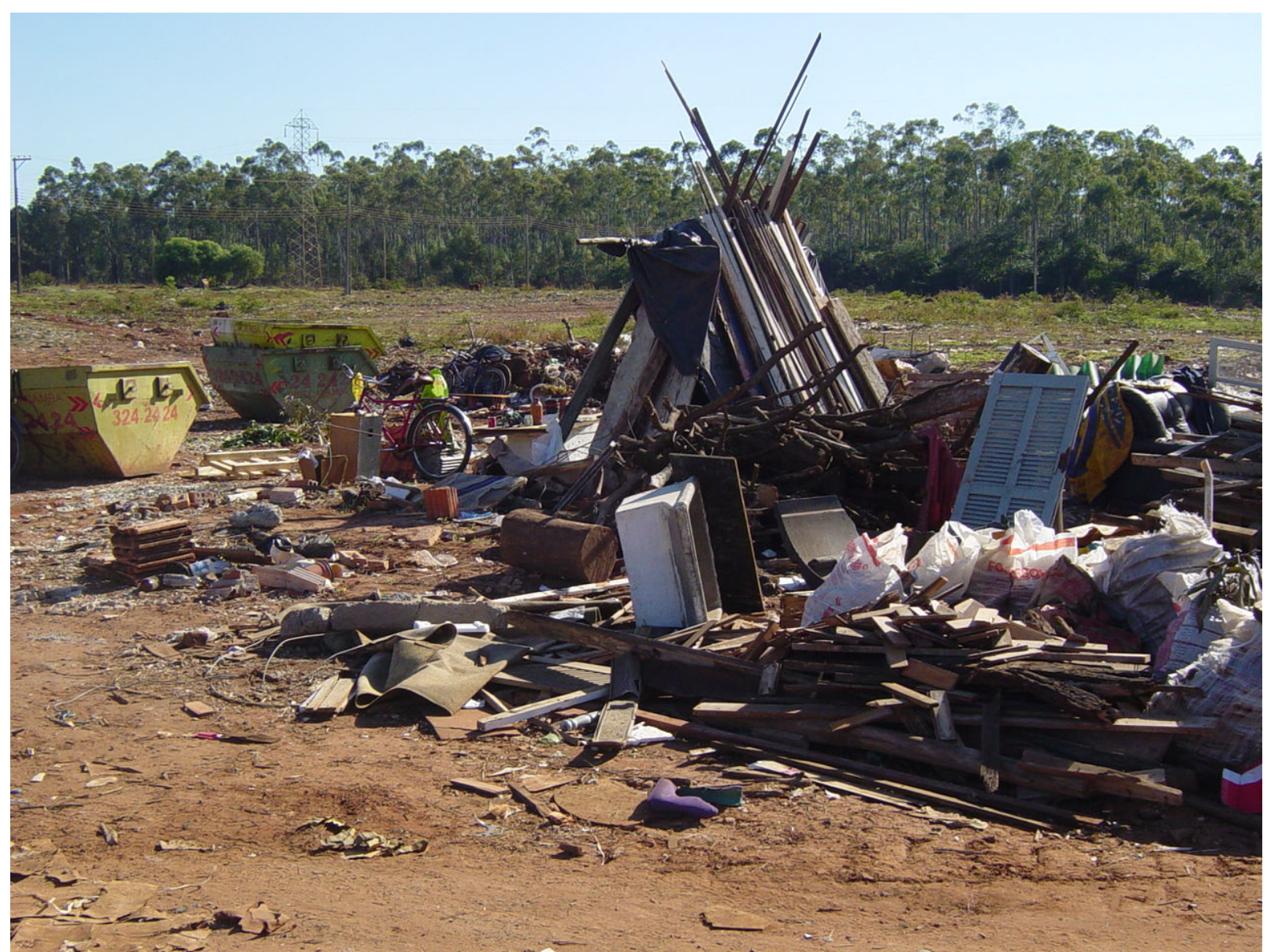

Figura11. Depósito de entulho a montante da nascente da Água do Pavãozinho, na Zona de Entorno da Estação Ecológica de Assis, SP 


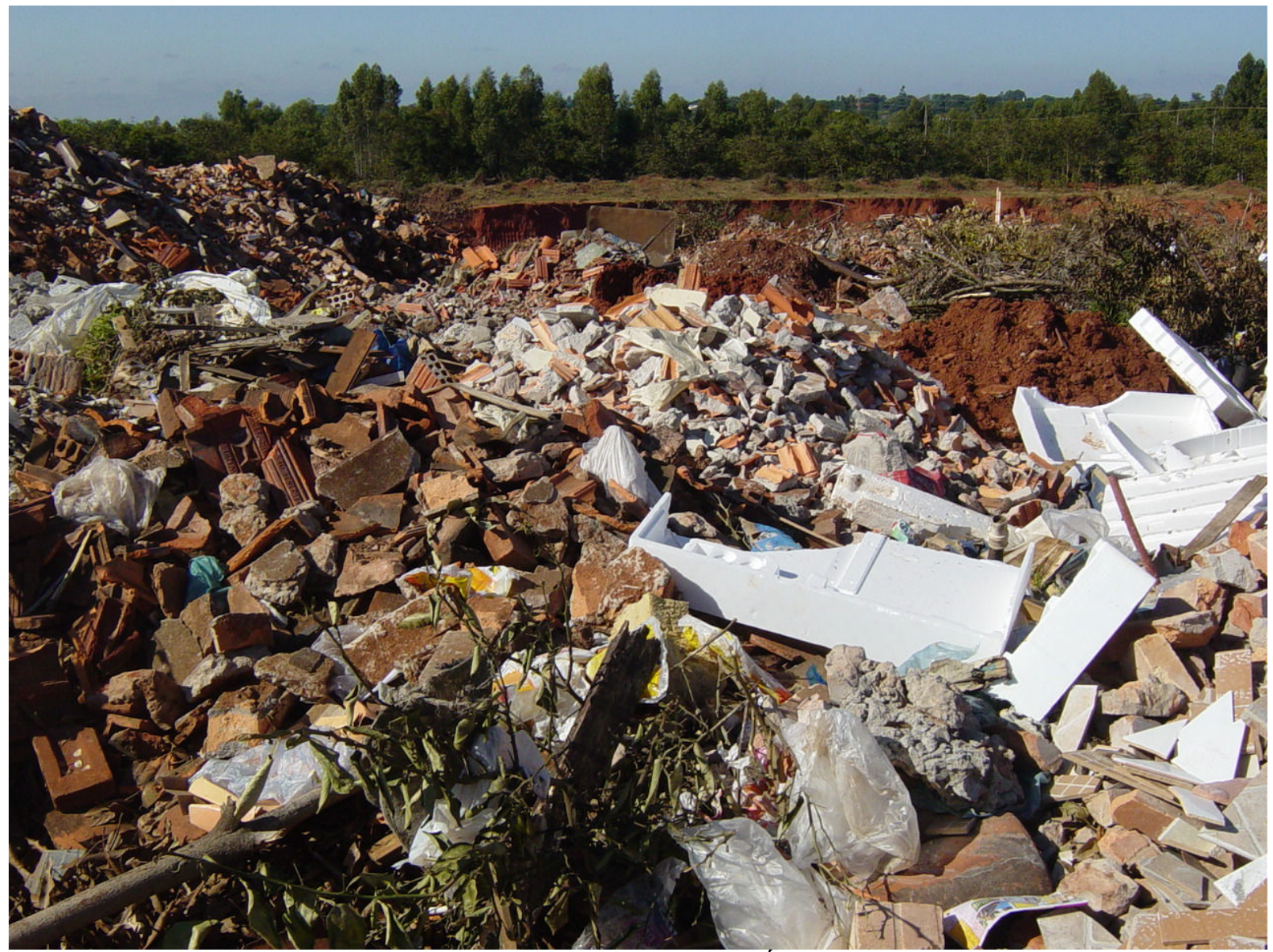

Figura 12. Depósito de entulho a montante da nascente da Água do Pavãozinho, dentro da Zona de Entorno da Estação Ecológica de Assis, SP 


\section{ANEXO C \\ Relação da principal legislação utilizada na pesquisa}

\section{RESOLUÇÃO CONAMA nº 013 de 06 de dezembro de 1990}

Publicada no D.O.U, de 28/12/90, Seção I, Pág. 25.541.

O CONSELHO NACIONAL DO MEIO AMBIENTE - CONAMA, no uso das atribuições que lhe são conferidas pela Lei $\mathrm{n}^{\mathrm{o}}$. 6.938, de 31 de agosto de 1981, alterada pela Lei $\mathrm{n}^{\circ} .8 .028$, de 12 de abril de 1990, regulamentadas pelo Decreto $\mathrm{n}^{\circ}$. 99.274, de 06 de junho de 1990, e tendo em vista o disposto em seu Regimento Interno, e

Considerando o disposto nos artigos $7^{\circ}$ e 27 , Decreto $n^{\circ} .99 .274$, de 06/06/90.

Considerando a necessidade de estabelecer-se, com urgência normas referentes ao entorno das Unidades de Conservação visando a proteção dos ecossistemas ali existentes, RESOLVE:

Art. $1^{\circ}$ - O órgão responsável por cada Unidade de Conservação, juntamente com os órgãos licenciadores e de meio ambiente, definirá as atividades que possam afetar a biota da Unidade de Conservação.

Art. $2^{\circ}$ - Nas áreas circundantes das Unidades de Conservação, num raio de dez quilômetros, qualquer atividade que possa afetar a biota, deverá ser obrigatoriamente licenciada pelo órgão ambiental competente.

Parágrafo Único - O licenciamento a que se refere o caput deste artigo só será concedido mediante autorização do responsável pela administração da Unidade de Conservação.

Art. $3^{\circ}$ - Esta Resolução entra em vigor na data de sua publicação.

Tânia Maria Tonelli Munhoz José A. Lutzenberger 


\section{LEI N ${ }^{0}$ 9.985, DE 18 DE JULHO DE 2000.}

Regulamenta o art. 225, $\S 1^{1}$, incisos I, II, III e VII da Constituição Federal, institui o Sistema Nacional de Unidades de Conservação da Natureza e dá outras providências.

O VICE-PRESIDENTE DA REPÚBLICA no exercício do cargo de PRESIDENTE DA REPÚBLICA Faço saber que o Congresso Nacional decreta e eu sanciono a seguinte Lei:

\section{CAPÍTULO I \\ DAS DISPOSIÇÕES PRELIMINARES}

Art. $1^{\circ}$ Esta Lei institui o Sistema Nacional de Unidades de Conservação da Natureza - SNUC, estabelece critérios e normas para a criação, implantação e gestão das unidades de conservação.

Art. $2^{\underline{o}}$ Para os fins previstos nesta Lei, entende-se por:

I - unidade de conservação: espaço territorial e seus recursos ambientais, incluindo as águas jurisdicionais, com características naturais relevantes, legalmente instituído pelo Poder Público, com objetivos de conservação e limites definidos, sob regime especial de administração, ao qual se aplicam garantias adequadas de proteção;

II - conservação da natureza: o manejo do uso humano da natureza, compreendendo a preservação, a manutenção, a utilização sustentável, a restauração e a recuperação do ambiente natural, para que possa produzir o maior benefício, em bases sustentáveis, às atuais gerações, mantendo seu potencial de satisfazer as necessidades e aspirações das gerações futuras, e garantindo a sobrevivência dos seres vivos em geral;

III - diversidade biológica: a variabilidade de organismos vivos de todas as origens, compreendendo, dentre outros, os ecossistemas terrestres, marinhos e outros ecossistemas aquáticos e os complexos ecológicos de que fazem parte; compreendendo ainda a diversidade dentro de espécies, entre espécies e de ecossistemas;

IV - recurso ambiental: a atmosfera, as águas interiores, superficiais e subterrâneas, os estuários, o mar territorial, o solo, o subsolo, os elementos da biosfera, a fauna e a flora;

V - preservação: conjunto de métodos, procedimentos e políticas que visem a proteção a longo prazo das espécies, habitats e ecossistemas, além da manutenção dos processos ecológicos, prevenindo a simplificação dos sistemas naturais;

VI - proteção integral: manutenção dos ecossistemas livres de alterações causadas por interferência humana, admitido apenas o uso indireto dos seus atributos naturais; 
VII - conservação in situ: conservação de ecossistemas e habitats naturais e a manutenção e recuperação de populações viáveis de espécies em seus meios naturais e, no caso de espécies domesticadas ou cultivadas, nos meios onde tenham desenvolvido suas propriedades características;

VIII - manejo: todo e qualquer procedimento que vise assegurar a conservação da diversidade biológica e dos ecossistemas;

IX - uso indireto: aquele que não envolve consumo, coleta, dano ou destruição dos recursos naturais;

$\mathrm{X}$ - uso direto: aquele que envolve coleta e uso, comercial ou não, dos recursos naturais;

XI - uso sustentável: exploração do ambiente de maneira a garantir a perenidade dos recursos ambientais renováveis e dos processos ecológicos, mantendo a biodiversidade e os demais atributos ecológicos, de forma socialmente justa e economicamente viável;

XII - extrativismo: sistema de exploração baseado na coleta e extração, de modo sustentável, de recursos naturais renováveis;

XIII - recuperação: restituição de um ecossistema ou de uma população silvestre degradada a uma condição não degradada, que pode ser diferente de sua condição original;

XIV - restauração: restituição de um ecossistema ou de uma população silvestre degradada o mais próximo possível da sua condição original;

XV - (VETADO)

XVI - zoneamento: definição de setores ou zonas em uma unidade de conservação com objetivos de manejo e normas específicos, com o propósito de proporcionar os meios e as condições para que todos os objetivos da unidade possam ser alcançados de forma harmônica e eficaz;

XVII - plano de manejo: documento técnico mediante o qual, com fundamento nos objetivos gerais de uma unidade de conservação, se estabelece o seu zoneamento e as normas que devem presidir o uso da área e o manejo dos recursos naturais, inclusive a implantação das estruturas físicas necessárias à gestão da unidade;

XVIII - zona de amortecimento: o entorno de uma unidade de conservação, onde as atividades humanas estão sujeitas a normas e restrições específicas, com o propósito de minimizar os impactos negativos sobre a unidade; e

XIX - corredores ecológicos: porções de ecossistemas naturais ou seminaturais, ligando unidades de conservação, que possibilitam entre elas o fluxo de genes e o movimento da biota, facilitando a dispersão de espécies e a recolonização de áreas degradadas, bem como a manutenção de populações que demandam para sua sobrevivência áreas com extensão maior do que aquela das unidades individuais. 


\section{CAPÍTULO II \\ DO SISTEMA NACIONAL DE UNIDADES DE CONSERVAÇÃO \\ DA NATUREZA - SNUC}

Art. $3^{\underline{0}}$ O Sistema Nacional de Unidades de Conservação da Natureza - SNUC é constituído pelo conjunto das unidades de conservação federais, estaduais e municipais, de acordo com o disposto nesta Lei.

Art. $4^{\circ} \mathrm{O}$ SNUC tem os seguintes objetivos:

I - contribuir para a manutenção da diversidade biológica e dos recursos genéticos no território nacional e nas águas jurisdicionais;

II - proteger as espécies ameaçadas de extinção no âmbito regional e nacional;

III - contribuir para a preservação e a restauração da diversidade de ecossistemas naturais;

IV - promover o desenvolvimento sustentável a partir dos recursos naturais;

V - promover a utilização dos princípios e práticas de conservação da natureza no processo de desenvolvimento;

VI - proteger paisagens naturais e pouco alteradas de notável beleza cênica;

VII - proteger as características relevantes de natureza geológica, geomorfológica, espeleológica, arqueológica, paleontológica e cultural;

VIII - proteger e recuperar recursos hídricos e edáficos;

IX - recuperar ou restaurar ecossistemas degradados;

$\mathrm{X}$ - proporcionar meios e incentivos para atividades de pesquisa científica, estudos e monitoramento ambiental;

XI - valorizar econômica e socialmente a diversidade biológica;

XII - favorecer condições e promover a educação e interpretação ambiental, a recreação em contato com a natureza e o turismo ecológico;

XIII - proteger os recursos naturais necessários à subsistência de populações tradicionais, respeitando e valorizando seu conhecimento e sua cultura e promovendo-as social e economicamente.

Art. 5ํำ SNUC será regido por diretrizes que: 
I - assegurem que no conjunto das unidades de conservação estejam representadas amostras significativas e ecologicamente viáveis das diferentes populações, habitats e ecossistemas do território nacional e das águas jurisdicionais, salvaguardando o patrimônio biológico existente;

II - assegurem os mecanismos e procedimentos necessários ao envolvimento da sociedade no estabelecimento e na revisão da política nacional de unidades de conservação;

III - assegurem a participação efetiva das populações locais na criação, implantação e gestão das unidades de conservação;

IV - busquem o apoio e a cooperação de organizações não-governamentais, de organizações privadas e pessoas físicas para o desenvolvimento de estudos, pesquisas científicas, práticas de educação ambiental, atividades de lazer e de turismo ecológico, monitoramento, manutenção e outras atividades de gestão das unidades de conservação;

$\mathrm{V}$ - incentivem as populações locais e as organizações privadas a estabelecerem e administrarem unidades de conservação dentro do sistema nacional;

VI - assegurem, nos casos possíveis, a sustentabilidade econômica das unidades de conservação;

VII - permitam o uso das unidades de conservação para a conservação in situ de populações das variantes genéticas selvagens dos animais e plantas domesticados e recursos genéticos silvestres;

VIII - assegurem que o processo de criação e a gestão das unidades de conservação sejam feitos de forma integrada com as políticas de administração das terras e águas circundantes, considerando as condições e necessidades sociais e econômicas locais;

IX - considerem as condições e necessidades das populações locais no desenvolvimento e adaptação de métodos e técnicas de uso sustentável dos recursos naturais;

$X$ - garantam às populações tradicionais cuja subsistência dependa da utilização de recursos naturais existentes no interior das unidades de conservação meios de subsistência alternativos ou a justa indenização pelos recursos perdidos;

XI - garantam uma alocação adequada dos recursos financeiros necessários para que, uma vez criadas, as unidades de conservação possam ser geridas de forma eficaz e atender aos seus objetivos;

XII - busquem conferir às unidades de conservação, nos casos possíveis e respeitadas as conveniências da administração, autonomia administrativa e financeira; e

XIII - busquem proteger grandes áreas por meio de um conjunto integrado de unidades de conservação de diferentes categorias, próximas ou contíguas, e suas respectivas zonas de amortecimento e corredores ecológicos, integrando as diferentes atividades de preservação da natureza, uso sustentável dos recursos naturais e restauração e recuperação dos ecossistemas. 
Art. 6ํㅡㅇ O SNUC será gerido pelos seguintes órgãos, com as respectivas atribuições:

I - Órgão consultivo e deliberativo: o Conselho Nacional do Meio Ambiente - Conama, com as atribuições de acompanhar a implementação do Sistema;

II - Órgão central: o Ministério do Meio Ambiente, com a finalidade de coordenar o Sistema; e

III - Órgãos executores: o Instituto Brasileiro do Meio Ambiente e dos Recursos Naturais Renováveis - Ibama, os órgãos estaduais e municipais, com a função de implementar o SNUC, subsidiar as propostas de criação e administrar as unidades de conservação federais, estaduais e municipais, nas respectivas esferas de atuação. (Vide Medida Provisória nº 366, de 2007)

Parágrafo único. Podem integrar o SNUC, excepcionalmente e a critério do Conama, unidades de conservação estaduais e municipais que, concebidas para atender a peculiaridades regionais ou locais, possuam objetivos de manejo que não possam ser satisfatoriamente atendidos por nenhuma categoria prevista nesta Lei e cujas características permitam, em relação a estas, uma clara distinção.

\section{CAPÍTULO III \\ DAS CATEGORIAS DE UNIDADES DE CONSERVAÇÃO}

Art. $7^{0}$ As unidades de conservação integrantes do SNUC dividem-se em dois grupos, com características específicas:

I - Unidades de Proteção Integral;

II - Unidades de Uso Sustentável.

$\S 1^{\circ} \mathrm{O}$ objetivo básico das Unidades de Proteção Integral é preservar a natureza, sendo admitido apenas o uso indireto dos seus recursos naturais, com exceção dos casos previstos nesta Lei.

$\S 2^{\circ} \mathrm{O}$ objetivo básico das Unidades de Uso Sustentável é compatibilizar a conservação da natureza com o uso sustentável de parcela dos seus recursos naturais.

Art. $8^{0} \mathrm{O}$ grupo das Unidades de Proteção Integral é composto pelas seguintes categorias de unidade de conservação:

I - Estação Ecológica;

II - Reserva Biológica;

III - Parque Nacional;

IV - Monumento Natural;

V - Refúgio de Vida Silvestre. 
Art. 9ำ A Estação Ecológica tem como objetivo a preservação da natureza e a realização de pesquisas científicas.

$\S 1^{\mathrm{o}}$ A Estação Ecológica é de posse e domínio públicos, sendo que as áreas particulares incluídas em seus limites serão desapropriadas, de acordo com o que dispõe a lei.

$\S 2^{\mathrm{o}}$ É proibida a visitação pública, exceto quando com objetivo educacional, de acordo com o que dispuser o Plano de Manejo da unidade ou regulamento específico.

$\S 3^{0}$ A pesquisa científica depende de autorização prévia do órgão responsável pela administração da unidade e está sujeita às condições e restrições por este estabelecidas, bem como àquelas previstas em regulamento.

$\S 4^{\mathrm{o}} \mathrm{Na}$ Estação Ecológica só podem ser permitidas alterações dos ecossistemas no caso de:

I - medidas que visem a restauração de ecossistemas modificados;

II - manejo de espécies com o fim de preservar a diversidade biológica;

III - coleta de componentes dos ecossistemas com finalidades científicas;

IV - pesquisas científicas cujo impacto sobre o ambiente seja maior do que aquele causado pela simples observação ou pela coleta controlada de componentes dos ecossistemas, em uma área correspondente a no máximo três por cento da extensão total da unidade e até o limite de um mil e quinhentos hectares.

Art. 10. A Reserva Biológica tem como objetivo a preservação integral da biota e demais atributos naturais existentes em seus limites, sem interferência humana direta ou modificações ambientais, excetuando-se as medidas de recuperação de seus ecossistemas alterados e as ações de manejo necessárias para recuperar e preservar o equilíbrio natural, a diversidade biológica e os processos ecológicos naturais.

$\S 1^{\underline{o}}$ A Reserva Biológica é de posse e domínio públicos, sendo que as áreas particulares incluídas em seus limites serão desapropriadas, de acordo com o que dispõe a lei.

$\S 2^{\circ}$ É proibida a visitação pública, exceto aquela com objetivo educacional, de acordo com regulamento específico.

$\S 3^{0}$ A pesquisa científica depende de autorização prévia do órgão responsável pela administração da unidade e está sujeita às condições e restrições por este estabelecidas, bem como àquelas previstas em regulamento.

Art. 11. O Parque Nacional tem como objetivo básico a preservação de ecossistemas naturais de grande relevância ecológica e beleza cênica, possibilitando a realização de pesquisas científicas e o desenvolvimento de atividades de educação e interpretação ambiental, de recreação em contato com a natureza e de turismo ecológico. 
$\S 1^{\circ}$ O Parque Nacional é de posse e domínio públicos, sendo que as áreas particulares incluídas em seus limites serão desapropriadas, de acordo com o que dispõe a lei.

$\S 2^{0}$ A visitação pública está sujeita às normas e restrições estabelecidas no Plano de Manejo da unidade, às normas estabelecidas pelo órgão responsável por sua administração, e àquelas previstas em regulamento.

$\S 3^{0}$ A pesquisa científica depende de autorização prévia do órgão responsável pela administração da unidade e está sujeita às condições e restrições por este estabelecidas, bem como àquelas previstas em regulamento.

$\S 4^{\underline{0}}$ As unidades dessa categoria, quando criadas pelo Estado ou Município, serão denominadas, respectivamente, Parque Estadual e Parque Natural Municipal.

Art. 12. O Monumento Natural tem como objetivo básico preservar sítios naturais raros, singulares ou de grande beleza cênica.

$\S 1^{\underline{0}} \mathrm{O}$ Monumento Natural pode ser constituído por áreas particulares, desde que seja possível compatibilizar os objetivos da unidade com a utilização da terra e dos recursos naturais do local pelos proprietários.

$\S 2^{\underline{0}}$ Havendo incompatibilidade entre os objetivos da área e as atividades privadas ou não havendo aquiescência do proprietário às condições propostas pelo órgão responsável pela administração da unidade para a coexistência do Monumento Natural com o uso da propriedade, a área deve ser desapropriada, de acordo com o que dispõe a lei.

$\S 3^{0} \mathrm{~A}$ visitação pública está sujeita às condições e restrições estabelecidas no Plano de Manejo da unidade, às normas estabelecidas pelo órgão responsável por sua administração e àquelas previstas em regulamento.

Art. 13. O Refúgio de Vida Silvestre tem como objetivo proteger ambientes naturais onde se asseguram condições para a existência ou reprodução de espécies ou comunidades da flora local e da fauna residente ou migratória.

$\S 1^{\circ}$ O Refúgio de Vida Silvestre pode ser constituído por áreas particulares, desde que seja possível compatibilizar os objetivos da unidade com a utilização da terra e dos recursos naturais do local pelos proprietários.

$\S 2^{\underline{0}}$ Havendo incompatibilidade entre os objetivos da área e as atividades privadas ou não havendo aquiescência do proprietário às condições propostas pelo órgão responsável pela administração da unidade para a coexistência do Refúgio de Vida Silvestre com o uso da propriedade, a área deve ser desapropriada, de acordo com o que dispõe a lei.

$\S 3^{0} \mathrm{~A}$ visitação pública está sujeita às normas e restrições estabelecidas no Plano de Manejo da unidade, às normas estabelecidas pelo órgão responsável por sua administração, e àquelas previstas em regulamento. 
$\S 4^{\underline{0}}$ A pesquisa científica depende de autorização prévia do órgão responsável pela administração da unidade e está sujeita às condições e restrições por este estabelecidas, bem como àquelas previstas em regulamento.

Art. 14. Constituem o Grupo das Unidades de Uso Sustentável as seguintes categorias de unidade de conservação:

I - Área de Proteção Ambiental;

II - Área de Relevante Interesse Ecológico;

III - Floresta Nacional;

IV - Reserva Extrativista;

V - Reserva de Fauna;

VI - Reserva de Desenvolvimento Sustentável; e

VII - Reserva Particular do Patrimônio Natural.

Art. 15. A Área de Proteção Ambiental é uma área em geral extensa, com um certo grau de ocupação humana, dotada de atributos abióticos, bióticos, estéticos ou culturais especialmente importantes para a qualidade de vida e o bem-estar das populações humanas, e tem como objetivos básicos proteger a diversidade biológica, disciplinar o processo de ocupação e assegurar a sustentabilidade do uso dos recursos naturais.

$\S 1^{\text {o }}$ A Área de Proteção Ambiental é constituída por terras públicas ou privadas.

$\S 2^{\underline{0}}$ Respeitados os limites constitucionais, podem ser estabelecidas normas e restrições para a utilização de uma propriedade privada localizada em uma Área de Proteção Ambiental.

$\S 3^{0}$ As condições para a realização de pesquisa científica e visitação pública nas áreas sob domínio público serão estabelecidas pelo órgão gestor da unidade.

$\S 4^{\underline{0}}$ Nas áreas sob propriedade privada, cabe ao proprietário estabelecer as condições para pesquisa e visitação pelo público, observadas as exigências e restrições legais.

$\S 5^{0}$ A Área de Proteção Ambiental disporá de um Conselho presidido pelo órgão responsável por sua administração e constituído por representantes dos órgãos públicos, de organizações da sociedade civil e da população residente, conforme se dispuser no regulamento desta Lei.

Art. 16. A Área de Relevante Interesse Ecológico é uma área em geral de pequena extensão, com pouca ou nenhuma ocupação humana, com características naturais extraordinárias ou que abriga exemplares raros da biota regional, e tem como objetivo manter os ecossistemas naturais de 
importância regional ou local e regular o uso admissível dessas áreas, de modo a compatibilizá-lo com os objetivos de conservação da natureza.

$\S 1^{\circ}$ A Área de Relevante Interesse Ecológico é constituída por terras públicas ou privadas.

$\S 2^{0}$ Respeitados os limites constitucionais, podem ser estabelecidas normas e restrições para a utilização de uma propriedade privada localizada em uma Área de Relevante Interesse Ecológico.

Art. 17. A Floresta Nacional é uma área com cobertura florestal de espécies predominantemente nativas e tem como objetivo básico o uso múltiplo sustentável dos recursos florestais e a pesquisa científica, com ênfase em métodos para exploração sustentável de florestas nativas.

$\S 1^{\circ}$ A Floresta Nacional é de posse e domínio públicos, sendo que as áreas particulares incluídas em seus limites devem ser desapropriadas de acordo com o que dispõe a lei.

$\S 2^{0}$ Nas Florestas Nacionais é admitida a permanência de populações tradicionais que a habitam quando de sua criação, em conformidade com o disposto em regulamento e no Plano de Manejo da unidade.

$\S 3^{0} \mathrm{~A}$ visitação pública é permitida, condicionada às normas estabelecidas para o manejo da unidade pelo órgão responsável por sua administração.

$\S 4^{4^{0}} \mathrm{~A}$ pesquisa é permitida e incentivada, sujeitando-se à prévia autorização do órgão responsável pela administração da unidade, às condições e restrições por este estabelecidas e àquelas previstas em regulamento.

$\S 5^{0}$ A Floresta Nacional disporá de um Conselho Consultivo, presidido pelo órgão responsável por sua administração e constituído por representantes de órgãos públicos, de organizações da sociedade civil e, quando for o caso, das populações tradicionais residentes.

$\S 6^{\underline{0}}$ A unidade desta categoria, quando criada pelo Estado ou Município, será denominada, respectivamente, Floresta Estadual e Floresta Municipal.

Art. 18. A Reserva Extrativista é uma área utilizada por populações extrativistas tradicionais, cuja subsistência baseia-se no extrativismo e, complementarmente, na agricultura de subsistência e na criação de animais de pequeno porte, e tem como objetivos básicos proteger os meios de vida e a cultura dessas populações, e assegurar o uso sustentável dos recursos naturais da unidade.

$\S 1^{0}$ A Reserva Extrativista é de domínio público, com uso concedido às populações extrativistas tradicionais conforme o disposto no art. 23 desta Lei e em regulamentação específica, sendo que as áreas particulares incluídas em seus limites devem ser desapropriadas, de acordo com o que dispõe a lei.

$\S 2^{\underline{0}}$ A Reserva Extrativista será gerida por um Conselho Deliberativo, presidido pelo órgão responsável por sua administração e constituído por representantes de órgãos públicos, de 
organizações da sociedade civil e das populações tradicionais residentes na área, conforme se dispuser em regulamento e no ato de criação da unidade.

$\S 3^{0}$ A visitação pública é permitida, desde que compatível com os interesses locais e de acordo com o disposto no Plano de Manejo da área.

$\S 4^{0}$ A pesquisa científica é permitida e incentivada, sujeitando-se à prévia autorização do órgão responsável pela administração da unidade, às condições e restrições por este estabelecidas e às normas previstas em regulamento.

$\S 5^{\circ}$ O Plano de Manejo da unidade será aprovado pelo seu Conselho Deliberativo.

$\S 6^{0}$ São proibidas a exploração de recursos minerais e a caça amadorística ou profissional.

$\S 7^{0}$ A exploração comercial de recursos madeireiros só será admitida em bases sustentáveis e em situações especiais e complementares às demais atividades desenvolvidas na Reserva Extrativista, conforme o disposto em regulamento e no Plano de Manejo da unidade.

Art. 19. A Reserva de Fauna é uma área natural com populações animais de espécies nativas, terrestres ou aquáticas, residentes ou migratórias, adequadas para estudos técnico-científicos sobre o manejo econômico sustentável de recursos faunísticos.

$\S 1^{\text {o }}$ A Reserva de Fauna é de posse e domínio públicos, sendo que as áreas particulares incluídas em seus limites devem ser desapropriadas de acordo com o que dispõe a lei.

$\S 2^{0}$ A visitação pública pode ser permitida, desde que compatível com o manejo da unidade e de acordo com as normas estabelecidas pelo órgão responsável por sua administração.

$\S 3^{0}$ É proibido o exercício da caça amadorística ou profissional.

$\S 4^{\circ}$ A comercialização dos produtos e subprodutos resultantes das pesquisas obedecerá ao disposto nas leis sobre fauna e regulamentos.

Art. 20. A Reserva de Desenvolvimento Sustentável é uma área natural que abriga populações tradicionais, cuja existência baseia-se em sistemas sustentáveis de exploração dos recursos naturais, desenvolvidos ao longo de gerações e adaptados às condições ecológicas locais e que desempenham um papel fundamental na proteção da natureza e na manutenção da diversidade biológica.

$\S 1^{\underline{0}}$ A Reserva de Desenvolvimento Sustentável tem como objetivo básico preservar a natureza e, ao mesmo tempo, assegurar as condições e os meios necessários para a reprodução e a melhoria dos modos e da qualidade de vida e exploração dos recursos naturais das populações tradicionais, bem como valorizar, conservar e aperfeiçoar o conhecimento e as técnicas de manejo do ambiente, desenvolvido por estas populações. 
$\S 2^{\underline{o}}$ A Reserva de Desenvolvimento Sustentável é de domínio público, sendo que as áreas particulares incluídas em seus limites devem ser, quando necessário, desapropriadas, de acordo com o que dispõe a lei.

$\S 3^{0} \mathrm{O}$ uso das áreas ocupadas pelas populações tradicionais será regulado de acordo com o disposto no art. 23 desta Lei e em regulamentação específica.

$\S 4^{\circ}$ A Reserva de Desenvolvimento Sustentável será gerida por um Conselho Deliberativo, presidido pelo órgão responsável por sua administração e constituído por representantes de órgãos públicos, de organizações da sociedade civil e das populações tradicionais residentes na área, conforme se dispuser em regulamento e no ato de criação da unidade.

$\S 5^{\circ}$ As atividades desenvolvidas na Reserva de Desenvolvimento Sustentável obedecerão às seguintes condições:

I - é permitida e incentivada a visitação pública, desde que compatível com os interesses locais e de acordo com o disposto no Plano de Manejo da área;

II - é permitida e incentivada a pesquisa científica voltada à conservação da natureza, à melhor relação das populações residentes com seu meio e à educação ambiental, sujeitando-se à prévia autorização do órgão responsável pela administração da unidade, às condições e restrições por este estabelecidas e às normas previstas em regulamento;

III - deve ser sempre considerado o equilíbrio dinâmico entre o tamanho da população e a conservação; e

IV - é admitida a exploração de componentes dos ecossistemas naturais em regime de manejo sustentável e a substituição da cobertura vegetal por espécies cultiváveis, desde que sujeitas ao zoneamento, às limitações legais e ao Plano de Manejo da área.

$\S 6^{0}$ O Plano de Manejo da Reserva de Desenvolvimento Sustentável definirá as zonas de proteção integral, de uso sustentável e de amortecimento e corredores ecológicos, e será aprovado pelo Conselho Deliberativo da unidade.

Art. 21. A Reserva Particular do Patrimônio Natural é uma área privada, gravada com perpetuidade, com o objetivo de conservar a diversidade biológica.

$\S 1^{0} \mathrm{O}$ gravame de que trata este artigo constará de termo de compromisso assinado perante o órgão ambiental, que verificará a existência de interesse público, e será averbado à margem da inscrição no Registro Público de Imóveis.

$\S 2^{0}$ Só poderá ser permitida, na Reserva Particular do Patrimônio Natural, conforme se dispuser em regulamento:

I - a pesquisa científica; 
II - a visitação com objetivos turísticos, recreativos e educacionais;

III - (VETADO)

$\S 3^{0}$ Os órgãos integrantes do SNUC, sempre que possível e oportuno, prestarão orientação técnica e científica ao proprietário de Reserva Particular do Patrimônio Natural para a elaboração de um Plano de Manejo ou de Proteção e de Gestão da unidade.

\section{CAPÍTULO IV \\ DA CRIAÇÃO, IMPLANTAÇÃO E GESTÃO DAS UNIDADES DE CONSERVAÇÃO}

Art. 22. As unidades de conservação são criadas por ato do Poder Público.

\section{$\S 1^{\underline{0}} \underline{(\mathrm{VETADO})}$}

$\S 2^{\underline{0}}$ A criação de uma unidade de conservação deve ser precedida de estudos técnicos e de consulta pública que permitam identificar a localização, a dimensão e os limites mais adequados para a unidade, conforme se dispuser em regulamento.

$\S 3^{0}$ No processo de consulta de que trata o $\S 2^{0}$, o Poder Público é obrigado a fornecer informações adequadas e inteligíveis à população local e a outras partes interessadas.

$\S 4^{\circ} \mathrm{Na}$ criação de Estação Ecológica ou Reserva Biológica não é obrigatória a consulta de que trata o $\S 2^{\underline{o}}$ deste artigo.

$\S 5^{\circ}$ As unidades de conservação do grupo de Uso Sustentável podem ser transformadas total ou parcialmente em unidades do grupo de Proteção Integral, por instrumento normativo do mesmo nível hierárquico do que criou a unidade, desde que obedecidos os procedimentos de consulta estabelecidos no $\S 2^{\underline{0}}$ deste artigo.

$\S 6^{0} \mathrm{~A}$ ampliação dos limites de uma unidade de conservação, sem modificação dos seus limites originais, exceto pelo acréscimo proposto, pode ser feita por instrumento normativo do mesmo nível hierárquico do que criou a unidade, desde que obedecidos os procedimentos de consulta estabelecidos no $\S 2^{\underline{0}}$ deste artigo.

$\S 7^{0}$ A desafetação ou redução dos limites de uma unidade de conservação só pode ser feita mediante lei específica.

Art. 22-A. O Poder Público poderá, ressalvadas as atividades agropecuárias e outras atividades econômicas em andamento e obras públicas licenciadas, na forma da lei, decretar limitações administrativas provisórias ao exercício de atividades e empreendimentos efetiva ou potencialmente causadores de degradação ambiental, para a realização de estudos com vistas na criação de Unidade de Conservação, quando, a critério do órgão ambiental competente, houver risco de dano grave aos recursos naturais ali existentes. (Incluído pela Lei $\mathrm{n}^{\mathrm{o}} 11.132$, de 2005)

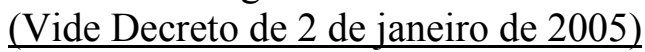


$\S 1^{\circ}$ Sem prejuízo da restrição e observada a ressalva constante do caput, na área submetida a limitações administrativas, não serão permitidas atividades que importem em exploração a corte raso da floresta e demais formas de vegetação nativa. (Incluído pela Lei ${ }^{\circ} 11.132$, de 2005)

$\S 2^{0}$ A destinação final da área submetida ao disposto neste artigo será definida no prazo de 7 (sete) meses, improrrogáveis, findo o qual fica extinta a limitação administrativa. (Incluído pela Lei $\mathrm{n}^{\mathrm{o}} 11.132$, de 2005)

Art. 23. A posse e o uso das áreas ocupadas pelas populações tradicionais nas Reservas Extrativistas e Reservas de Desenvolvimento Sustentável serão regulados por contrato, conforme se dispuser no regulamento desta Lei.

$\S 1^{\underline{0}}$ As populações de que trata este artigo obrigam-se a participar da preservação, recuperação, defesa e manutenção da unidade de conservação.

$\S 2^{0} \mathrm{O}$ uso dos recursos naturais pelas populações de que trata este artigo obedecerá às seguintes normas:

I - proibição do uso de espécies localmente ameaçadas de extinção ou de práticas que danifiquem os seus habitats;

II - proibição de práticas ou atividades que impeçam a regeneração natural dos ecossistemas;

III - demais normas estabelecidas na legislação, no Plano de Manejo da unidade de conservação e no contrato de concessão de direito real de uso.

Art. 24. O subsolo e o espaço aéreo, sempre que influírem na estabilidade do ecossistema, integram os limites das unidades de conservação.

Art. 25. As unidades de conservação, exceto Área de Proteção Ambiental e Reserva Particular do Patrimônio Natural, devem possuir uma zona de amortecimento e, quando conveniente, corredores ecológicos.

$\S 1^{0} \mathrm{O}$ órgão responsável pela administração da unidade estabelecerá normas específicas regulamentando a ocupação e o uso dos recursos da zona de amortecimento e dos corredores ecológicos de uma unidade de conservação.

$\S 2^{0}$ Os limites da zona de amortecimento e dos corredores ecológicos e as respectivas normas de que trata o $\S 1^{\underline{o}}$ poderão ser definidas no ato de criação da unidade ou posteriormente.

Art. 26. Quando existir um conjunto de unidades de conservação de categorias diferentes ou não, próximas, justapostas ou sobrepostas, e outras áreas protegidas públicas ou privadas, constituindo um mosaico, a gestão do conjunto deverá ser feita de forma integrada e participativa, considerando-se os seus distintos objetivos de conservação, de forma a compatibilizar a presença da biodiversidade, a valorização da sociodiversidade e o desenvolvimento sustentável no contexto regional. 
Parágrafo único. O regulamento desta Lei disporá sobre a forma de gestão integrada do conjunto das unidades.

Art. 27. As unidades de conservação devem dispor de um Plano de Manejo.

$\S 1^{\circ}$ O Plano de Manejo deve abranger a área da unidade de conservação, sua zona de amortecimento e os corredores ecológicos, incluindo medidas com o fim de promover sua integração à vida econômica e social das comunidades vizinhas.

$\S 2^{0} \mathrm{Na}$ elaboração, atualização e implementação do Plano de Manejo das Reservas Extrativistas, das Reservas de Desenvolvimento Sustentável, das Áreas de Proteção Ambiental e, quando couber, das Florestas Nacionais e das Áreas de Relevante Interesse Ecológico, será assegurada a ampla participação da população residente.

$\S 3^{0}$ O Plano de Manejo de uma unidade de conservação deve ser elaborado no prazo de cinco anos a partir da data de sua criação.

$\S 4^{\underline{0}} \S 4^{\underline{0}}$ O Plano de Manejo poderá dispor sobre as atividades de liberação planejada e cultivo de organismos geneticamente modificados nas Áreas de Proteção Ambiental e nas zonas de amortecimento das demais categorias de unidade de conservação, observadas as informações contidas na decisão técnica da Comissão Técnica Nacional de Biossegurança - CTNBio sobre:

I - o registro de ocorrência de ancestrais diretos e parentes silvestres;

II - as características de reprodução, dispersão e sobrevivência do organismo geneticamente modificado;

III - o isolamento reprodutivo do organismo geneticamente modificado em relação aos seus ancestrais diretos e parentes silvestres; e

IV - situações de risco do organismo geneticamente modificado à biodiversidade. (Redação dada pela Lei $n^{\circ} 11.460$, de 2007) (Vide Medida Provisória n ${ }^{0} 327$, de 2006).

Art. 28. São proibidas, nas unidades de conservação, quaisquer alterações, atividades ou modalidades de utilização em desacordo com os seus objetivos, o seu Plano de Manejo e seus regulamentos.

Parágrafo único. Até que seja elaborado o Plano de Manejo, todas as atividades e obras desenvolvidas nas unidades de conservação de proteção integral devem se limitar àquelas destinadas a garantir a integridade dos recursos que a unidade objetiva proteger, assegurando-se às populações tradicionais porventura residentes na área as condições e os meios necessários para a satisfação de suas necessidades materiais, sociais e culturais.

Art. 29. Cada unidade de conservação do grupo de Proteção Integral disporá de um Conselho Consultivo, presidido pelo órgão responsável por sua administração e constituído por representantes de órgãos públicos, de organizações da sociedade civil, por proprietários de terras 
localizadas em Refúgio de Vida Silvestre ou Monumento Natural, quando for o caso, e, na hipótese prevista no $\S 2^{\underline{0}}$ do art. 42 , das populações tradicionais residentes, conforme se dispuser em regulamento e no ato de criação da unidade.

Art. 30. As unidades de conservação podem ser geridas por organizações da sociedade civil de interesse público com objetivos afins aos da unidade, mediante instrumento a ser firmado com o órgão responsável por sua gestão.

Art. 31. É proibida a introdução nas unidades de conservação de espécies não autóctones.

$\S 1^{\circ}$ Excetuam-se do disposto neste artigo as Áreas de Proteção Ambiental, as Florestas Nacionais, as Reservas Extrativistas e as Reservas de Desenvolvimento Sustentável, bem como os animais e plantas necessários à administração e às atividades das demais categorias de unidades de conservação, de acordo com o que se dispuser em regulamento e no Plano de Manejo da unidade.

$\S 2^{\circ}$ Nas áreas particulares localizadas em Refúgios de Vida Silvestre e Monumentos Naturais podem ser criados animais domésticos e cultivadas plantas considerados compatíveis com as finalidades da unidade, de acordo com o que dispuser o seu Plano de Manejo.

Art. 32. Os órgãos executores articular-se-ão com a comunidade científica com o propósito de incentivar o desenvolvimento de pesquisas sobre a fauna, a flora e a ecologia das unidades de conservação e sobre formas de uso sustentável dos recursos naturais, valorizando-se o conhecimento das populações tradicionais.

$\S 1^{\circ}$ As pesquisas científicas nas unidades de conservação não podem colocar em risco a sobrevivência das espécies integrantes dos ecossistemas protegidos.

$\S 2^{0}$ A realização de pesquisas científicas nas unidades de conservação, exceto Área de Proteção Ambiental e Reserva Particular do Patrimônio Natural, depende de aprovação prévia e está sujeita à fiscalização do órgão responsável por sua administração.

$\S 3^{0}$ Os órgãos competentes podem transferir para as instituições de pesquisa nacionais, mediante acordo, a atribuição de aprovar a realização de pesquisas científicas e de credenciar pesquisadores para trabalharem nas unidades de conservação.

Art. 33. A exploração comercial de produtos, subprodutos ou serviços obtidos ou desenvolvidos a partir dos recursos naturais, biológicos, cênicos ou culturais ou da exploração da imagem de unidade de conservação, exceto Área de Proteção Ambiental e Reserva Particular do Patrimônio Natural, dependerá de prévia autorização e sujeitará o explorador a pagamento, conforme disposto em regulamento.

Art. 34. Os órgãos responsáveis pela administração das unidades de conservação podem receber recursos ou doações de qualquer natureza, nacionais ou internacionais, com ou sem encargos, provenientes de organizações privadas ou públicas ou de pessoas físicas que desejarem colaborar com a sua conservação. 
Parágrafo único. A administração dos recursos obtidos cabe ao órgão gestor da unidade, e estes serão utilizados exclusivamente na sua implantação, gestão e manutenção.

Art. 35. Os recursos obtidos pelas unidades de conservação do Grupo de Proteção Integral mediante a cobrança de taxa de visitação e outras rendas decorrentes de arrecadação, serviços e atividades da própria unidade serão aplicados de acordo com os seguintes critérios:

I - até cinqüenta por cento, e não menos que vinte e cinco por cento, na implementação, manutenção e gestão da própria unidade;

II - até cinqüenta por cento, e não menos que vinte e cinco por cento, na regularização fundiária das unidades de conservação do Grupo;

III - até cinqüenta por cento, e não menos que quinze por cento, na implementação, manutenção e gestão de outras unidades de conservação do Grupo de Proteção Integral.

Art. 36. Nos casos de licenciamento ambiental de empreendimentos de significativo impacto ambiental, assim considerado pelo órgão ambiental competente, com fundamento em estudo de impacto ambiental e respectivo relatório - EIA/RIMA, o empreendedor é obrigado a apoiar a implantação e manutenção de unidade de conservação do Grupo de Proteção Integral, de acordo com o disposto neste artigo e no regulamento desta Lei.

$\S 1^{\circ} \mathrm{O}$ montante de recursos a ser destinado pelo empreendedor para esta finalidade não pode ser inferior a meio por cento dos custos totais previstos para a implantação do empreendimento, sendo o percentual fixado pelo órgão ambiental licenciador, de acordo com o grau de impacto ambiental causado pelo empreendimento.

$\S 2^{\mathrm{o}}$ Ao órgão ambiental licenciador compete definir as unidades de conservação a serem beneficiadas, considerando as propostas apresentadas no EIA/RIMA e ouvido o empreendedor, podendo inclusive ser contemplada a criação de novas unidades de conservação.

$\S 3^{\mathrm{o}}$ Quando o empreendimento afetar unidade de conservação específica ou sua zona de amortecimento, o licenciamento a que se refere o caput deste artigo só poderá ser concedido mediante autorização do órgão responsável por sua administração, e a unidade afetada, mesmo que não pertencente ao Grupo de Proteção Integral, deverá ser uma das beneficiárias da compensação definida neste artigo.

\section{CAPÍTULO V \\ DOS INCENTIVOS, ISENÇÕES E PENALIDADES}

\section{Art. 37. (VETADO)}

Art. 38. A ação ou omissão das pessoas físicas ou jurídicas que importem inobservância aos preceitos desta Lei e a seus regulamentos ou resultem em dano à flora, à fauna e aos demais atributos naturais das unidades de conservação, bem como às suas instalações e às zonas de amortecimento e corredores ecológicos, sujeitam os infratores às sanções previstas em lei. 
Art. 39. Dê-se ao art. 40 da Lei $\mathrm{n}^{0} 9.605$, de 12 de fevereiro de 1998 , a seguinte redação:

"Art. 40. (VETADO)

"§ $1^{0}$ Entende-se por Unidades de Conservação de Proteção Integral as Estações Ecológicas, as Reservas Biológicas, os Parques Nacionais, os Monumentos Naturais e os Refúgios de Vida Silvestre." (NR)

"§ $2^{\underline{0}}$ A ocorrência de dano afetando espécies ameaçadas de extinção no interior das Unidades de Conservação de Proteção Integral será considerada circunstância agravante para a fixação da pena." (NR)

$" \S 3^{\circ}$ $" 1$

Art. 40. Acrescente-se à Lei ${ }^{\circ}{ }^{9}$.605, de 1998, o seguinte art. 40-A:

"Art. 40-A. (VETADO)

"§ $1^{0}$ Entende-se por Unidades de Conservação de Uso Sustentável as Áreas de Proteção Ambiental, as Áreas de Relevante Interesse Ecológico, as Florestas Nacionais, as Reservas Extrativistas, as Reservas de Fauna, as Reservas de Desenvolvimento Sustentável e as Reservas Particulares do Patrimônio Natural." (AC)

"§ $2^{0}$ A ocorrência de dano afetando espécies ameaçadas de extinção no interior das Unidades de Conservação de Uso Sustentável será considerada circunstância agravante para a fixação da pena." (AC)

"§ $3^{\circ}$ Se o crime for culposo, a pena será reduzida à metade." (AC)

\section{CAPÍTULO VI \\ DAS RESERVAS DA BIOSFERA}

Art. 41. A Reserva da Biosfera é um modelo, adotado internacionalmente, de gestão integrada, participativa e sustentável dos recursos naturais, com os objetivos básicos de preservação da diversidade biológica, o desenvolvimento de atividades de pesquisa, o monitoramento ambiental, a educação ambiental, o desenvolvimento sustentável e a melhoria da qualidade de vida das populações.

$\S 1^{\underline{0}}$ A Reserva da Biosfera é constituída por:

I - uma ou várias áreas-núcleo, destinadas à proteção integral da natureza;

II - uma ou várias zonas de amortecimento, onde só são admitidas atividades que não resultem em dano para as áreas-núcleo; e 
III - uma ou várias zonas de transição, sem limites rígidos, onde o processo de ocupação e o manejo dos recursos naturais são planejados e conduzidos de modo participativo e em bases sustentáveis.

$\S 2^{\underline{0}}$ A Reserva da Biosfera é constituída por áreas de domínio público ou privado.

$\S 3^{0}$ A Reserva da Biosfera pode ser integrada por unidades de conservação já criadas pelo Poder Público, respeitadas as normas legais que disciplinam o manejo de cada categoria específica.

$\S 4^{0}$ A Reserva da Biosfera é gerida por um Conselho Deliberativo, formado por representantes de instituições públicas, de organizações da sociedade civil e da população residente, conforme se dispuser em regulamento e no ato de constituição da unidade.

$\S 5^{-}$A Reserva da Biosfera é reconhecida pelo Programa Intergovernamental "O Homem e a Biosfera-MAB", estabelecido pela Unesco, organização da qual o Brasil é membro.

\section{CAPÍTULO VII \\ DAS DISPOSIÇÕES GERAIS E TRANSITÓRIAS}

Art. 42. As populações tradicionais residentes em unidades de conservação nas quais sua permanência não seja permitida serão indenizadas ou compensadas pelas benfeitorias existentes e devidamente realocadas pelo Poder Público, em local e condições acordados entre as partes.

$\S 1^{\circ}$ O Poder Público, por meio do órgão competente, priorizará o reassentamento das populações tradicionais a serem realocadas.

$\S 2^{\underline{0}}$ Até que seja possível efetuar o reassentamento de que trata este artigo, serão estabelecidas normas e ações específicas destinadas a compatibilizar a presença das populações tradicionais residentes com os objetivos da unidade, sem prejuízo dos modos de vida, das fontes de subsistência e dos locais de moradia destas populações, assegurando-se a sua participação na elaboração das referidas normas e ações.

$\S 3^{\circ} \mathrm{Na}$ hipótese prevista no $\S 2^{\circ}$, as normas regulando o prazo de permanência e suas condições serão estabelecidas em regulamento.

Art. 43. O Poder Público fará o levantamento nacional das terras devolutas, com o objetivo de definir áreas destinadas à conservação da natureza, no prazo de cinco anos após a publicação desta Lei.

Art. 44. As ilhas oceânicas e costeiras destinam-se prioritariamente à proteção da natureza e sua destinação para fins diversos deve ser precedida de autorização do órgão ambiental competente.

Parágrafo único. Estão dispensados da autorização citada no caput os órgãos que se utilizam das citadas ilhas por força de dispositivos legais ou quando decorrente de compromissos legais assumidos. 
Art. 45. Excluem-se das indenizações referentes à regularização fundiária das unidades de conservação, derivadas ou não de desapropriação:

\section{I - (VETADO)}

\section{II - (VETADO)}

III - as espécies arbóreas declaradas imunes de corte pelo Poder Público;

IV - expectativas de ganhos e lucro cessante;

V - o resultado de cálculo efetuado mediante a operação de juros compostos;

VI - as áreas que não tenham prova de domínio inequívoco e anterior à criação da unidade.

Art. 46. A instalação de redes de abastecimento de água, esgoto, energia e infra-estrutura urbana em geral, em unidades de conservação onde estes equipamentos são admitidos depende de prévia aprovação do órgão responsável por sua administração, sem prejuízo da necessidade de elaboração de estudos de impacto ambiental e outras exigências legais.

Parágrafo único. Esta mesma condição se aplica à zona de amortecimento das unidades do Grupo de Proteção Integral, bem como às áreas de propriedade privada inseridas nos limites dessas unidades e ainda não indenizada.

Art. 47. O órgão ou empresa, público ou privado, responsável pelo abastecimento de água ou que faça uso de recursos hídricos, beneficiário da proteção proporcionada por uma unidade de conservação, deve contribuir financeiramente para a proteção e implementação da unidade, de acordo com o disposto em regulamentação específica.

Art. 48. O órgão ou empresa, público ou privado, responsável pela geração e distribuição de energia elétrica, beneficiário da proteção oferecida por uma unidade de conservação, deve contribuir financeiramente para a proteção e implementação da unidade, de acordo com o disposto em regulamentação específica.

Art. 49. A área de uma unidade de conservação do Grupo de Proteção Integral é considerada zona rural, para os efeitos legais.

Parágrafo único. A zona de amortecimento das unidades de conservação de que trata este artigo, uma vez definida formalmente, não pode ser transformada em zona urbana.

Art. 50. O Ministério do Meio Ambiente organizará e manterá um Cadastro Nacional de Unidades de Conservação, com a colaboração do Ibama e dos órgãos estaduais e municipais competentes.

$\S 1^{\underline{0}}$ O Cadastro a que se refere este artigo conterá os dados principais de cada unidade de conservação, incluindo, dentre outras características relevantes, informações sobre espécies 
ameaçadas de extinção, situação fundiária, recursos hídricos, clima, solos e aspectos socioculturais e antropológicos.

$\S 2^{\circ} \mathrm{O}$ Ministério do Meio Ambiente divulgará e colocará à disposição do público interessado os dados constantes do Cadastro.

Art. 51. O Poder Executivo Federal submeterá à apreciação do Congresso Nacional, a cada dois anos, um relatório de avaliação global da situação das unidades de conservação federais do País.

Art. 52. Os mapas e cartas oficiais devem indicar as áreas que compõem o SNUC.

Art. 53. O Ibama elaborará e divulgará periodicamente uma relação revista e atualizada das espécies da flora e da fauna ameaçadas de extinção no território brasileiro.

Parágrafo único. O Ibama incentivará os competentes órgãos estaduais e municipais a elaborarem relações equivalentes abrangendo suas respectivas áreas de jurisdição.

Art. 54. O Ibama, excepcionalmente, pode permitir a captura de exemplares de espécies ameaçadas de extinção destinadas a programas de criação em cativeiro ou formação de coleções científicas, de acordo com o disposto nesta Lei e em regulamentação específica.

Art. 55. As unidades de conservação e áreas protegidas criadas com base nas legislações anteriores e que não pertençam às categorias previstas nesta Lei serão reavaliadas, no todo ou em parte, no prazo de até dois anos, com o objetivo de definir sua destinação com base na categoria e função para as quais foram criadas, conforme o disposto no regulamento desta Lei.

\section{Art. 56. (VETADO)}

Art. 57. Os órgãos federais responsáveis pela execução das políticas ambiental e indigenista deverão instituir grupos de trabalho para, no prazo de cento e oitenta dias a partir da vigência desta Lei, propor as diretrizes a serem adotadas com vistas à regularização das eventuais superposições entre áreas indígenas e unidades de conservação.

Parágrafo único. No ato de criação dos grupos de trabalho serão fixados os participantes, bem como a estratégia de ação e a abrangência dos trabalhos, garantida a participação das comunidades envolvidas.

Art. 57-A. O Poder Executivo estabelecerá os limites para o plantio de organismos geneticamente modificados nas áreas que circundam as unidades de conservação até que seja fixada sua zona de amortecimento e aprovado o seu respectivo Plano de Manejo.

Parágrafo único. O disposto no caput deste artigo não se aplica às Áreas de Proteção Ambiental e Reservas de Particulares do Patrimônio Nacional. (Redação dada pela Lei $n^{\circ} 11.460$, de 2007) Regulamento. (Vide Medida Provisória n ${ }^{\circ} 327$, de 2006). 
Art. 58. O Poder Executivo regulamentará esta Lei, no que for necessário à sua aplicação, no prazo de cento e oitenta dias a partir da data de sua publicação.

Art. 59. Esta Lei entra em vigor na data de sua publicação.

Art. 60. Revogam-se os arts. $5^{\circ}$ e $6^{\circ}$ da Lei $\mathrm{n}^{\circ} 4.771$, de 15 de setembro de 1965 ; o art. $5^{\circ}$ da Lei

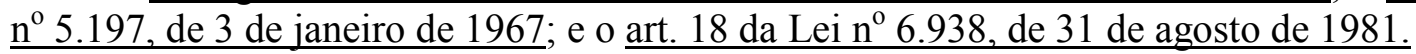

Brasília, 18 de julho de 2000; 179º da Independência e $112^{\circ}$ da República.

MARCO ANTONIO DE OLIVEIRA MACIEL

José Sarney Filho

Este texto não substitui o publicado no D.O.U. de 19.7.2000 


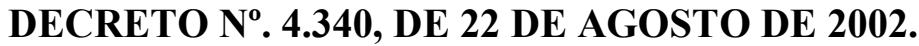

Regulamenta artigos da Lei $\mathbf{n}^{\mathbf{0}} \mathbf{9 . 9 8 5}$, de 18 de julho de 2000, que dispõe sobre o Sistema Nacional de Unidades de Conservação da Natureza - SNUC, e dá outras providências. O PRESIDENTE DA REPÚBLICA, no uso das atribuições que lhe conferem o art. 84, inciso IV, e o art. 225, $\S 1$, incisos I, II, III e VII, da Constituição Federal, e tendo em vista o disposto na Lei $n^{\circ} .9 .985$, de 18 de julho de 2000 ,

\section{E C R E T A:}

Art. $1^{\circ}$ Este Decreto regulamenta os arts. 22, 24, 25, 26, 27, 29, 30, 33, 36, 41, 42, 47, 48 e 55 da Lei $\mathrm{n}^{\mathrm{o}} .9 .985$, de 18 de julho de 2000 , bem como os arts. $15,17,18$ e 20 , no que concerne aos conselhos das unidades de conservação.

\section{CAPÍTULO I \\ DA CRIAÇÃO DE UNIDADE DE CONSERVAÇÃO}

Art. $2^{\circ} \mathrm{O}$ ato de criação de uma unidade de conservação deve indicar:

I - a denominação, a categoria de manejo, os objetivos, os limites, a área da unidade e o órgão responsável por sua administração;

II - a população tradicional beneficiária, no caso das Reservas Extrativistas e das Reservas de Desenvolvimento Sustentável;

III - a população tradicional residente, quando couber, no caso das Florestas Nacionais, Florestas Estaduais ou Florestas Municipais; e

IV - as atividades econômicas, de segurança e de defesa nacional envolvidas.

Art. $3^{\circ}$ A denominação de cada unidade de conservação deverá basear-se, preferencialmente, na sua característica natural mais significativa, ou na sua denominação mais antiga, dando-se prioridade, neste último caso, às designações indígenas ancestrais.

Art. $4^{\circ}$ Compete ao órgão executor proponente de nova unidade de conservação elaborar os estudos técnicos preliminares e realizar, quando for o caso, a consulta pública e os demais procedimentos administrativos necessários à criação da unidade.

Art. $5^{\circ}$ A consulta pública para a criação de unidade de conservação tem a finalidade de subsidiar a definição da localização, da dimensão e dos limites mais adequados para a unidade.

$\S 1^{\mathrm{o}}$ A consulta consiste em reuniões públicas ou, a critério do órgão ambiental competente, outras formas de oitiva da população local e de outras partes interessadas.

$\S 2^{\circ}$ No processo de consulta pública, o órgão executor competente deve indicar, de modo claro e em linguagem acessível, as implicações para a população residente no interior e no entorno da unidade proposta. 


\section{CAPÍTULO II \\ DO SUBSOLO E DO ESPAÇO AÉREO}

Art. $6^{\circ}$ Os limites da unidade de conservação, em relação ao subsolo, são estabelecidos:

I - no ato de sua criação, no caso de Unidade de Conservação de Proteção Integral; e

II - no ato de sua criação ou no Plano de Manejo, no caso de Unidade de Conservação de Uso

Sustentável.

Art. $7^{\circ}$ Os limites da unidade de conservação, em relação ao espaço aéreo, são estabelecidos no Plano de Manejo, embasados em estudos técnicos realizados pelo órgão gestor da unidade de conservação, consultada a autoridade aeronáutica competente e de acordo com a legislação vigente.

\section{CAPÍTULO III \\ DO MOSAICO DE UNIDADES DE CONSERVAÇÃO}

Art. $8^{\circ} \mathrm{O}$ mosaico de unidades de conservação será reconhecido em ato do Ministério do Meio Ambiente, a pedido dos órgãos gestores das unidades de conservação.

Art. $9^{\circ} \mathrm{O}$ mosaico deverá dispor de um conselho de mosaico, com caráter consultivo e a função de atuar como instância de gestão integrada das unidades de conservação que o compõem.

$\S 1^{\circ}$ A composição do conselho de mosaico é estabelecida na portaria que institui o mosaico e deverá obedecer aos mesmos critérios estabelecidos no Capítulo V deste Decreto.

$\S 2^{\circ} \mathrm{O}$ conselho de mosaico terá como presidente um dos chefes das unidades de conservação que o compõem, o qual será escolhido pela maioria simples de seus membros.

Art. 10. Compete ao conselho de cada mosaico:

I - elaborar seu regimento interno, no prazo de noventa dias, contados da sua instituição;

II - propor diretrizes e ações para compatibilizar, integrar e otimizar:

a) as atividades desenvolvidas em cada unidade de conservação, tendo em vista, especialmente:

1. os usos na fronteira entre unidades;

2. o acesso às unidades;

3. a fiscalização;

4. o monitoramento e avaliação dos Planos de Manejo;

5. a pesquisa científica; e

6. a alocação de recursos advindos da compensação referente ao licenciamento ambiental de empreendimentos com significativo impacto ambiental;

b) a relação com a população residente na área do mosaico;

III - manifestar-se sobre propostas de solução para a sobreposição de unidades; e IV - manifestar-se, quando provocado por órgão executor, por conselho de unidade de conservação ou por outro órgão do Sistema Nacional do Meio Ambiente - SISNAMA, sobre assunto de interesse para a gestão do mosaico.

Art. 11. Os corredores ecológicos, reconhecidos em ato do Ministério do Meio Ambiente, integram os mosaicos para fins de sua gestão.

Parágrafo único. $\mathrm{Na}$ ausência de mosaico, o corredor ecológico que interliga unidades de conservação terá o mesmo tratamento da sua zona de amortecimento. 


\section{CAPÍTULO IV DO PLANO DE MANEJO}

Art. 12. O Plano de Manejo da unidade de conservação, elaborado pelo órgão gestor ou pelo proprietário quando for o caso, será aprovado:

I - em portaria do órgão executor, no caso de Estação Ecológica, Reserva Biológica, Parque Nacional, Monumento Natural, Refúgio de Vida Silvestre, Área de Proteção Ambiental, Área de Relevante Interesse Ecológico, Floresta Nacional, Reserva de Fauna e Reserva Particular do Patrimônio Natural;

II - em resolução do conselho deliberativo, no caso de Reserva Extrativista e Reserva de Desenvolvimento Sustentável, após prévia aprovação do órgão executor.

Art. 13. O contrato de concessão de direito real de uso e o termo de compromisso firmados com populações tradicionais das Reservas Extrativistas e Reservas de Uso Sustentável devem estar de acordo com o Plano de Manejo, devendo ser revistos, se necessário.

Art. 14. Os órgãos executores do Sistema Nacional de Unidades de Conservação da Natureza SNUC, em suas respectivas esferas de atuação, devem estabelecer, no prazo de cento e oitenta dias, a partir da publicação deste Decreto, roteiro metodológico básico para a elaboração dos Planos de Manejo das diferentes categorias de unidades de conservação, uniformizando conceitos e metodologias, fixando diretrizes para o diagnóstico da unidade, zoneamento, programas de manejo, prazos de avaliação e de revisão e fases de implementação.

Art. 15. A partir da criação de cada unidade de conservação e até que seja estabelecido o Plano de Manejo, devem ser formalizadas e implementadas ações de proteção e fiscalização.

Art. 16. O Plano de Manejo aprovado deve estar disponível para consulta do público na sede da unidade de conservação e no centro de documentação do órgão executor.

\section{CAPÍTULO V \\ DO CONSELHO}

Art. 17. As categorias de unidade de conservação poderão ter, conforme a Lei $n^{\circ} 9.985$, de 2000 , conselho consultivo ou deliberativo, que serão presididos pelo chefe da unidade de conservação, o qual designará os demais conselheiros indicados pelos setores a serem representados.

$\S 1^{\circ} \mathrm{A}$ representação dos órgãos públicos deve contemplar, quando couber, os órgãos ambientais dos três níveis da Federação e órgãos de áreas afins, tais como pesquisa científica, educação, defesa nacional, cultura, turismo, paisagem, arquitetura, arqueologia e povos indígenas e assentamentos agrícolas.

$\S 2^{\circ}$ A representação da sociedade civil deve contemplar, quando couber, a comunidade científica e organizações não-governamentais ambientalistas com atuação comprovada na região da unidade, população residente e do entorno, população tradicional, proprietários de imóveis no interior da unidade, trabalhadores e setor privado atuantes na região e representantes dos Comitês de Bacia Hidrográfica. 
$\S 3^{\circ}$ A representação dos órgãos públicos e da sociedade civil nos conselhos deve ser, sempre que possível, paritária, considerando as peculiaridades regionais.

$\S 4^{\circ}$ A Organização da Sociedade Civil de Interesse Público - OSCIP com representação no conselho de unidade de conservação não pode se candidatar à gestão de que trata o Capítulo VI deste Decreto.

$\S 5^{\circ} \mathrm{O}$ mandato do conselheiro é de dois anos, renovável por igual período, não remunerado e considerado atividade de relevante interesse público.

$\S 6^{\circ}$ No caso de unidade de conservação municipal, o Conselho Municipal de Defesa do Meio Ambiente, ou órgão equivalente, cuja composição obedeça ao disposto neste artigo, e com competências que incluam aquelas especificadas no art. 20 deste Decreto, pode ser designado como conselho da unidade de conservação.

Art. 18. A reunião do conselho da unidade de conservação deve ser pública, com pauta preestabelecida no ato da convocação e realizada em local de fácil acesso.

Art. 19. Compete ao órgão executor:

I - convocar o conselho com antecedência mínima de sete dias;

II - prestar apoio à participação dos conselheiros nas reuniões, sempre que solicitado e devidamente justificado.

Parágrafo único. O apoio do órgão executor indicado no inciso II não restringe aquele que possa ser prestado por outras organizações.

Art. 20. Compete ao conselho de unidade de conservação:

I - elaborar o seu regimento interno, no prazo de noventa dias, contados da sua instalação;

II - acompanhar a elaboração, implementação e revisão do Plano de Manejo da unidade de conservação, quando couber, garantindo o seu caráter participativo;

III - buscar a integração da unidade de conservação com as demais unidades e espaços territoriais especialmente protegidos e com o seu entorno;

IV - esforçar-se para compatibilizar os interesses dos diversos segmentos sociais relacionados com a unidade;

V - avaliar o orçamento da unidade e o relatório financeiro anual elaborado pelo órgão executor em relação aos objetivos da unidade de conservação;

VI - opinar, no caso de conselho consultivo, ou ratificar, no caso de conselho deliberativo, a contratação e os dispositivos do termo de parceria com OSCIP, na hipótese de gestão compartilhada da unidade;

VII - acompanhar a gestão por OSCIP e recomendar a rescisão do termo de parceria, quando constatada irregularidade;

VIII - manifestar-se sobre obra ou atividade potencialmente causadora de impacto na unidade de conservação, em sua zona de amortecimento, mosaicos ou corredores ecológicos; e

IX - propor diretrizes e ações para compatibilizar, integrar e otimizar a relação com a população do entorno ou do interior da unidade, conforme o caso. 


\section{CAPÍTULO VI \\ DA GESTÃO COMPARTILHADA COM OSCIP}

Art. 21. A gestão compartilhada de unidade de conservação por OSCIP é regulada por termo de parceria firmado com o órgão executor, nos termos da Lei n ${ }^{\circ}$ 9.790, de 23 de março de 1999.

Art. 22. Poderá gerir unidade de conservação a OSCIP que preencha os seguintes requisitos:

I - tenha dentre seus objetivos institucionais a proteção do meio ambiente ou a promoção do desenvolvimento sustentável; e

II - comprove a realização de atividades de proteção do meio ambiente ou desenvolvimento sustentável, preferencialmente na unidade de conservação ou no mesmo bioma.

Art. 23. O edital para seleção de OSCIP, visando a gestão compartilhada, deve ser publicado com no mínimo sessenta dias de antecedência, em jornal de grande circulação na região da unidade de conservação e no Diário Oficial, nos termos da Lei nº 8.666, de 21 de junho de 1993.

Parágrafo único. Os termos de referência para a apresentação de proposta pelas OSCIP serão definidos pelo órgão executor, ouvido o conselho da unidade.

Art. 24. A OSCIP deve encaminhar anualmente relatórios de suas atividades para apreciação do órgão executor e do conselho da unidade.

\section{CAPÍTULO VII \\ DA AUTORIZAÇÃO PARA A EXPLORAÇÃO DE BENS E SERVIÇOS}

Art. 25. É passível de autorização a exploração de produtos, sub-produtos ou serviços inerentes às unidades de conservação, de acordo com os objetivos de cada categoria de unidade.

Parágrafo único. Para os fins deste Decreto, entende-se por produtos, sub-produtos ou serviços inerentes à unidade de conservação:

I - aqueles destinados a dar suporte físico e logístico à sua administração e à implementação das atividades de uso comum do público, tais como visitação, recreação e turismo;

II - a exploração de recursos florestais e outros recursos naturais em Unidades de Conservação de Uso Sustentável, nos limites estabelecidos em lei.

Art. 26. A partir da publicação deste Decreto, novas autorizações para a exploração comercial de produtos, sub-produtos ou serviços em unidade de conservação de domínio público só serão permitidas se previstas no Plano de Manejo, mediante decisão do órgão executor, ouvido o conselho da unidade de conservação.

Art. 27. O uso de imagens de unidade de conservação com finalidade comercial será cobrado conforme estabelecido em ato administrativo pelo órgão executor.

Parágrafo único. Quando a finalidade do uso de imagem da unidade de conservação for preponderantemente científica, educativa ou cultural, o uso será gratuito.

Art. 28. No processo de autorização da exploração comercial de produtos, sub-produtos ou serviços de unidade de conservação, o órgão executor deve viabilizar a participação de pessoas 
físicas ou jurídicas, observando-se os limites estabelecidos pela legislação vigente sobre licitações públicas e demais normas em vigor.

Art. 29. A autorização para exploração comercial de produto, sub-produto ou serviço de unidade de conservação deve estar fundamentada em estudos de viabilidade econômica e investimentos elaborados pelo órgão executor, ouvido o conselho da unidade.

Art. 30. Fica proibida a construção e ampliação de benfeitoria sem autorização do órgão gestor da unidade de conservação.

\section{CAPÍTULO VIII \\ DA COMPENSAÇÃO POR SIGNIFICATIVO IMPACTO AMBIENTAL}

Art. 31. Para os fins de fixação da compensação ambiental de que trata o art. 36 da Lei ${ }^{\circ}$ 9.985, de 2000, o órgão ambiental licenciador estabelecerá o grau de impacto a partir dos estudos ambientais realizados quando do processo de licenciamento ambiental, sendo considerados os impactos negativos, não mitigáveis e passíveis de riscos que possam comprometer a qualidade de vida de uma região ou causar danos aos recursos naturais.

Parágrafo único. Os percentuais serão fixados, gradualmente, a partir de meio por cento dos custos totais previstos para a implantação do empreendimento, considerando-se a amplitude dos impactos gerados, conforme estabelecido no caput.

Art. 32. Será instituída no âmbito dos órgãos licenciadores câmaras de compensação ambiental, compostas por representantes do órgão, com a finalidade de analisar e propor a aplicação da compensação ambiental, para a aprovação da autoridade competente, de acordo com os estudos ambientais realizados e percentuais definidos.

Art. 33. A aplicação dos recursos da compensação ambiental de que trata o art. 36 da Lei ${ }^{\circ}$ 9.985, de 2000, nas unidades de conservação, existentes ou a serem criadas, deve obedecer à seguinte ordem de prioridade:

I - regularização fundiária e demarcação das terras;

II - elaboração, revisão ou implantação de plano de manejo;

III - aquisição de bens e serviços necessários à implantação, gestão, monitoramento e proteção da unidade, compreendendo sua área de amortecimento;

IV - desenvolvimento de estudos necessários à criação de nova unidade de conservação; e

$\mathrm{V}$ - desenvolvimento de pesquisas necessárias para o manejo da unidade de conservação e área de amortecimento.

Parágrafo único. Nos casos de Reserva Particular do Patrimônio Natural, Monumento Natural, Refúgio de Vida Silvestre, Área de Relevante Interesse Ecológico e Área de Proteção Ambiental, quando a posse e o domínio não sejam do Poder Público, os recursos da compensação somente poderão ser aplicados para custear as seguintes atividades:

I - elaboração do Plano de Manejo ou nas atividades de proteção da unidade;

II - realização das pesquisas necessárias para o manejo da unidade, sendo vedada a aquisição de bens e equipamentos permanentes;

III - implantação de programas de educação ambiental; e

IV - financiamento de estudos de viabilidade econômica para uso sustentável dos recursos naturais da unidade afetada. 
Art. 34. Os empreendimentos implantados antes da edição deste Decreto e em operação sem as respectivas licenças ambientais deverão requerer, no prazo de doze meses a partir da publicação deste Decreto, a regularização junto ao órgão ambiental competente mediante licença de operação corretiva ou retificadora.

\section{CAPÍTULO IX \\ DO REASSENTAMENTO DAS POPULAÇÕES TRADICIONAIS}

Art. 35. O processo indenizatório de que trata o art. 42 da Lei $n^{\circ} 9.985$, de 2000, respeitará o modo de vida e as fontes de subsistência das populações tradicionais.

Art. 36. Apenas as populações tradicionais residentes na unidade no momento da sua criação terão direito ao reassentamento.

Art. 37. O valor das benfeitorias realizadas pelo Poder Público, a título de compensação, na área de reassentamento será descontado do valor indenizatório.

Art. 38. O órgão fundiário competente, quando solicitado pelo órgão executor, deve apresentar, no prazo de seis meses, a contar da data do pedido, programa de trabalho para atender às demandas de reassentamento das populações tradicionais, com definição de prazos e condições para a sua realização.

Art. 39. Enquanto não forem reassentadas, as condições de permanência das populações tradicionais em Unidade de Conservação de Proteção Integral serão reguladas por termo de compromisso, negociado entre o órgão executor e as populações, ouvido o conselho da unidade de conservação.

$\S 1^{\circ} \mathrm{O}$ termo de compromisso deve indicar as áreas ocupadas, as limitações necessárias para assegurar a conservação da natureza e os deveres do órgão executor referentes ao processo indenizatório, assegurados o acesso das populações às suas fontes de subsistência e a conservação dos seus modos de vida.

$\S 2^{\circ} \mathrm{O}$ termo de compromisso será assinado pelo órgão executor e pelo representante de cada família, assistido, quando couber, pela comunidade rural ou associação legalmente constituída.

$\S 3^{\circ} \mathrm{O}$ termo de compromisso será assinado no prazo máximo de um ano após a criação da unidade de conservação e, no caso de unidade já criada, no prazo máximo de dois anos contado da publicação deste Decreto.

$\S 4^{\circ} \mathrm{O}$ prazo e as condições para o reassentamento das populações tradicionais estarão definidos no termo de compromisso.

\section{CAPÍTULO X \\ DA REAVALIAÇÃO DE UNIDADE DE CONSERVAÇÃO DE CATEGORIA NÃO PREVISTA NO SISTEMA}

Art. 40. A reavaliação de unidade de conservação prevista no art. 55 da Lei $n^{\circ} .9 .985$, de 2000, será feita mediante ato normativo do mesmo nível hierárquico que a criou.

Parágrafo único. $\mathrm{O}$ ato normativo de reavaliação será proposto pelo órgão executor. 


\section{CAPÍTULO XI DAS RESERVAS DA BIOSFERA}

Art. 41. A Reserva da Biosfera é um modelo de gestão integrada, participativa e sustentável dos recursos naturais, que tem por objetivos básicos a preservação da biodiversidade e o desenvolvimento das atividades de pesquisa científica, para aprofundar o conhecimento dessa diversidade biológica, o monitoramento ambiental, a educação ambiental, o desenvolvimento sustentável e a melhoria da qualidade de vida das populações.

Art. 42. O gerenciamento das Reservas da Biosfera será coordenado pela Comissão Brasileira para o Programa "O Homem e a Biosfera" - COBRAMAB, de que trata o Decreto de 21 de setembro de 1999, com a finalidade de planejar, coordenar e supervisionar as atividades relativas ao Programa.

Art. 43. Cabe à COBRAMAB, além do estabelecido no Decreto de 21 de setembro de 1999, apoiar a criação e instalar o sistema de gestão de cada uma das Reservas da Biosfera reconhecidas no Brasil.

$\S 1^{\circ}$ Quando a Reserva da Biosfera abranger o território de apenas um Estado, o sistema de gestão será composto por um conselho deliberativo e por comitês regionais.

$\S 2^{\circ}$ Quando a Reserva da Biosfera abranger o território de mais de um Estado, o sistema de gestão será composto por um conselho deliberativo e por comitês estaduais. $\S 3^{\circ}$ À COBRAMAB compete criar e coordenar a Rede Nacional de Reservas da Biosfera.

Art. 44. Compete aos conselhos deliberativos das Reservas da Biosfera:

I - aprovar a estrutura do sistema de gestão de sua Reserva e coordená-lo;

II - propor à COBRAMAB macro-diretrizes para a implantação das Reservas da Biosfera;

III - elaborar planos de ação da Reserva da Biosfera, propondo prioridades, metodologias, cronogramas, parcerias e áreas temáticas de atuação, de acordo como os objetivos básicos enumerados no art. 41 da Lei $n^{\circ}$. 9.985, de 2000;

IV - reforçar a implantação da Reserva da Biosfera pela proposição de projetos pilotos em pontos estratégicos de sua área de domínio; e

V - implantar, nas áreas de domínio da Reserva da Biosfera, os princípios básicos constantes do art. 41 da Lei $n^{\circ} 9.985$, de 2000.

Art. 45. Compete aos comitês regionais e estaduais:

I - apoiar os governos locais no estabelecimento de políticas públicas relativas às Reservas da Biosfera; e

II - apontar áreas prioritárias e propor estratégias para a implantação das Reservas da Biosfera, bem como para a difusão de seus conceitos e funções.

\section{CAPÍTULO XII \\ DAS DISPOSIÇÕES FINAIS}

Art. 46. Cada categoria de unidade de conservação integrante do SNUC será objeto de regulamento específico. 
Parágrafo único. O Ministério do Meio Ambiente deverá propor regulamentação de cada categoria de unidade de conservação, ouvidos os órgãos executores.

Art. 47. Este Decreto entra em vigor na data da sua publicação.

Art. 48. Fica revogado o Decreto $\mathrm{n}^{\mathrm{o}} 3.834$, de 5 de junho de 2001.

Brasília, 22 de agosto de $2002 ; 181^{\circ}$ da Independência e $114^{\circ}$ da República.

FERNANDO HENRIQUE CARDOSO

José Carlos Carvalho 


\section{RESOLUÇÃO No. 307, DE 5 DE JULHO DE 2002.}

Estabelece diretrizes, critérios e procedimentos para a gestão dos resíduos da construção civil.

O CONSELHO NACIONAL DO MEIO AMBIENTE-CONAMA, no uso das competências que lhe foram conferidas pela Lei $\mathrm{n}^{0}$ 6.938, de 31 de agosto de 1981, regulamentada pelo Decreto $\mathrm{n}^{\circ}$ 99.274, de 6 de julho de 1990, e tendo em vista o disposto em seu Regimento Interno, Anexo à Portaria n ${ }^{0}$ 326, de 15 de dezembro de 1994, e

Considerando a política urbana de pleno desenvolvimento da função social da cidade e da propriedade urbana, conforme disposto na Lei $\mathrm{n}^{0} 10.257$, de 10 de julho de 2001; Considerando a necessidade de implementação de diretrizes para a efetiva redução dos impactos ambientais gerados pelos resíduos oriundos da construção civil; Considerando que a disposição de resíduos da construção civil em locais inadequados contribui para a degradação da qualidade ambiental;

Considerando que os resíduos da construção civil representam um significativo percentual dos resíduos sólidos produzidos nas áreas urbanas;

Considerando que os geradores de resíduos da construção civil devem ser responsáveis pelos resíduos das atividades de construção, reforma, reparos e demolições de estruturas e estradas, bem como por aqueles resultantes da remoção de vegetação e escavação de solos;

Considerando a viabilidade técnica e econômica de produção e uso de materiais provenientes da reciclagem de resíduos da construção civil; e

Considerando que a gestão integrada de resíduos da construção civil deverá proporcionar benefícios de ordem social, econômica e ambiental, resolve:

Art. $1^{\mathrm{o}}$ Estabelecer diretrizes, critérios e procedimentos para a gestão dos resíduos da construção civil, disciplinando as ações necessárias de forma a minimizar os impactos ambientais.

Art. $2^{\text {o }}$ Para efeito desta Resolução, são adotadas as seguintes definições: I - Resíduos da construção civil: são os provenientes de construções, reformas, reparos e demolições de obras de construção civil, e os resultantes da preparação e da escavação de terrenos, tais como: tijolos, blocos cerâmicos, concreto em geral, solos, rochas, metais, resinas, colas, tintas, madeiras e compensados, forros, argamassa, gesso, telhas, pavimento asfáltico, vidros, plásticos, tubulações, fiação elétrica etc., comumente chamados de entulhos de obras, caliça ou metralha; II - Geradores: são pessoas, físicas ou jurídicas, públicas ou privadas, responsáveis por atividades ou empreendimentos que gerem os resíduos definidos nesta Resolução;

III - Transportadores: são as pessoas, físicas ou jurídicas, encarregadas da coleta e do transporte dos resíduos entre as fontes geradoras e as áreas de destinação; IV - Agregado reciclado: é o material granular proveniente do beneficiamento de resíduos de construção que apresentem características técnicas para a aplicação em obras de edificação, de infra-estrutura, em aterros sanitários ou outras obras de engenharia; V - Gerenciamento de resíduos: é o sistema de gestão que visa reduzir, reutilizar ou reciclar resíduos, incluindo planejamento, responsabilidades, práticas, procedimentos e recursos para 
desenvolver e implementar as ações necessárias ao cumprimento das etapas previstas em programas e planos;

VI - Reutilização: é o processo de reaplicação de um resíduo, sem transformação do mesmo; VII - Reciclagem: é o processo de reaproveitamento de um resíduo, após ter sido submetido à transformação;

VIII - Beneficiamento: é o ato de submeter um resíduo à operações e/ou processos que tenham por objetivo dotá-los de condições que permitam que sejam utilizados como matéria-prima ou produto;

IX - Aterro de resíduos da construção civil: é a área onde serão empregadas técnicas de disposição de resíduos da construção civil Classe "A" no solo, visando a reservação de materiais segregados de forma a possibilitar seu uso futuro e/ou futura utilização da área, utilizando princípios de engenharia para confiná-los ao menor volume possível, sem causar danos à saúde pública e ao meio ambiente;

X - Áreas de destinação de resíduos: são áreas destinadas ao beneficiamento ou à disposição final de resíduos.

Art. $3^{\circ}$ Os resíduos da construção civil deverão ser classificados, para efeito desta Resolução, da seguinte forma:

I - Classe A - são os resíduos reutilizáveis ou recicláveis como agregados, tais como: a) de construção, demolição, reformas e reparos de pavimentação e de outras obras de infraestrutura, inclusive solos provenientes de terraplanagem;

b) de construção, demolição, reformas e reparos de edificações: componentes cerâmicos (tijolos, blocos, telhas, placas de revestimento etc.), argamassa e concreto; c) de processo de fabricação e/ou demolição de peças pré-moldadas em concreto (blocos, tubos, meios-fios etc.) produzidas nos canteiros de obras; II - Classe B - são os resíduos recicláveis para outras destinações, tais como: plásticos, papel/papelão, metais, vidros, madeiras e outros;

III - Classe C - são os resíduos para os quais não foram desenvolvidas tecnologias ou aplicações economicamente viáveis que permitam a sua reciclagem/recuperação, tais como os produtos oriundos do gesso;

IV - Classe D - são os resíduos perigosos oriundos do processo de construção, tais como: tintas, solventes, óleos e outros, ou aqueles contaminados oriundos de demolições, reformas e reparos de clínicas radiológicas, instalações industriais e outros.

Art. $4^{\circ}$ Os geradores deverão ter como objetivo prioritário a não geração de resíduos e, secundariamente, a redução, a reutilização, a reciclagem e a destinação final. $\S 1^{\circ}$ Os resíduos da construção civil não poderão ser dispostos em aterros de resíduos domiciliares, em áreas de "bota fora", em encostas, corpos d’água, lotes vagos e em áreas protegidas por Lei, obedecidos os prazos definidos no art. 13 desta Resolução. $\S 2^{\circ}$ Os resíduos deverão ser destinados de acordo com o disposto no art. 10 desta Resolução.

Art. $5^{\circ}$ É instrumento para a implementação da gestão dos resíduos da construção civil o Plano Integrado de Gerenciamento de Resíduos da Construção Civil, a ser elaborado pelos Municípios 
e pelo Distrito Federal, o qual deverá incorporar:

I - Programa Municipal de Gerenciamento de Resíduos da Construção Civil; e II - Projetos de Gerenciamento de Resíduos da Construção Civil.

Art. $6^{\circ}$ Deverão constar do Plano Integrado de Gerenciamento de Resíduos da Construção Civil: I - as diretrizes técnicas e procedimentos para o Programa Municipal de Gerenciamento de Resíduos da Construção Civil e para os Projetos de Gerenciamento de Resíduos da Construção Civil a serem elaborados pelos grandes geradores, possibilitando o exercício das responsabilidades de todos os geradores.

II - o cadastramento de áreas, públicas ou privadas, aptas para recebimento, triagem e armazenamento temporário de pequenos volumes, em conformidade com o porte da área urbana municipal, possibilitando a destinação posterior dos resíduos oriundos de pequenos geradores às áreas de beneficiamento;

III - o estabelecimento de processos de licenciamento para as áreas de beneficiamento e de disposição final de resíduos;

IV - a proibição da disposição dos resíduos de construção em áreas não licenciadas; $\mathrm{V}$ - o incentivo à reinserção dos resíduos reutilizáveis ou reciclados no ciclo produtivo; VI - a definição de critérios para o cadastramento de transportadores;

VII - as ações de orientação, de fiscalização e de controle dos agentes envolvidos;

VIII - as ações educativas visando reduzir a geração de resíduos e possibilitar a sua segregação.

Art. $7^{\circ}$ O Programa Municipal de Gerenciamento de Resíduos da Construção Civil será elaborado, implementado e coordenado pelos municípios e pelo Distrito Federal, e deverá estabelecer diretrizes técnicas e procedimentos para o exercício das responsabilidades dos pequenos geradores, em conformidade com os critérios técnicos do sistema de limpeza urbana local.

Art. $8^{\circ}$ Os Projetos de Gerenciamento de Resíduos da Construção Civil serão elaborados e implementados pelos geradores não enquadrados no artigo anterior e terão como objetivo estabelecer os procedimentos necessários para o manejo e destinação ambientalmente adequados dos resíduos.

$\S 1^{\circ}$ O Projeto de Gerenciamento de Resíduos da Construção Civil, de empreendimentos e atividades não enquadrados na legislação como objeto de licenciamento ambiental, deverá ser apresentado juntamente com o projeto do empreendimento para análise pelo órgão competente do poder público municipal, em conformidade com o Programa Municipal de Gerenciamento de Resíduos da Construção Civil.

$\S 2^{\circ}$ O Projeto de Gerenciamento de Resíduos da Construção Civil de atividades e empreendimentos sujeitos ao licenciamento ambiental, deverá ser analisado dentro do processo de licenciamento, junto ao órgão ambiental competente.

Art. $9^{\circ}$ Os Projetos de Gerenciamento de Resíduos da Construção Civil deverão contemplar as seguintes etapas: 
I - caracterização: nesta etapa o gerador deverá identificar e quantificar os resíduos; II - triagem: deverá ser realizada, preferencialmente, pelo gerador na origem, ou ser realizada nas áreas de destinação licenciadas para essa finalidade, respeitadas as classes de resíduos estabelecidas no art. $3^{\circ}$ desta Resolução;

III - acondicionamento: o gerador deve garantir o confinamento dos resíduos após a geração até a etapa de transporte, assegurando em todos os casos em que seja possível, as condições de reutilização e de reciclagem;

IV - transporte: deverá ser realizado em conformidade com as etapas anteriores e de acordo com as normas técnicas vigentes para o transporte de resíduos;

V - destinação: deverá ser prevista de acordo com o estabelecido nesta Resolução.

Art. 10. Os resíduos da construção civil deverão ser destinados das seguintes formas: I - Classe A: deverão ser reutilizados ou reciclados na forma de agregados, ou encaminhados a áreas de aterro de resíduos da construção civil, sendo dispostos de modo a permitir a sua utilização ou reciclagem futura;

II - Classe B: deverão ser reutilizados, reciclados ou encaminhados a áreas de armazenamento temporário, sendo dispostos de modo a permitir a sua utilização ou reciclagem futura;

III - Classe C: deverão ser armazenados, transportados e destinados em conformidade com as normas técnicas específicas.

IV - Classe D: deverão ser armazenados, transportados, reutilizados e destinados em conformidade com as normas técnicas específicas.

Art. 11. Fica estabelecido o prazo máximo de doze meses para que os municípios e o Distrito Federal elaborem seus Planos Integrados de Gerenciamento de Resíduos de Construção Civil, contemplando os Programas Municipais de Gerenciamento de Resíduos de Construção Civil oriundos de geradores de pequenos volumes, e o prazo máximo de dezoito meses para sua implementação.

Art. 12. Fica estabelecido o prazo máximo de vinte e quatro meses para que os geradores, não enquadrados no art. $7^{\circ}$, incluam os Projetos de Gerenciamento de Resíduos da Construção Civil nos projetos de obras a serem submetidos à aprovação ou ao licenciamento dos órgãos competentes, conforme $\S \S 1^{\circ}$ e $2^{\circ}$ do art. $8^{\circ}$ Art. 13. No prazo máximo de dezoito meses os Municípios e o Distrito Federal deverão cessar a disposição de resíduos de construção civil em aterros de resíduos domiciliares e em áreas de "bota fora".

Art. 14. Esta Resolução entra em vigor em 2 de janeiro de 2003.

JOSÉ CARLOS CARVALHO

Presidente do Conselho

Publicada DOU 17/07/2002 